\title{
WestVirginiaUniversity
}

THE RESEARCH REPOSITORY @ WVU

West Virginia Agricultural and Forestry Experiment

Davis College of Agriculture, Natural Resources

Station Bulletins

And Design

$1-1-1980$

\section{Horse flies and deer flies of West Virginia : an illustrated key (Diptera, Tabanidae)}

Bastiaan M. Drees

Linda Butler

Follow this and additional works at: https://researchrepository.wvu.edu/ wv_agricultural_and_forestry_experiment_station_bulletins

\section{Digital Commons Citation}

Drees, Bastiaan M. and Butler, Linda, "Horse flies and deer flies of West Virginia : an illustrated key (Diptera, Tabanidae)" (1980). West Virginia Agricultural and Forestry Experiment Station Bulletins. 674.

https://researchrepository.wvu.edu/wv_agricultural_and_forestry_experiment_station_bulletins/571 @ WVU. It has been accepted for inclusion in West Virginia Agricultural and Forestry Experiment Station Bulletins by an authorized administrator of

The Research Repository @WVU. For more information, please contact ian.harmon@mail.wvu.edu. 


\section{Horse Flies and Deer Flies of}

\section{West Virginia: \\ An Illustrated Key \\ (Diptera, Tabanidae)}

Bulletin 674 June 1980
West Virginia University

Agricultural and Forestry Experiment Station

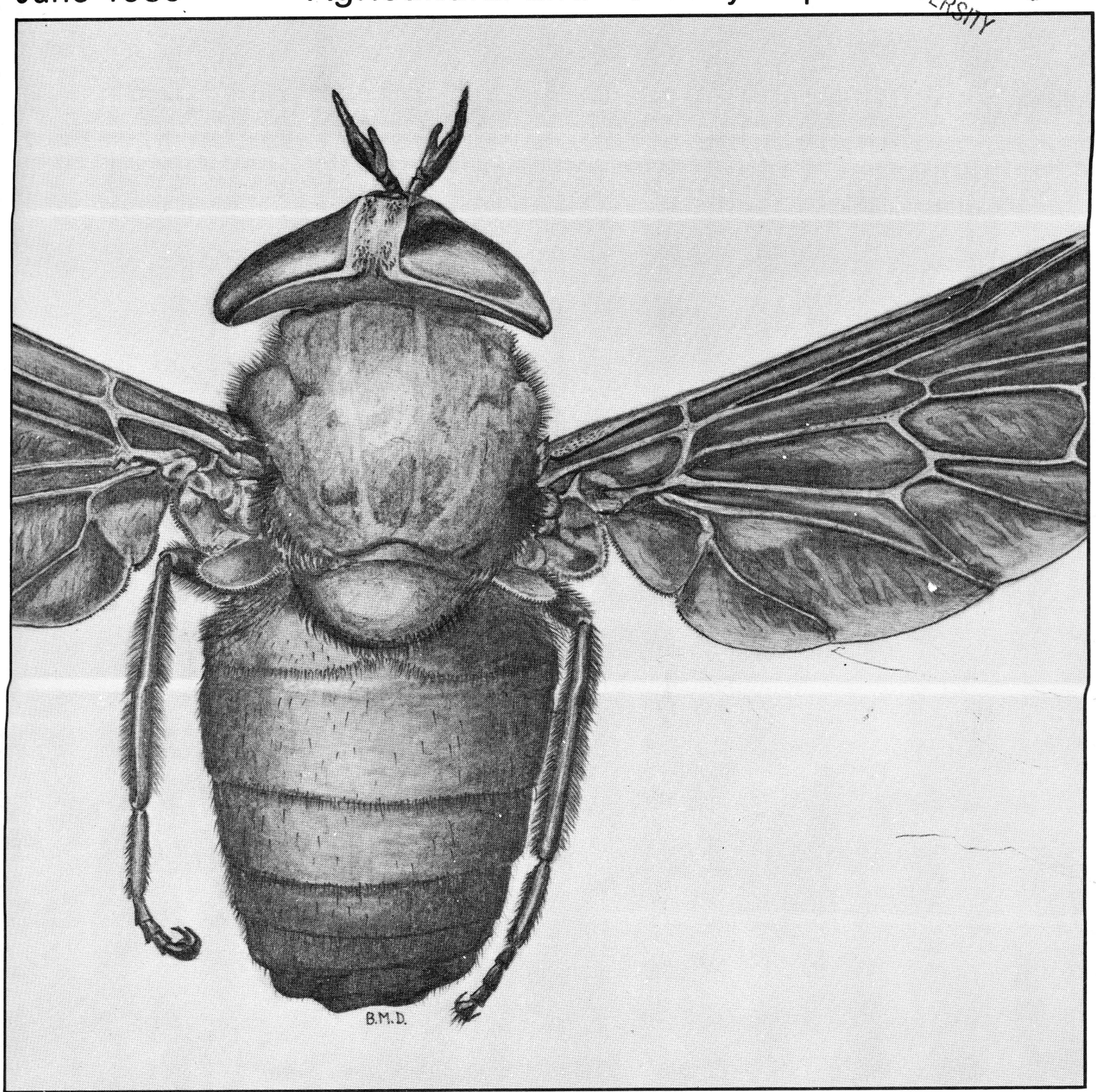


[Blank Page in Original Bulletin] 


\section{Horse Flies and Deer Flies of West Virginia: An Illustrated Key (Diptera, Tabanidae)}

Bastiaan M. Drees

Linda Butler

L. L. Pechuman 


\begin{abstract}
Intensive collection of Tabanidae was conducted throughout West Virginia from 1975 through 1978. These recon plus those previously published and those recorded from specimens in various private and institutional collections. now account for a total of 68 species and sub-species in nine genera known for the state. Collection data and keys are givenio these species, plus an additional 52 species that may eventually be taken in West Virginia.
\end{abstract}

\title{
ACKNOWLEDGMENTS
}

The authors are sincerely grateful to all those individuals who have contributed their specimens and collectir records of tabanids during the course of this study. Particularly, we wish to thank Jan D. Hacker of the West Virgini Department of Agriculture and his WVDA co-workers who provided invaluable collection assistance. Also we expras appreciation to the West Virginia University graduate students and staff in entomology from 1975-1978 for their interat and contributions to this project.

The illustrations for this publication could not have taken on their final form without the support and facilities at the Acarology Laboratory, Ohio State University, under the direction of Dr. D. E. Johnson. We are grateful also to the curators of the Ohio State University entomological collection for providing specimens for illustration.

West Virginia University

Agricultural and Forestry Experiment Station

College of Agriculture and Forestry

Dale W. Zinn, Director

Morgantown 


\section{CONTENTS}

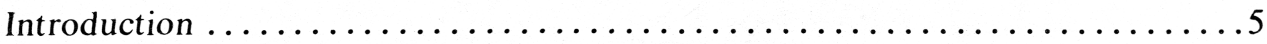

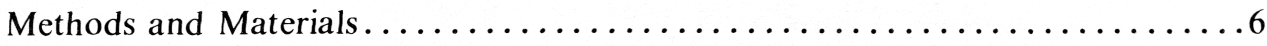

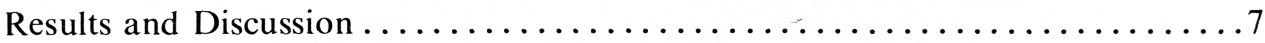

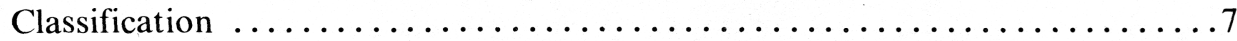

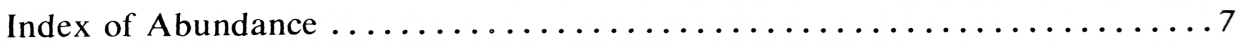

Taxonomy, Distribution and Habits $\ldots \ldots \ldots \ldots \ldots \ldots \ldots \ldots \ldots \ldots \ldots \ldots \ldots \ldots$

Key to Genera of West Virginia Tabanidae $\ldots \ldots \ldots \ldots \ldots \ldots \ldots \ldots \ldots \ldots \ldots \ldots \ldots$

Key to Species of West Virginia Chrysops ..................... 17

Key to Species of West Virginia Atylotus ...................... 38

Key to Species of West Virginia Hybomitra ....................... 39

Key to Species of West Virginia Tabanus ..................... 45

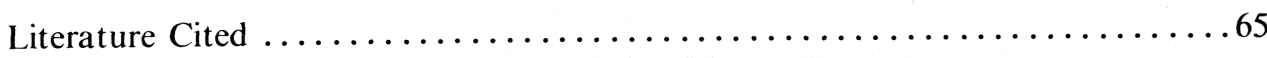




\section{THE AUTHORS}

Bastiaan M. Drees is in the Department of Entomology, Ohio State University; Linda Butler is Professor and Experiment Station Entomologist, West Virginia University; and L. L. Pechuman is Professor of Entomology, Cornell University. 


\title{
Horse Flies and Deer Flies of West Virginia: An Illustrated Key (Diptera, Tabanidae)
}

\author{
Bastiaan M. Drees, Linda Butler, and L. L. Pechuman
}

\section{INTRODUCTION}

Horse flies and deer flies of the dipterous family Tabanidae are important haematophagous insects. Adult feding habits present a problem to man and animals ince these flies often approach noisily and bite viciously. Several tabanid species have also been shown to transmit diseases mechanically from sick animals to healthy ones. Because of the importance of tabanids, most states have devoted some effort to becoming familiar with them. This is a necessary step in recognizing problem areas and the need for control. Until recently the tabanid fauna of West Virginia had virtually been ignored.

Most tabanid literature can be classed as systematic or biological, but many statewide and regional surveys include various mixtures of both. Major taxonomic works on adult Tabanidae include those by Brennan (1935), Stone (1938), Mackerras (1954), Philip (1941, 1965), and Fairchild (1969). Teskey (1969) summarized the available taxonomic information for the known abanid larvae in the eastern United States. Immature stages of many tabanids found in West Virginia were described by Goodwin (1972, 1973a, b, c, 1976a), Roberts and Dicke (1974), Tidwell (1973), Tidwell and Tidwell (1973), and Teskey and Burger (1976). The systematic listing employed here includes recent additions by Pechuman (1974) and Pechuman and Teskey (1967), and is in agreement with the unpublished check list of Pechuman (1975).

Although no comprehensive work includes all aspects of tabanid biology, much information was compiled by Hine (1906), Webb and Wells (1924), Philip (1928, 1931), Stone (1930), Schwardt (1936), Tashiro and Schwardt (1949, 1953a, b), Frost (1953), and Anthony (1960). General texts (Chvala et al., 1972; Oldroyd, 1964) often include extensive sections on tabanid biology. However, the biology and behavior of many tabanid species have not been described, and thus an effort has been made to include observations noted during the course of this study.

Tabanids are known vectors of many diseases (Chvala et al., 1972; Howell et al., 1941; Knowlton and Rowe, 1934; Krinsky, 1976; Stein et al., 1942; Philip, 1931; Stone, 1938; and James and Harwood, 1969). In the opinion of Woodson (pers. com.) of the West Virginia University Division of Animal and Veterinary Sciences, biting flies, including tabanids, are the primary vectors of anaplasmosis of cattle in West Virginia. In 1975 the United States Department of Agriculture tested 12,604 horses in West Virginia for equine infectious anemia.
Forty-one positive tests were reported (USDA, 1975). This disease was shown by Stein et al., (1942) to be transmitted by Tabanus sulcifrons, the stable fly, Stomoxy's calcitrans (L.), and by injection of infected blood into a healthy animal. They concluded that horse flies transmit disease more readily than stable flies due to the greater size of the mouthparts.

In addition to transmitting disease, Tabanidae are of considerable importance for the annoyance and blood loss produced by their feeding activities (Philip, 1931; Stone, 1938; Tashiro and Schwardt, 1949, 1953b; Jones and Anthony, 1964; Webb and Wells, 1924). Unfortunately, computation of economic losses resulting from the summation of tabanid activity is very difficult. Various estimates have related lowered milk production (Philip, 1931) and weight loss or mortality to the feeding activities of the female flies. Other insects may be attracted to the open wounds resulting from tabanid feeding, increasing the possibility of secondary bacterial infections or fly maggot infestations (Stone, 1938). Roberts et al. (1969) found eye gnats, which may be vectors of conjunctivitis, yaws, and bovine mastitis, to be attracted to tabanid wounds. In West Virginia, estimates of economic losses caused by Tabanidae have not been attempted.

Published references to West Virginia Tabanidae are few. Early "Virginia" records may in fact be from West Virginia, which was part of Virginia until 1863 (Clark and Clark, 1951). Many published records of West Virginia tabanids give only the location "W. Va.," omitting county and date citings. Brennan (1935) was the first to report Goniops chrysocoma and Chrysops moechus from the state. Stone (1938) mentioned Hybomitra miniscula from "W. Va.," but the source of this record was not given. Philip (1947) summarized records of Brennan and Stone but added Tabanus molestus, T. similis, and T. sulcifrons. No further information appeared until 1966 when Philip reported Chrysops carbonarius as a new state record. The following year, two specimens from West Virginia were designated by Pechuman and Teskey (1967) as paratypes of the newly described Chrysops calvus. Fairchild (1975) described Silvius gigantulus weemsi from specimens collected by Weems at Cranberry Glades. This subspecies is the only tabanid described from the state. Pechuman (1973), in his studies of Virginia tabanids, mentioned the occurrence of Stonemyia tranquilla, Chrysops lateralis, Hybomitra miniscula, $H$. typhus, and Tabanus marginalis in "the neighboring state" of West Virginia. 
Recent additions to our information of the tabanid fauna of West Virginia have been made by Allen and Pechuman (1977) and Hacker et al. (1979).

Many species were suggested as occurring in this state by the catalog of Philip (1947), especially those species for which he cited records from all of the surrounding states. The current study makes reference to published accounts of species occurring in other states (Pechuman, 1972, 1973; Allen and Pechuman, 1975, 1976, 1977; Frost and Pechuman, 1958; Thompson, 1967a, b, 1969, 1971; Hine, 1903; Townsend, 1955; Brimley and Sherman, 1904; Brennan, 1935; Stone, 1938; Philip, 1947, 1965; Brimley, 1922; Ezell et al., 1974; Burnett et al., 1978; MacCreary, 1940, 1963; Daecke, 1907 and Jones and Anthony, 1964, plus unpublished records of Pechuman) to enable one to speculate more accurately as to the probable existence of additional species not yet reported from West Virginia.

\section{METHODS AND MATERIALS}

The objective of this study has been to formulate a concise and accurate picture of Tabanidae in West Virginia. The literature search and review of West Virginia specimens existing in various private and museum collections by Pechuman (unpublished records) has produced information of historical interest, and has aided in defining seasonal and geographic distribution of tabanid species. However, extensive collecting throughout the past four years has added much to our knowledge of the tabanid fauna of the state.

Statewide tabanid surveys have generally utilized several collecting methods which "enable well-defined temporal distributions of dominant species and indicates the presence of occasional and rare forms" (Thompson, 1967a). Collection methods have been reviewed by Frost and Pechuman (1958), Jones and Anthony (1964), Thorsteinson et al. (1965, 1966), and Thompson (1969). Several methods were employed in the current study in order to remove as much collecting bias as possible. Thus, sweep nets, canopy traps, malaise traps, blacklight traps, and larval collecting sieves were utilized. Specimens were also collected from inside automobiles and other enclosed areas such as barns, greenhouses, and porches.

Collection of adults with aerial nets at specific sites of tabanid activity, including sunny spots, puddles in roads, swampy areas with vegetation, flowers, tree sap, aphid exudates, and warm-blooded animals, has historically been the most basic survey method. This method was discussed by Philip (1931) and McAtee and Walton (1918) as it has been important in comparing state survey methods and in capturing specimens for species verification following biological and behavioral observations. Aerial nets were used extensively throughout this study as they are by far the most productive tool for capturing Chrysops specimens, males, and members of the genera Goniops and Stonemyia, which are not attracted to warm-blooded animals.
Blood-feeding females of the rapidly flying giner, Tabanus, Hybomitra, and Atylotus, are best captured in modified canopy or malaise traps. The canopy o Manitoba trap was used in studies by Hanec and Bracke (1964), Matthysse et al. (1974), and Thompson (1962) Modifications resulting from finds by Wilson el d (1966), Thornsteinson et al. (1965, 1966), and Snodty (1970) were incorporated into the canopy trap on Thompson (1969) and Adkins et al. (1972). The ame modifications, including the use of dry ice for the generation of $\mathrm{CO}_{2}$ and a beach ball painted shiny blat. may also be incorporated into malaise traps such as thor used by Roberts (1970a, b), Pechuman and Burtom (1969), or Fairchild (pers. com.). Thompson (1969) observed that Manitoba or canopy traps were ma effective in open areas near water, and within hardnow or hardwood-conifer swamps, less effective in open areas near pastures and old fields, and least effective withina dense forest canopy.

Malaise traps constructed and employed during the course of this study were of the type pictured in Pechuman (1972) and were more easily and cheaply constructed than those of Townes (1962). The nets wete made from green nylon army surplus tent mosquito netting. Two pieces, each $4 \times 15 \mathrm{ft}$., were sewn togetherio form a single net $8 \times 15 \mathrm{ft}$. Along the top edge, another is. $\mathrm{ft}$. long piece of netting was sewn forming a canopy with? $\mathrm{ft}$. wide sides. In a similar operation, vertical baffles wer added at each end of the trap. Grommets were placed at the corners of the net and at the junctions of the baffles and canopy, enabling the trap to be suspended between two $9 \mathrm{ft} . \times 1$ in. $\times 1 \frac{1}{2}$ in. oak poles (Fig. 1). When not in use, the nets were rolled around the poles for easy transport on an automobile roof rack. During this study. the malaise traps were frequently modified by the addition of a black enameled beach ball and dry ice suspended from the canopy in a nylon mesh bag. These traps have proven to be highly successful in most areas, including densely wooded areas characteristic of much of West Virginia. Part of this effectiveness is explained by Roberts (1974), who studied flight heights of several Tabanidae. He observed that few tabanids fly higher than $8 \mathrm{ft}$. from the ground. Pechuman (1972) also mentioned that unlike canopy traps, the malaise trap collects make specimens, an observation verified during this study.

Blacklight traps $\left(\right.$ Elisco $\left.^{\circledR}\right)$ (BLT) were operated at several locations around the state. Two light traps located at the West Virginia University Horticulture and Plant Sciences farm in Morgantown were operated continually from March to November each year throughout this study.

MacCreary (1940) and Philip (1928) mentioned the collection of larvae as an important part of surveys. They found that larvae commonly collected in the field are often species not commonly caught as adults (e.g. Tabanus reinwardtii). Collecting methods for larvae were reviewed by Philip (1928). Sieves of several sizes and mesh 
sizes were tested with minimal success during this study. The best method for extracting larvae from most substances was the utilization of a tool such as a garden ake, a trowel, or a hand ax in sorting through the substrate in situ. Since tabanid larvae are, in general, much more time consuming to collect than are adults, only minimal effort was made with larval sampling during this study.

\section{RESULTS AND DISCUSSION}

\section{Classification}

Records of West Virginia Tabanidae to date represent 18 species and sub-species from the 9 genera listed below. Numbers in parentheses represent the total number of pecies which may actually occur within the state.

\begin{tabular}{lrr} 
Stonemyia & 1 & $(3)$ \\
Goniops & 1 & $(1)$ \\
Merycomyia & 0 & $(1)$ \\
Silvius & 1 & $(2)$ \\
Chrysops & 24 & $(45)$ \\
Neochrysops & 0 & $(1)$ \\
Diachlorus & 0 & $(1)$ \\
Microtabanus & 0 & $(1)$ \\
Chlorotabanus & 0 & $(1)$ \\
Leucotabanus & 1 & $(1)$ \\
Haematopota & 1 & $(1)$ \\
Atylotus & 3 & $(4)$ \\
Hamatabanus & 0 & $(1)$ \\
Hybomitra & 8 & $(13)$ \\
Tabanus & 28 & $(44)$ \\
\multicolumn{1}{c}{ Totals } & 68 & 120
\end{tabular}

\section{Index of Abundance}

In order for the tabanid species of West Virginia to be rated in sequence from the most abundant to least abundant, a mathematical formula was developed to consider factors important in evaluating one species relative to another. Frost and Pechuman (1958) attempted such a rating of the more abundant species in Pennsylvania by simply listing in decreasing order the number of specimens collected during their survey, along with a listing of the number of county records. However, the number of county records obtained for each species did not follow the same decreasing order as did the number of specimens collected. Tashiro and Schwardt (1953b) also gave a listing of the relative abundance in decreasing order of New York Tabanidae using the values of percentage of species represented in the total population swept from one side of an animal for "short but definite periods of time." Obviously, any system of rating tabanids will be biased by the units of measurement employed.

West Virginia has 55 counties. Core (1966) divided the state into six geographical zones, roughly approximating four topographical regions (Fig. 2). The Index of Abundance was computed for species collected in West Virginia during the 1975 and 1976 collecting seasons using three variables: (1) the number of specimens obtained through all collection methods during this study, (2) the number of county records, and (3) the number of geographical zones represented by each species. The values obtained do not reflect fluctuation of seasonal population levels characteristic of most species.

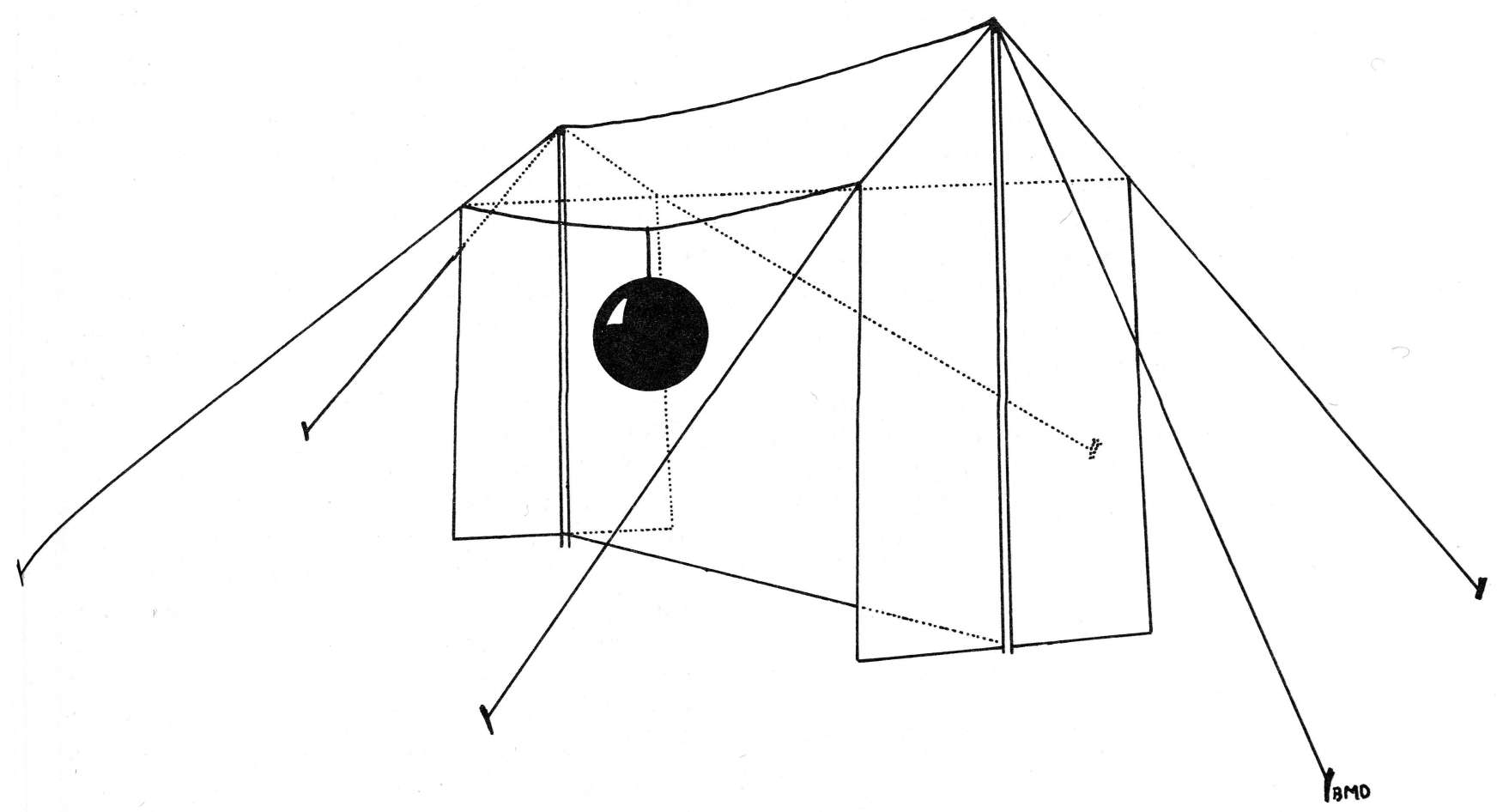

Figure 1. Modified malaise trap employing shiny black enamelled sphere. 


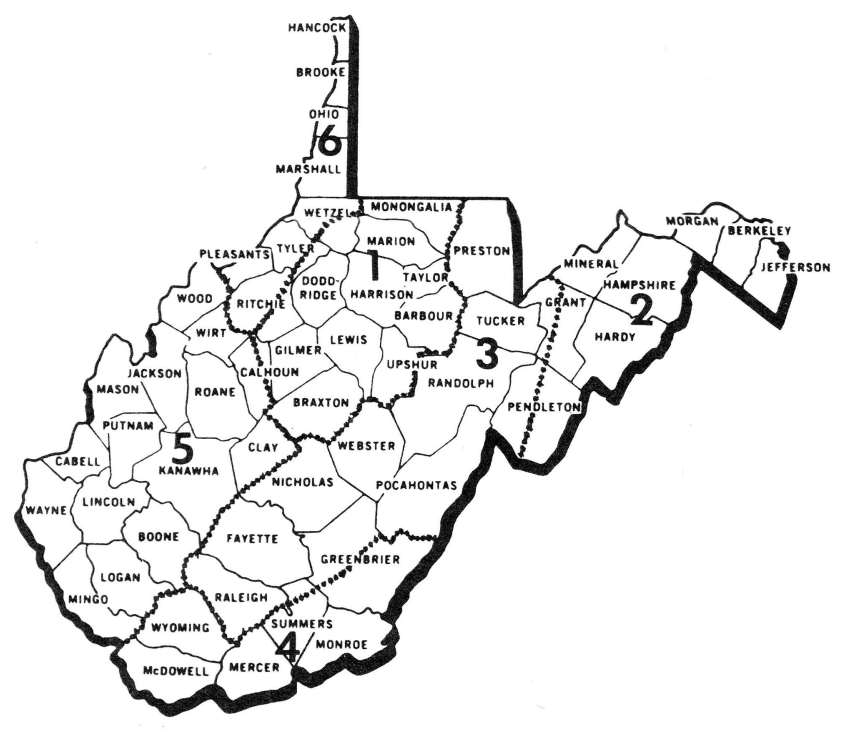

I-North Central

4-Southern

2-Northeastern

5-Southwestern

3-Central

6-Northwestern

Figure 2. Map of West Virginia showing the placement of the 55 counties and the division of the state into six geographical regions (Core, 1966).

The collecting methods have imposed a generic bias since, in contrast to Chrysops, very few Tabanus and Hybomitra were collected in aerial nets. Therefore, it was deemed unadvisable to relate index values for Chrysops to those of Tabanus and Hybomitra; thus, two separate figures are presented to indicate abundance of these genera (Figs. 3, 4).

The variables were converted to percentages of their highest possible values. For example, there are six geographic zones given for West Virginia (Core, 1966) and thus, a species may attain a value of 16.6, 33.3, 50.0, $66.6,83.3$, or 100 percent if they are known from $1,2,3,4$, 5 , or 6 geographical zones, respectively. No species was recorded from more than 18 of 55 counties, and not more than 225 specimens of one species were collected during the 1975 and 1976 seasons of this survey. Thus, 18 and 225 are the maximum values and were used to calculate percent values for the last two variables. The resulting values are averaged together to obtain the Index of Abundance value for each species.

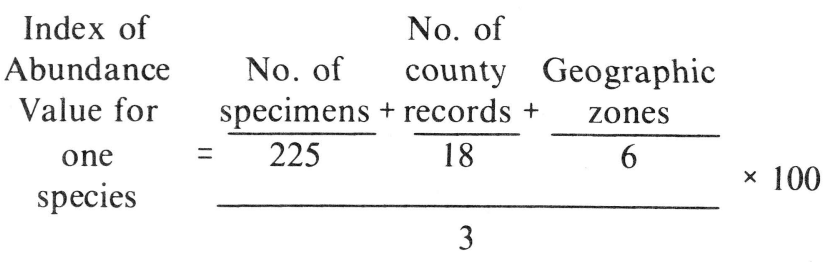

Inherent to this method is the effect of each variable on the Index value. Since this is a statewide survey, it is more important for a species to have records from sevent geographical zones than to have been collected in severt counties in a single zone. Since collecting records resulti three values which are all measures of distribution in ama the value for the number of specimens comprises less the one-third of the calculated Index value. The resultin Index of Abundance values have been plotted i decreasing order for Chrysops species in Figure 3 and fur Tabanus and Hybomitra species in Figure 4. Values of the three variables used to calculate the Index values are alwo shown.

The Index of Abundance values clearly show the mor widely distributed and commonly collected Tabanidae in West Virginia. The six Chrysops receiving the higher Index values are $C$. vittatus, $C$. callidus, $C$. niger, $C$ unvittatus, $C$. macquarti, and $C$. geminatus. The five most highly rated Hybomitra and Tabanus are T. quinquevittatus, $H$. lasiophthalma, $H$. difficilis, ${ }^{\top}$. sackeni and T. sulcifrons. This list of tabanids contain most of the same species listed by Frost and Pechuman (1958) except for the substitution of $C$. geminatus and $C$. univittatus in West Virginia for C. shermani and C. indwe in Pennsylvania. Both the latter species are primarily northern in distribution and are common only at higher elevations in West Virginia.

The term "abundance" now applies to numbers of specimens, county records, and geographic zone records. Methods of estimating species abundance using only numbers of specimens collected sometimes reflect the results from only a few successful collection locations. For example, Hybomitra miniscula was taken only twice during the 1975-76 seasons; all specimens were collected in and around sphagnum bogs. In one day a series of 56 specimens was captured at one location. The large numbers of specimens may have been due to several factors but they cannot be attributed to the distribution of this species at that time. Another species, Hybomirn pechumani, has never been found in large numbers; only 18 specimens were collected during the study period. However, it was collected from five counties representing three of the geographic zones. Obviously, this species is much more widespread and common in areas not associated with sphagnum bogs and thus is probably more abundant in the state. Most important, the Index of Abundance values are meaningful only because they are relative to values calculated for other species.

The Index of Abundance ratings cannot be considered as a true measure of economic importance. With regard to livestock blood loss, several large tabanids (e.g., Tahanus sulcifrons) can draw much more blood and leave larger wounds than can a larger population of smaller (e.g. Chrysops) species. Thus, larger tabanids may be more important in smaller numbers than some of the more numerous but smaller species. Also, the behavioral response of livestock to the sound of attacking larger tabanids may be much more detrimental than that of many smaller species. Although most tabanids are 
$1-100=$ Index of Abundance

$1-225=$ Total Specimens $/$ Species

vittatus

macquarti

cal1idus

niger

univittatus

geminatus

indus

cincticornis

calvus

cuclux

shermani

moechus

carbonarius

lateralis

sequax tau

pikei

ater

sackeni

flavidus

montanus

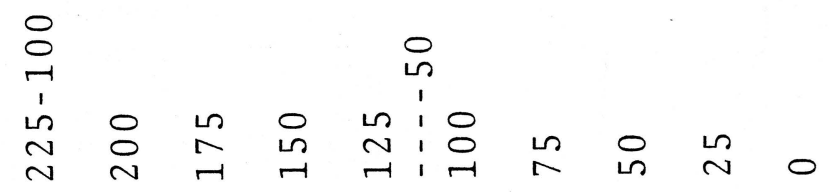

$\begin{array}{llllllllllllllllll}1 & 1 & 1 & 1 & 1 & 1 & 1 & 1 & 1 & 1 & 1 & 1 & 1 & 1 & 1 & 1 & 1 & 1\end{array}$

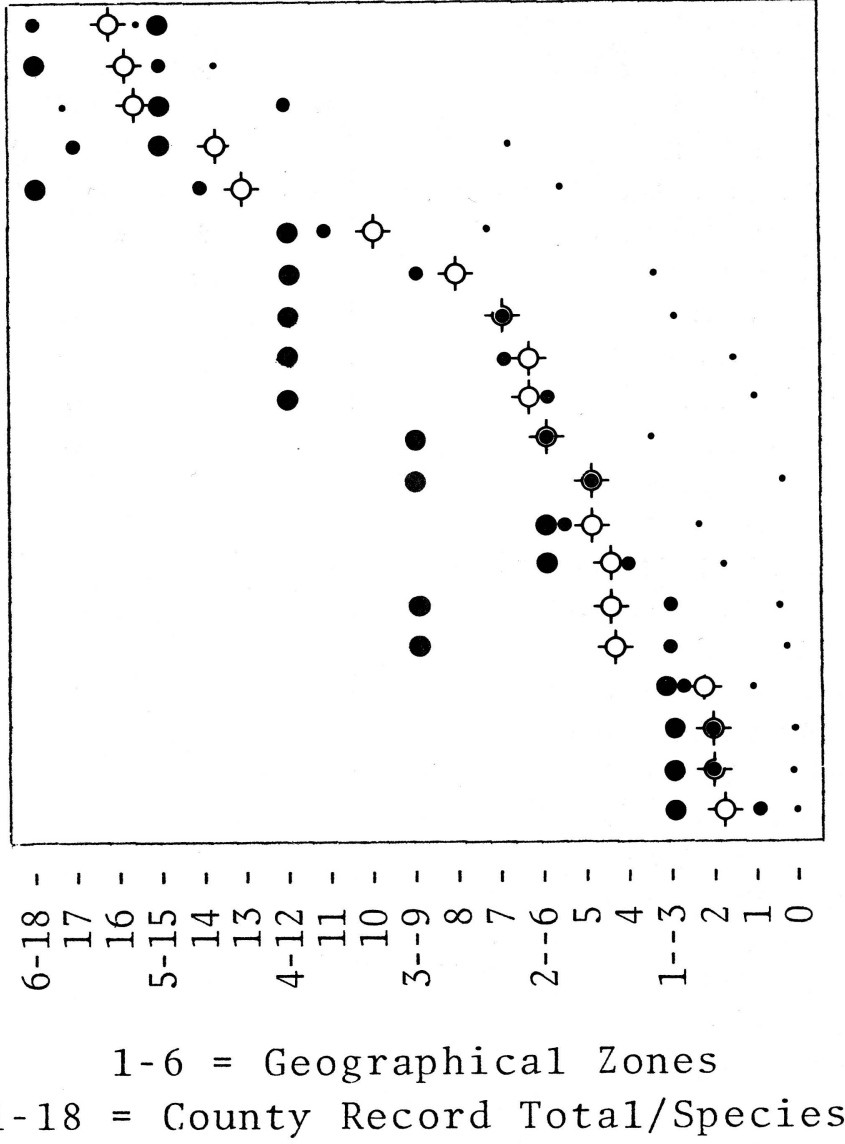

Index to Figures $3 \& 4$

- = Total number of specimens examined

- = Total county records

- = Total geographical zone records

$\phi-\phi$ Index of abundance

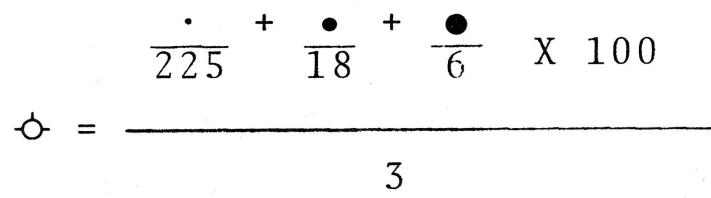

Figure 3. Index of abundance rating for 20 species of West Virginia Chrysops as determined from number of specimens, number of county records, and number of geographical zone records. 
T. quinquivittatus

H. lasiophtha1ma

H. difficilis

T. sackeni

T. sulcifrons

T. sparus milleri

T. subsimilis

T. 1ineola

T. pumilus

T. fulvulus

H. sodalis

T. similis

T. nigripes

H. pechumani

T. superjumentarius

T. trimaculatus

T. calens

H. microcephala

T. pallidescens

T. americanus

T. fairchildi

H. miniscula

T. nigrescens

T. vivax

T. 1ongus

T. atratus

T. sublongus

T. marginalis

T. sagax

T. reinwardtii

T. novaescotiae

T. molestus

T. catenatus

H. cincta

H. aurilimba

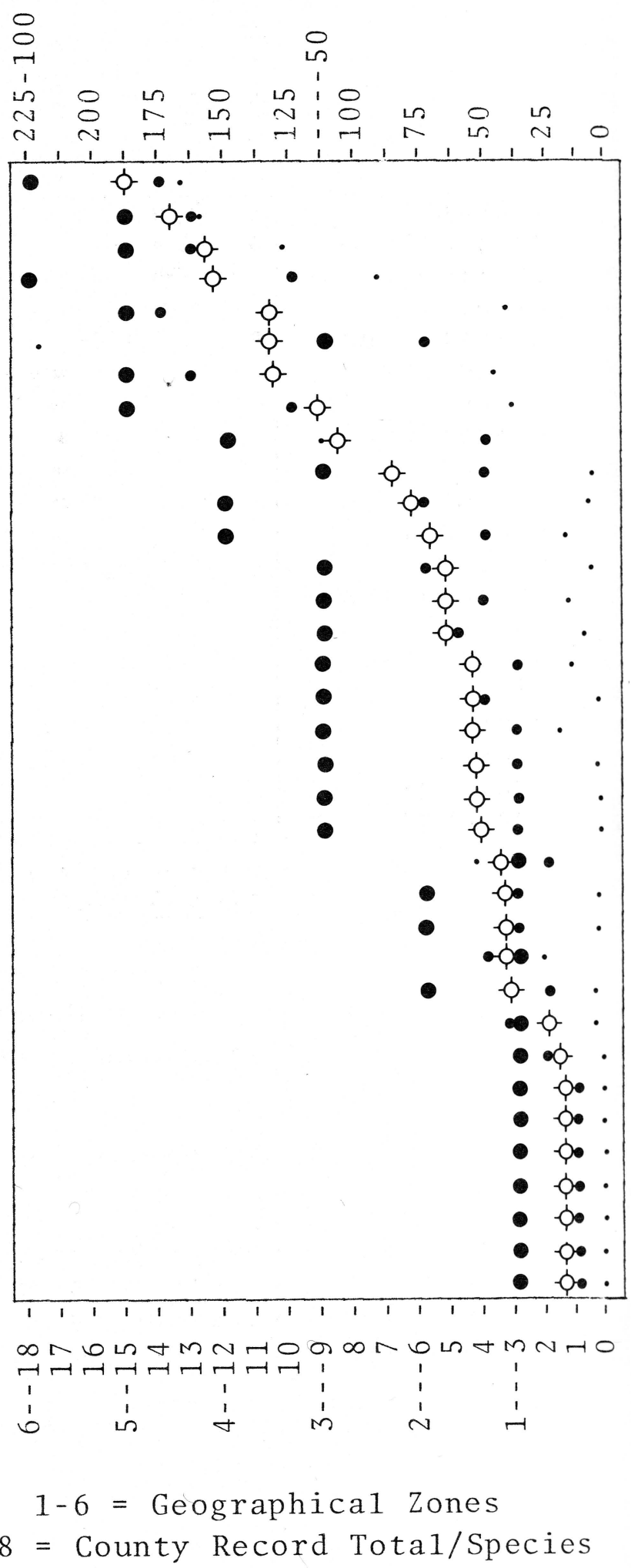

Figure 4. Index of abundance rating for 35 species of West Virginia Tabanus and Hybomitra as determined from number of specimens, number of county records, and number of geographical zone records. 
capable of spreading diseases mechanically, those with larger mouthparts are capable of transmitting greater quantities of pathogens and thus may be more important vectors. However, if one species is known to be the vector of a particular disease (e.g., Chrysops discalis and tularemia or deer-fly fever), it can be very important, even in small numbers.

Finally, the less commonly collected "rare" species, those with low Index of Abundance values, may not be at all rare or limited in distribution. Species response to collecting methods may be greatly biased due to behavioral idiosyncrasies, including habitat and oviposition preferences, host preferences, short flight seasons, and meteorological factors affecting activity. These factors should be considered with regard to the status of West Virginia Tabanidae and their Index of Abundance values.

\section{Taxonomy, Distribution, and Habits}

Keys to species of West Virginia Tabanidae and short taxonomic discussions are given in the following sections. In some cases (Chrysops, Hybomitra, and Tabanus), keys to males as well as females are provided because of frequent dimorphism. Males are quickly distinguished from females by their contiguous eyes. Following the keys and taxonomic discussions are alphabetical listings of the species with distribution records, information on known distributions, and peculiar forms or habits observed during this study.

Specific names of tabanids are followed by the name of the author. The "seasonal range" consists of extreme dates of capture of the species in West Virginia, followed in parenthesis by extreme dates of capture of the species in states near West Virginia. Extreme dates for the surrounding states are not given where West Virginia records exceed them.

"Distributional records" include alphabetically listed county names in capital letters, specific locations, date of capture, initials of collectors, and initials of the collections where the specimens are housed. Where initials of the collector appear twice, the collector is in possession of the specimens.

\section{Names and Initials of Collectors}

J. Amrine ......................... JA

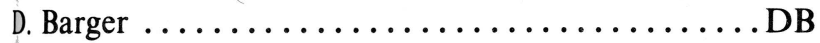

R. Barrat........................ RB

J.W. Begley .................... JWB

E. Bostic ......................... EB

J. C. Bradley .......................

S. W. Bullington $\ldots \ldots \ldots \ldots \ldots \ldots \ldots \ldots$ SB

J. Burger ....................... JB

L. Butler .......................... LB

P. Calise ........................ PC

C. C. Coffman ...................... CC

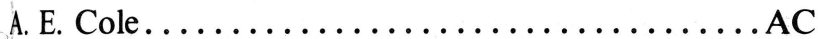

R. DeHaven ...................... RD
B. M. Drees $\ldots \ldots \ldots \ldots \ldots \ldots \ldots \ldots \ldots \ldots$. . . . . . .

R. M. Dunst.................... RMD

E. Estep......................... EE

K. Elrod .........................

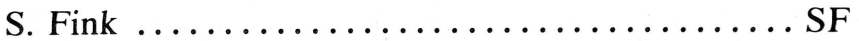

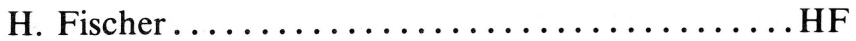

D. Fisher......................

W. Flowers ...................WF

P. Francis .........................

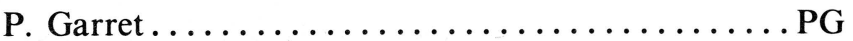

J. D. Hacker .....................JH

J. H. Hall ...................... JHH

D. Harris $\ldots \ldots \ldots \ldots \ldots \ldots \ldots \ldots \ldots \ldots \ldots$ DH

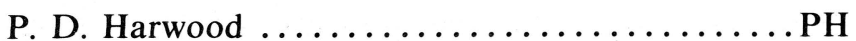

K. Hinkley $\ldots \ldots \ldots \ldots \ldots \ldots \ldots \ldots \ldots \ldots \ldots \ldots \ldots$

R. Johnson ...................... RJ

W. T. Johnson ...................WJ

T. Keeney ......................... TK

K. V. Krombein .................... KK

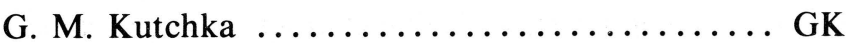

R. Lindsey $\ldots \ldots \ldots \ldots \ldots \ldots \ldots \ldots \ldots \ldots$ RL

G. Lippert ...................... GL

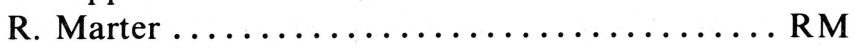

T. L. Mason ...................... TM

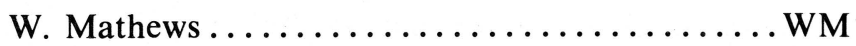

H. Menke ........................

H. M. Milliron.....................MM

J. McCabe .........................

K. McDonald ..................... KM

B. Nierwienski ....................

W. Northeimer ...................WN

H. Palestine.$\ldots \ldots \ldots \ldots \ldots \ldots \ldots \ldots \ldots$ HP

L. M. Peairs .................... LMP

L. L. Pechuman .....................LLP

F. L. Pogge ...................... FP

G. Post $\ldots \ldots \ldots \ldots \ldots \ldots \ldots \ldots \ldots \ldots \ldots$ GP

C. Power.........................

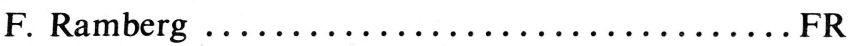

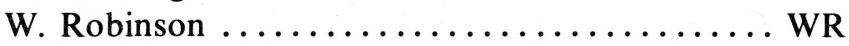

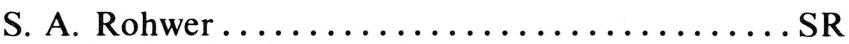

C. W. Sabrosky ...................WS

C. V. Stafford $\ldots \ldots \ldots \ldots \ldots \ldots \ldots \ldots \ldots$ CVS

C. Stuart ......................

P. Swope....................... PS

R. Swope $\ldots \ldots \ldots \ldots \ldots \ldots \ldots \ldots \ldots$ RS

H. Teskey .........................

P. H. Thompson .................. PT

R. J. Thompson.................... RT

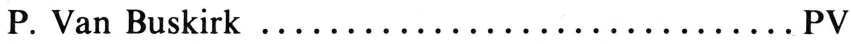

J. Vandevender .....................JV

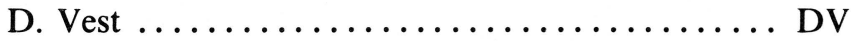

G. E. Wallace ....................... GW

H. V. Weems .....................WW

R. White $\ldots \ldots \ldots \ldots \ldots \ldots \ldots \ldots \ldots \ldots$ RW

J. Wilhelm ....................WW

M. Winters .......................WW

R. Winters $\ldots \ldots \ldots \ldots \ldots \ldots \ldots \ldots \ldots \ldots \mathrm{RW}^{1}$ 
Names and Initials of Collections

Carnegie Museum of Natural History ......... CM

Cornell University .....................CU

Florida State Collection of Arthropods........ FSCA

Harvard University .................... HU

Kansas State University ................ KSU

Michigan State University ................MSU
North Dakota State University ................ ND

Ohio State University .................. OSU

University of Arkansas ................... UA

U.S. National Museum................ USNM

Virginia Polytechnic Institute and State University VPI

West Virginia Department of Agriculture.... WVDA

West Virginia University .................WVU

\section{KEY TO GENERA OF WEST VIRGINIA TABANIDAE}

The family Tabanidae can be separated from other dipterous groups by the presence of three freely articulated antennal segments, pulvilliform empodia with three tarsal pads, conspicuous calypters, and a closed anal cell. The third longitudinal vein is divergent and its upper and lower branches enclose the wing tip; the anal vein is straight or slightly curved (Borror et al., 1976).

There are few distinguishing characters in Tabanidae. Much dependence has been placed on color pattern, making it difficult to determine greasy or partly denuded specimens. Many of the distinguishing characters are confined to the head and its appendages. Figures which appear throughout the keys illustrate the more important taxonomic characters. These figures were redrawn from camera lucida drawings made by the first author from specimens in his possession from WVU and OSU collections and from the collection of L. L. Pechuman and Cornell University. Where specimens were unavailable, the figures were redrawn from the original species descriptions by Fairchild (1975), Hine (1912), Stone (1938), McAtee and Walton (1918), Brennan (1935), and Pechuman and Teskey (1967). Characters which are illustrated in the keys should not be used to the exclusion of other characters in the couplet. Abdominal patterns are figured for many species. These patterns may vary with respect to the proportion of light to dark colors, but the overall designs usually remain constant. The species keys and figures have been integrated into the state records and discussions in order that specific information can be more easily located.

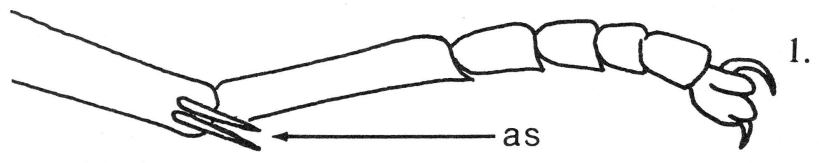

1. a. Hind tibia with 2 apical spurs (as)

b. Hind tibia without apical spurs

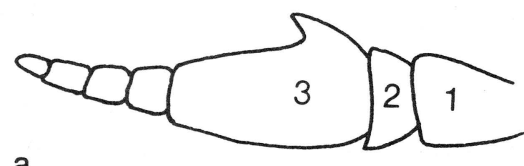

a
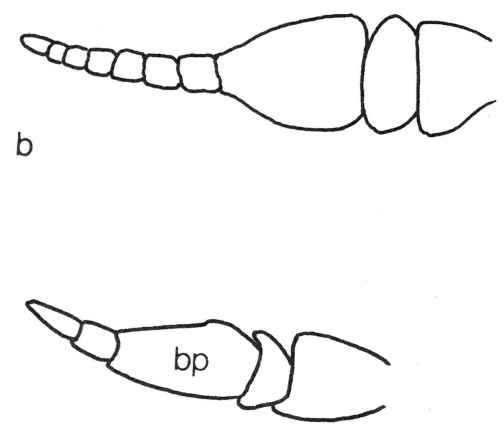

a

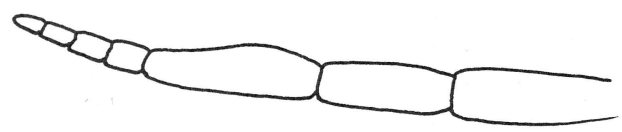

b
2. a. Third antennal segment (3) with five or less distinct annuli $\ldots . .3$

b. Third antennal segment with 8 distinct annuli

3. a. Third antennal segment composed of a rather broad basal plate (bp) and 2 or 3 annuli; first antennal segment only slightly longer than wide and total length of antenna equal to or shorter than thickness of head; larger (over $15 \mathrm{~mm}$ ), Tabanus-like species without definite wing pattern; very small hind tibial spurs .....Merycomyia

b. Third antennal segment composed of five annuli, terminal four annuli distinctly shorter and narrower than the first 


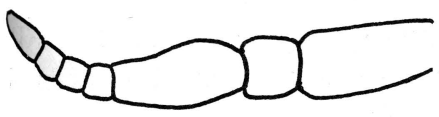

a

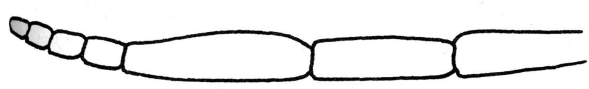

$b$

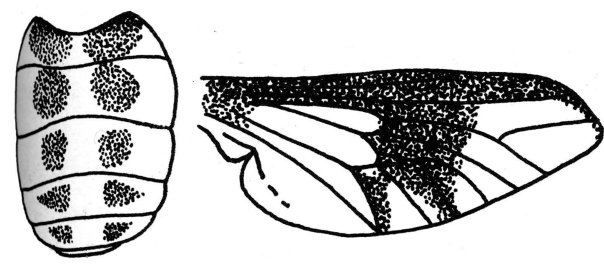

a

b
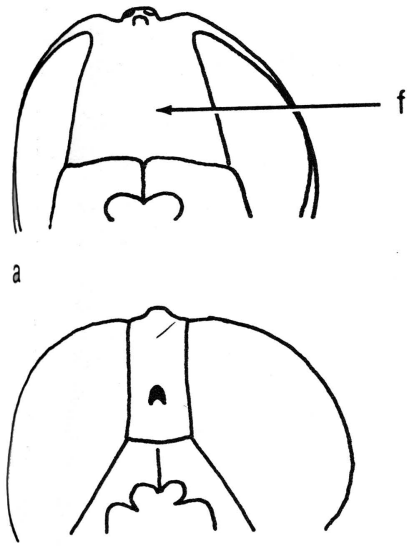

b
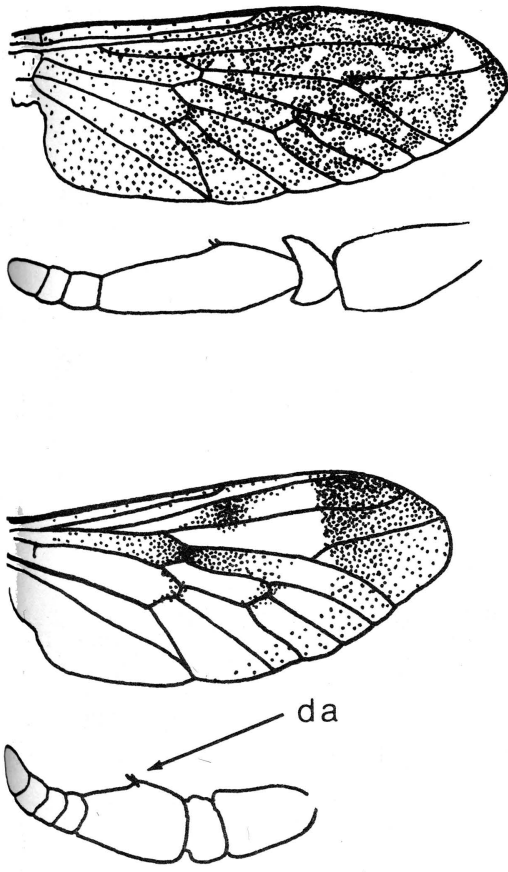

4. a. Second segment of antenna about half as long as first; mostly yellow or yellowish species

Silvius

(page 16)

b. Second segment of antenna more than half as long as first, often nearly as long

$\ldots .5$

5. a. Abdomen globose, wider than thorax, with 2 rows of dark spots; wings rather evenly fumose

..... Neochrysops

(page 37)

b. Abdomen slender and variously marked or unpatterned; wings with definite light brown to black patterns

..... Chrysops

(page 16)

6.(2)a. Eyes of female with upper angles acute; frons (f) broader than width of eye; wings with dark pattern

Goniops

(page 15)

b. Eyes of female normal; frons narrower than width of eye; wings hyaline

Stonemyia

(page 15)

7.(1)a. First antennal segment longer than wide; frons of female widened below, broader than high; wing gray with white maculations

Haematopota

(page 37)

b. First antennal segment usually scarcely longer than wide; frons of female higher than broad; wing pattern, if any, not as above ....8

8. a. Third antennal segment with no dorsal angle (da); frons of female narrow; median callus a narrow line; wings with a dark pattern; eyes bare; no ocellar tubercle; fore tibiae swollen; basicosta (subepaulets) bare

Diachlorus

(page 37)

b. Not with this combination of characters 

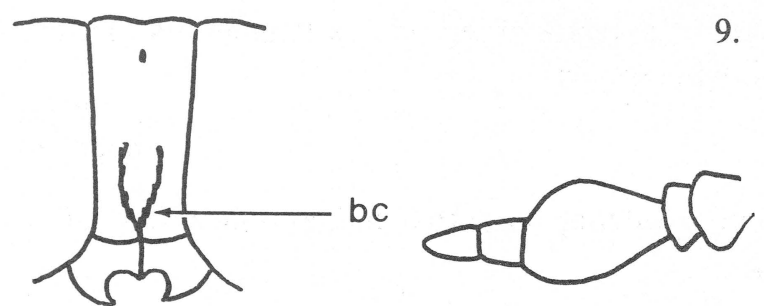

b. Third segment of antenna with 4 distinct annuli; size variable usually more than $10 \mathrm{~mm}$; frontal callus present or absent

.....10

10. a. Small but distinct ocelli (o) present; frons narrow; frontal callus (fc) narrow and ridgelike, well removed from eyes

..... Leucotabanus

(page 37)

b. No ocelli, but an ocellar tubercle may be present; frons, and callosities if present, variable

a. Frontal callosities lacking
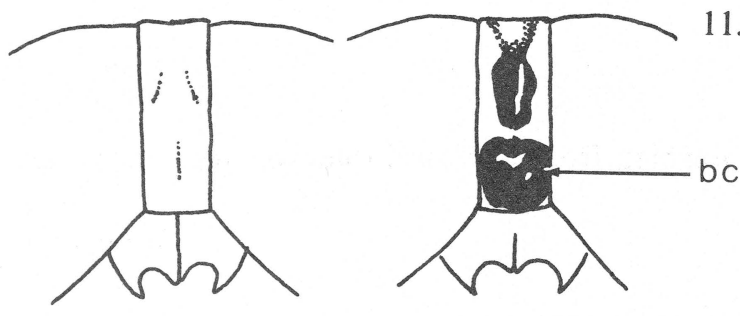

a

b

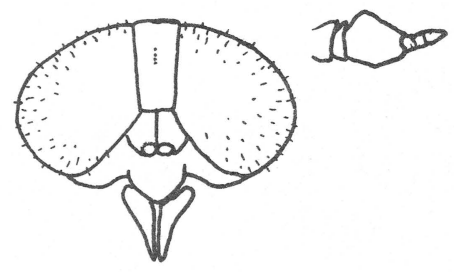

12. a. Eyes hairy; labella fleshy; dark yellowish, gray or brownish species

..... Atylotus

(page 38

b. Eyes bare; labella with sclerotized plates; greenish species in life Chlorotabanus (page 37)
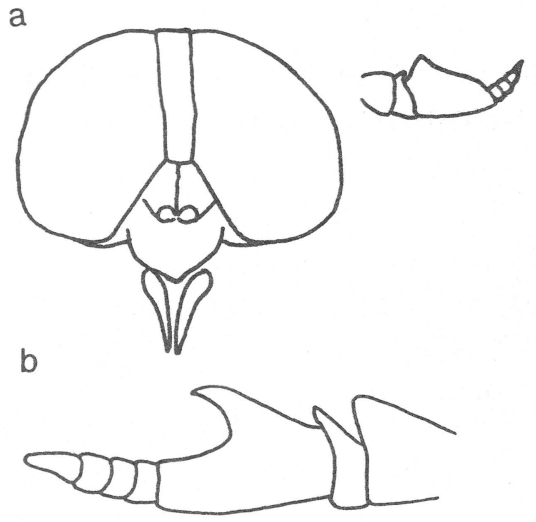

13. a. Third antennal segment with a hooklike projection from basal plate nearly reaching base of annulate portion; eyes sparsely hairy

..... Hamatabanus

(page 39)

a

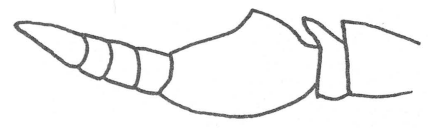

b. Third antennal segment rarely with such a projection but if present, eyes bare 


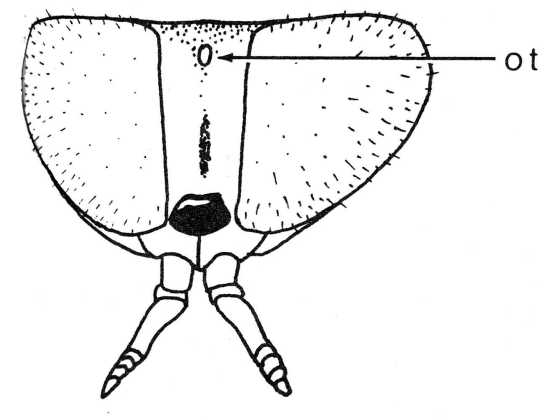

14. a. Vertex with a distinct denuded ocellar tubercle (ot) in female; male with an elevated anteriorly shining tubercle; eyes usually hairy

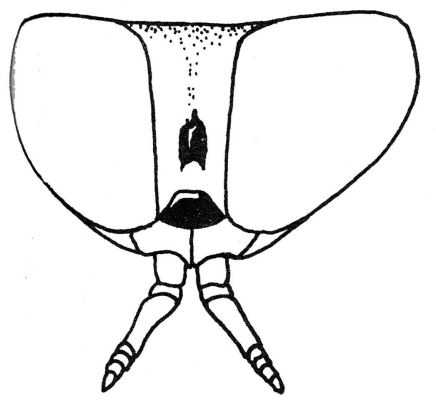

b. Vertex of female without an ocellar tubercle; if an elevated tubercle is present in the male, it is completely pollinose; eyes bare or hairy

\section{Subfamily PANGONIINAE}

Tribe Pangoniini

Genus STONEMYIA Brennan

Species of this genus are not known to suck blood, being found only on flowers or resting on the ground in open areas. The three species which should occur in West Virginia are not common, nor is anything known of their biology. They can be distinguished as follows (Pechuman, 1972):

1. a. Antennae, legs, and body overall yellowish ..... isabella (Wiedemann)

b. Antennae, at least partly dark; legs reddish to black $\ldots .2$

2. a. Legs reddish brown; posterior margins of abdominal segments with grayish hair ....rasa (Loew) hair .....tranquilla (Osten Sacken)

Stonemyia isabella (Wiedemann)

This species is not yet known from West Virginia but has been found in all of the neighboring states between 12 June and 31 July. Stonemyia rasa (Loew)

As a northern species, $S$. rasa should be found in the central highlands of West Virginia. Specimens have been collected in all the surrounding states except Kentucky between 12 June and 7 August.

Stonemyia tranquilla (Osten Sacken)

Seasonal Range-26-VII to 6-VIII (13-VII to 21-VIII).

Distribution-RANDOLPH, Roaring Plains, 26-VII76, LB and BD, WVU.

POCAHONTAS to RANDOLPH, Cheat Mt., 6VIII-60, MM, CM.
This species is northern but ranges south to northern Georgia in the mountains. It is found in mountainous areas of West Virginia.

Drees and Butler found this species abundant on flowers in RANDOLPH. Frost and Pechuman (1958) also reported capturing many specimens from flowers of Spiraea latifolia. More females than males were taken, and a few males were observed as prey of crab spiders (Thomisidae).

Tribe Scionini

Genus GONIOPS

Goniops chrysocoma (Osten Sacken)

Seasonal Range-29-V to 30-VIII (13-V).

Distribution-BERKELEY, Sleepy Creek Publ. Hunt. and Fish. Area, 8-VI-77, HT, HT. 
GREENBRIER, White Sulfur Springs, 11-VIII-12, WR, USNM (Philip, 1941). HARDY, Lost River State Park, 19-VII-74, HM, USNM (as prey of Crabo monticola det. Thompson). MONONGALIA, Coopers Rock State Forest, 30-VIII-75, JA, WVU. PRESTON, Chestnut Ridge, 1974, WM, WVU (larva). PUTNAM, VI-76, DH, WVU. TUCKER, Blackwater Falls State Park, 14-V-76, LB, WVU (larva). WETZEL, Lewis Wetzel Public Hunt. and Fish. Area, 18-VI-76, LB and BD, WVU (larva). WOOD, 7-VII-75, TM, TM.

This species has a general distribution from Ontario south to AR and SC (Philip, 1965), especially in forested areas. Larvae are terrestrial, being found in leaf litter and soil of hardwood forests. The larva collected in TUCKER was found in a decaying beech tree well above soil level. This habitat seems to be unique and unreported.

The specimen from HARDY recorded as prey of Crabo monticola (Hymenoptera:Sphecidae) is the only confirmed predator-prey record of a West Virginia tabanid.

Subfamily CHRYSOPINAE

Tribe Chrysopini

Genus SILVIUS

All nearctic species are western in distribution except Silvius gigantulus weemsi Fairchild. S. quadrivittatus (Say) may also be found in West Virginia in the future and may be distinguished as follows (Brennan, 1935):

a. Wings maculate; species gray; costal cell hyaline; frontal callus about half the width of frons, broadly separated from eyes; branches of the third longitudinal vein with apical spots

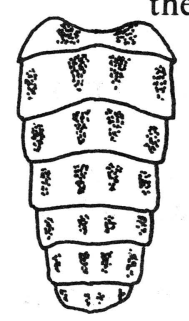
..... quadrivittatus (Say)

b. Wings immaculate; species yellow; frontoclypeus partially denuded; abdominal tergites without median triangles .....gigantulus (Loew)

Silvius gigantulus weemsi (Fairchild)

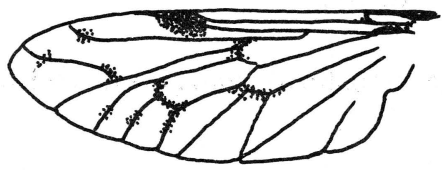

Seasonal Range-12-VIII to (17-VIII).

Distribution-POCAHONTAS, Cranberry Glades, 12-VIII-72, HW, FSCA and colls. of Pechuman and Philip (Fairchild, 1975).
The West Virginia specimens represent an isolate eastern population of $S$. gigantulus (Loew), a specir widespread in western North America. Cranbern Glades is the only known breeding location for this sub-species, although two other specimens (in poor condition) are recorded for PA (ALLEGHENY) and NY. The Weems specimens (8 females) collected in malaise trap at an elevation of $3,400 \mathrm{ft}$. were designated holotype and paratypes (Fairchild, 1975). Males are unknown. Pechuman (pers. com.) believes the Weenr specimens may represent a separate species, as ther have long been isolated from the preglacial continuour population of $S$. gigantulus.

Silvius quadrivittatus (Say)

Although the nearest records of this species are from IL and TN, it appears to be expanding its range eastward and could be found in this state between ? June and 13 August.

\section{Genus CHRYSOPS}

Deer flies are a nuisance to man but probably are less important as pests of livestock than the larger tabanids unless they occur in high numbers. Deer flies persistently attack the top of the head and neck of man. and favor the head, neck, and withers of cattle. Successful attacks are aided by the ability of these flies to approach almost noiselessly, often from downwind. Having landed, they burrow into the hair to bite, much like the smaller Tabanus pumilus and T. sparus milleri.

The deer fly season in West Virginia begins in mid. May ( 9 species encountered) and becomes intense in most areas during June and July (19 and 18 species encountered, respectively). Nine species have been encountered in August but, to date, no Chrysops have been reported during September. Pechuman (1972) has determined the main seasonal occurrence of most species to be rarely over two weeks, although isolated specimens may be found throughout the season. Evidence also indicates a bivoltine cycle for some species. No Chrysops have been found to have a life cycle of more than one year.

The following keys are based primarily upon wing patterns, which, unlike eye coloration, are relatively lon! lasting, although a bleaching effect is noticeable in older specimens.

Because of frequent dimorphism, a separate key is given for males. Male tabanids have contiguous eyes and lack a frons. Both male and female keys are primarily modifications of those of Pechuman (1972, 1973, 1974). 
KEY TO SPECIES OF WEST VIRGINIA CHRYSOPS

\section{FEMALES}

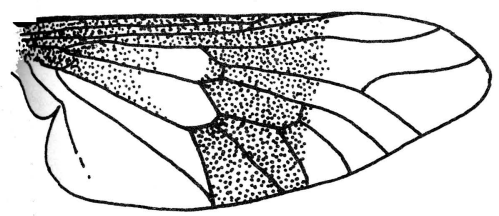

1. a. Apex of wing beyond crossband hyaline

a

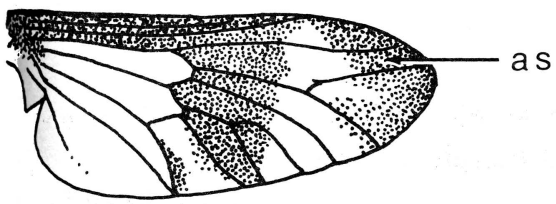

b. Apex of wing infuscated so an apical spot (as) is present

b
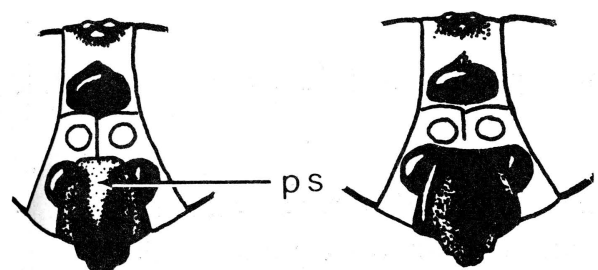

b

a. Frontoclypeus with a pollinose stripe (ps) extending from below antennae one-half or more the distance to the oral margin

b. Frontoclypeus without a pollinose stripe

3. a. Abdomen entirely dark, sometimes with an indefinite pattern of grayish pollinose areas

b. Abdomen with pale areas on at least first 2 abdominal segments .....7

4. a. Fifth posterior cell with hyaline (h) area at base .....5

b. Fifth posterior cell infuscated at base

5. a. Crossband (cb) reaches hind margin of wing rather broadly, outer margin quite straight or slightly bowed; hyaline spot at base of fifth posterior cell large, distinct and clearly defined. Hairs of pleurae gray or yellowish

carbonarius Walker

b. Crossband usually not broadly reaching hind margin of wing, outer margin irregular; hyaline spot at base of fifth posterior cell usually not clearly defined, sometimes almost absent 

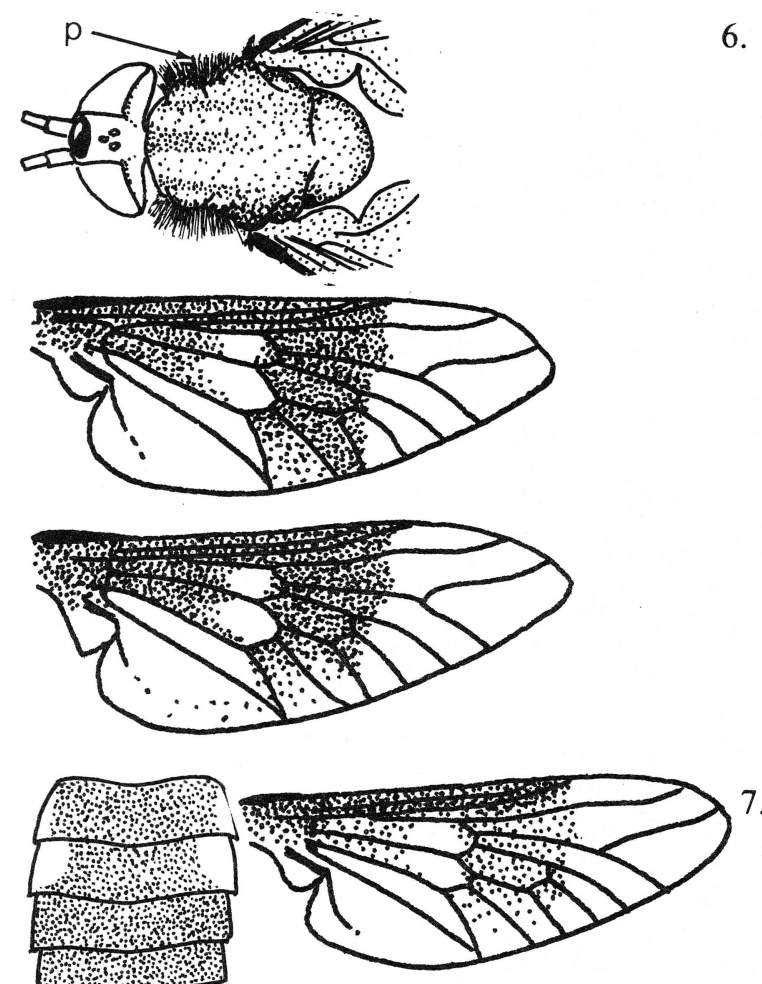

7.(3)a. Wing markings pale; pleura with gray pile; no median abdominal triangles

\section{......cuclux Whitney}

(Occasional specimens of $C$. mitis have small reddish spots laterally at base of abdomen but wing picture is dark.)
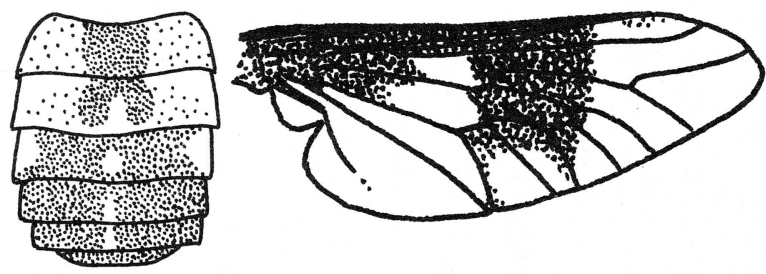

b. Wing markings dark; pleura with yellow or orange pile; median abdominal triangles present

exitans Walker

8.(2)a. Wing pattern pale; crossband does not reach hind margin of wing

b. Wing pattern dark; crossband reaches hind margin of wing

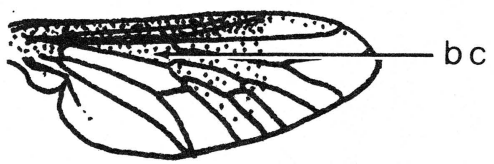

9. a. Abdomen completely dark; first basal cell (bc) dilutely infuscated; crossband dilute, faint pale brown

.....nigribimbo Whitney

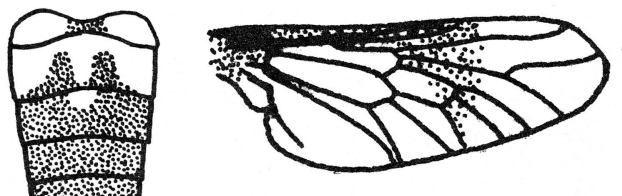

b. Abdomen with a yellow pattern; both basal cells hyaline ..... fulvistigma Hine
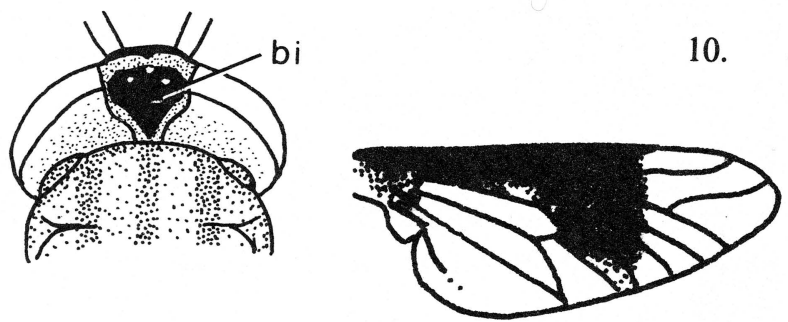

a. Bare integument (bi) runs from ocellar area to occiput uninterrupted by pollinose areas; sublateral thoracic stripes very distinct 

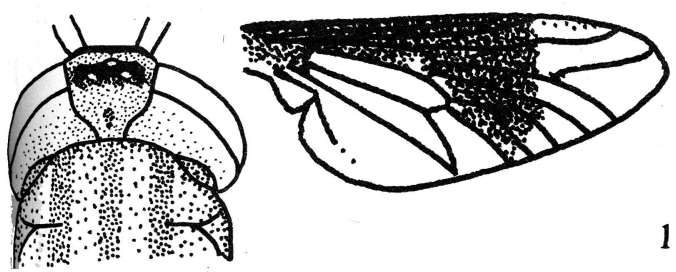

11.(1)a. Frontoclypeus with a pollinose stripe or projection below antennae (see illustration for couplet $2 \mathrm{a}$ )

b. No pollinose stripe or projection on frontoclypeus (see illustration for couplet $2 b$ )

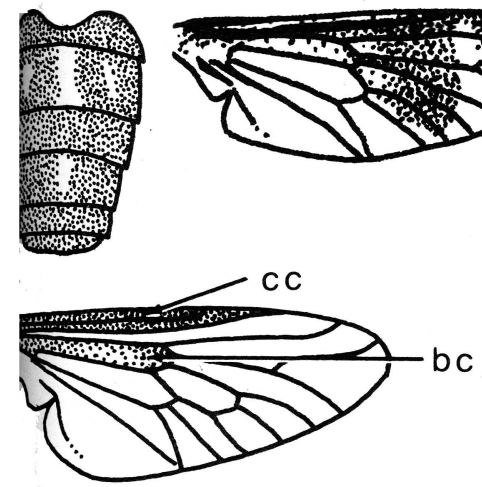

12. a. First basal and costal cells lightly infuscated to nearly hyaline; abdomen black with middorsal yellow stripe and often shorter lateral stripes

.....upsilon Philip

b. First basal cell (bc) and costal cells (cc) heavily infuscated; abdomen yellow with a black pattern

13. a. Hyaline triangle distinctly reaches or crosses second longitudinal vein

.....14

b. Hyaline triangle (ht) does not reach second longitudinal vein (lv2); frontoclypeus usually black with median pollinose stripe; pleura with gray or yellowish pile; abdomen usually not banded but in questionable specimens, black band is not complete; hind tibia reddish yellow to black; legs often with considerable yellow, hind tibia never completely black; apical spot covers entire upper branch of third longitudinal vein

....ffrigidus Osten Sacken
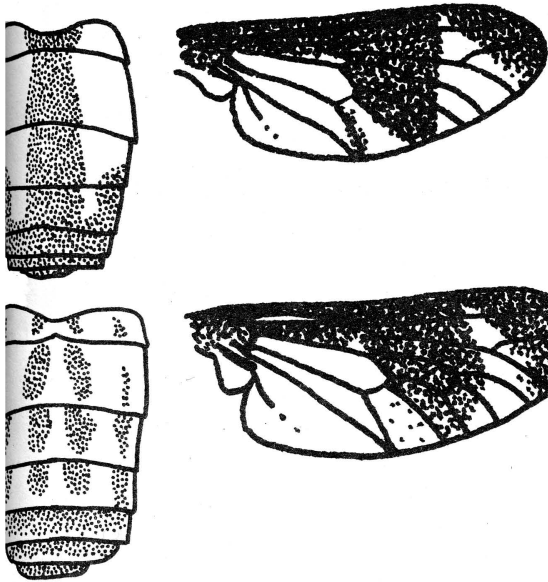

14. a. Frontoclypeus black; abdomen yellow with a single broad middorsal black stripe

dorsovittatus Hine

b. Frontoclypeus yellow; abdomen with four black stripes ..... sequax tau Philip

15.(11)a. Crossband and apical spot broken by dilute areas along veins; abdomen striate

shermani Hine

b. Dark markings of wing not broken by dilute areas 

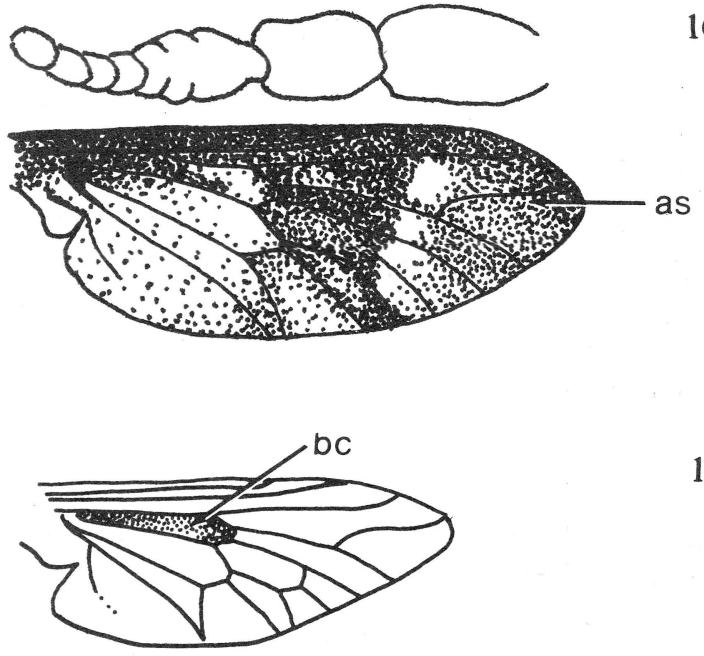

a

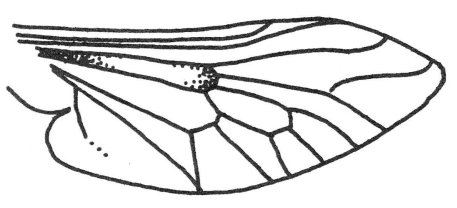

b
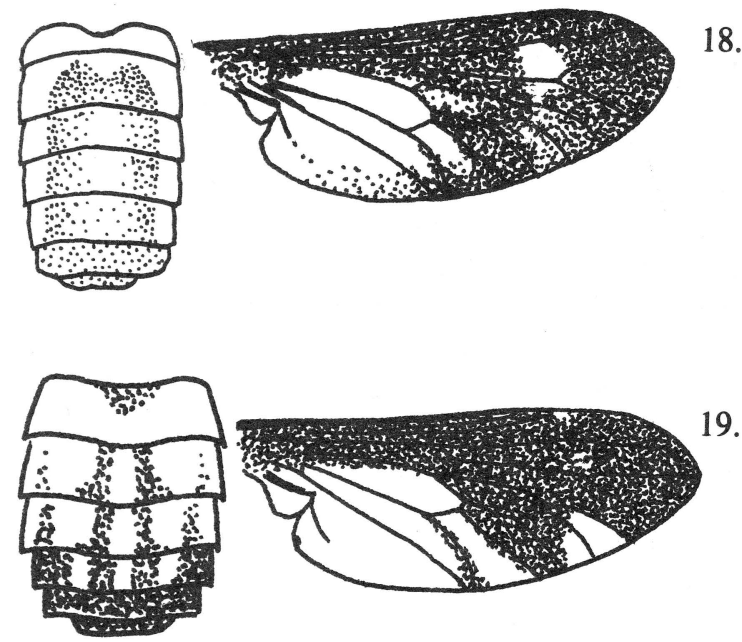

19. a. Hyaline triangle small but clear and distinct, restricted to apicer of second and third posterior cells ..... moechus Osten Sacken

b. Hyaline triangle extending toward costal margin of wing beyond second posterior cell

20. a. Apical spot narrow, entering only upper corner of second submarginal cell; blackish species

b. Apical spot broad, usually covering at least half of second submarginal cell

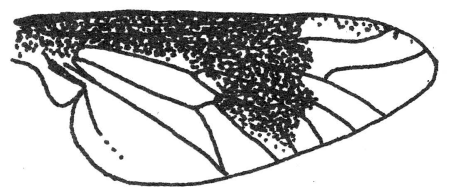

21. a. Bare integument runs from ocellar area to occiput, uninterrupted by pollinose areas; thoracic stripes distinct; apical spot a narrow line; only rarely a small spot at bifurcation (see illustration for couplet 10a) 

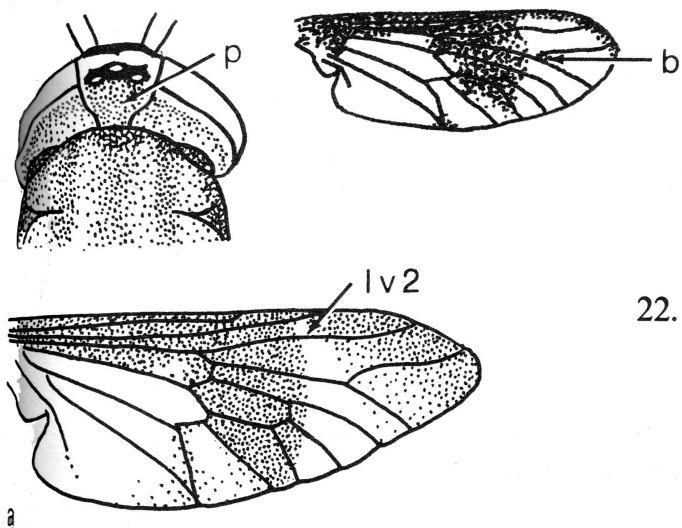

22.
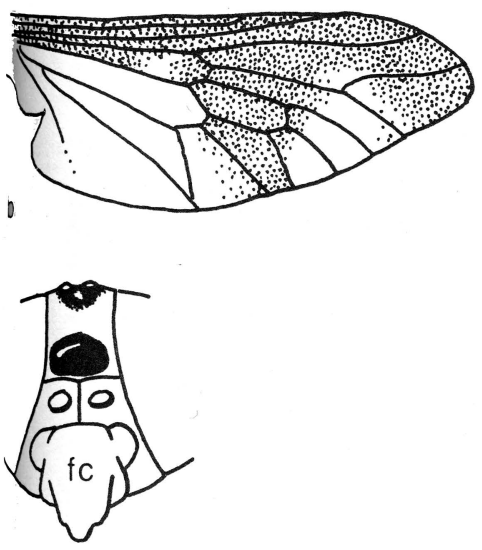

23. a. Frontal callus (fc) yellow

b. Hyaline triangle not extending much beyond the bifurcation and not crescent shaped

b. Frontal callus black or deep brown
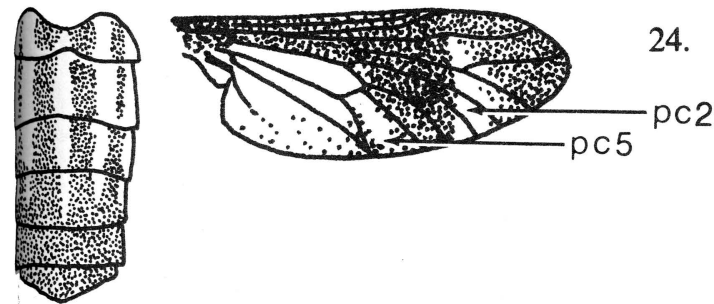

24.
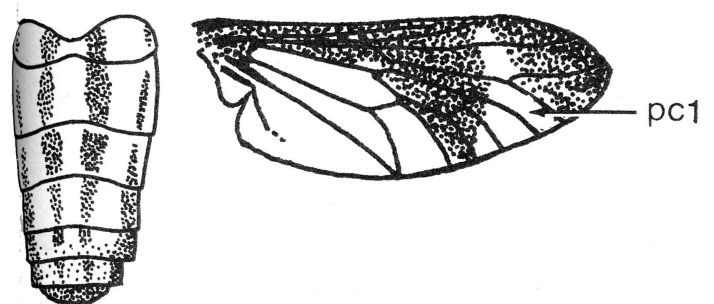

b. Apical spot rarely reaches into first posterior cell (pc1) except as a pale shadow; fifth posterior cell usually entirely hyaline; 4 stripes of abdomen of about equal intensity or central stripes slightly accentuated; thorax between stripes bright yellow

beameri Brennan

25.
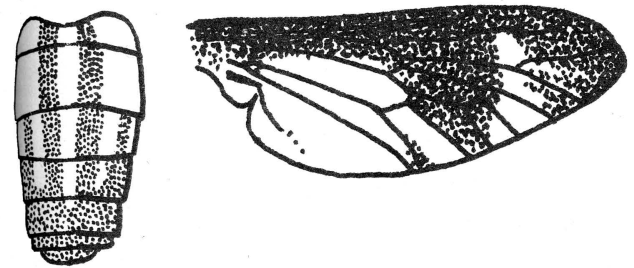

a. Yellowish species with abdomen conspicuously black striped; abdomen with 2 prominent submedian stripes; sublateral stripes absent on tergites $1 \& 2$ and sometimes 3; hyaline triangle rounded at apex

....pikei Whitney

b. Predominantly black or fuscous species with pale abdominal markings, if any, as abbreviated stripes 

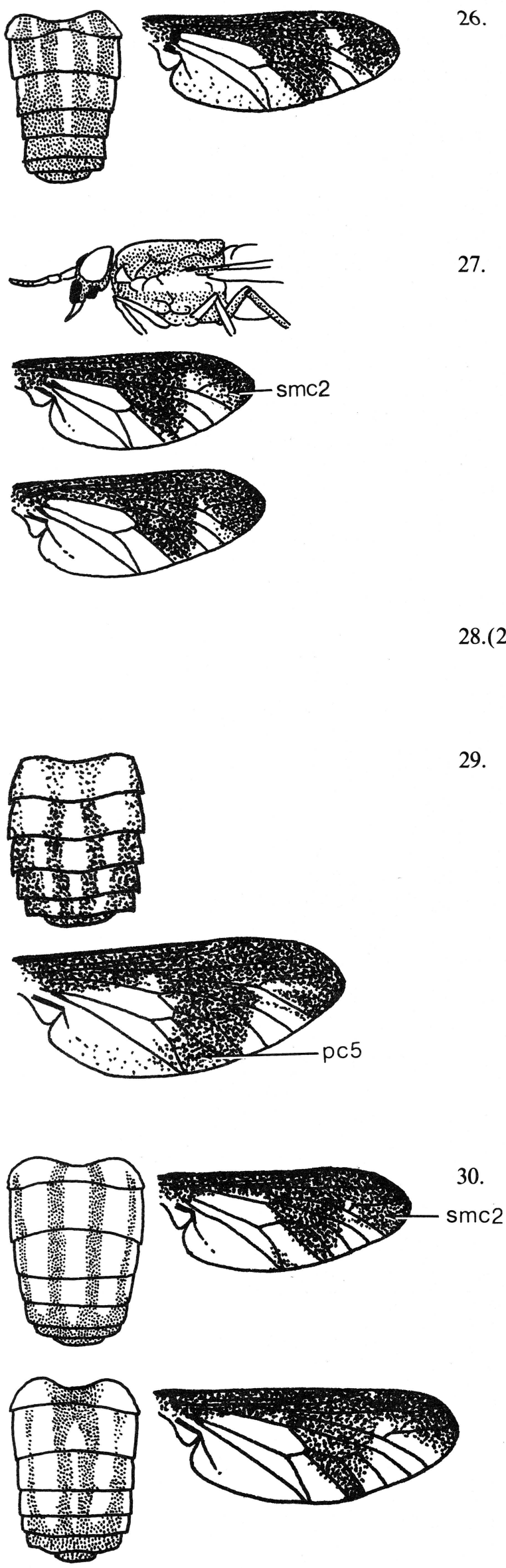

26. a. A yellowish or grayish stripe laterally on thorax above wing base; abdomen usually with three dull yellow stripes which are often much reduced, especially the lateral ones .....obsoletus obsoletus Wiedemann

b. No stripe on thorax above wing base $\ldots .27$

27. a. Hind legs predominantly dark; rarely with any trace of abdominal pattern; apical spot usually not extending beyond second submarginal cell (smc2) .....parvulus Daecke

b. Hind legs predominantly yellow or brownish; abdomen usually with distinct traces of pale median line and occasionally with traces of lateral lines; apical spot usually extends into the first posterior cell

.... dacne Philip

28.(22)a. Abdomen with 4 more or less complete dark longitudinal stripes

b. Abdomen not striped or with less than 4 stripes

29. a. Fifth posterior cell (pc5) almost entirely infuscated; scutellum yellow

vittatus Wiedemann

b. Fifth posterior cell almost entirely hyaline; scutellum dark, with or without paler apex and/or sides

30. a. Apical spot nearly fills second submarginal cell (smc2); 2 central stripes of abdomen rarely joined on second segment; frontal callus usually yellow, sometimes brown or black

..... aberrans Philip

b. Apical spot only about half fills second sub-marginal cell; 2 central abdominal stripes usually join on second segment; frontal callus usually black, sometimes brownish, rarely yellowish 

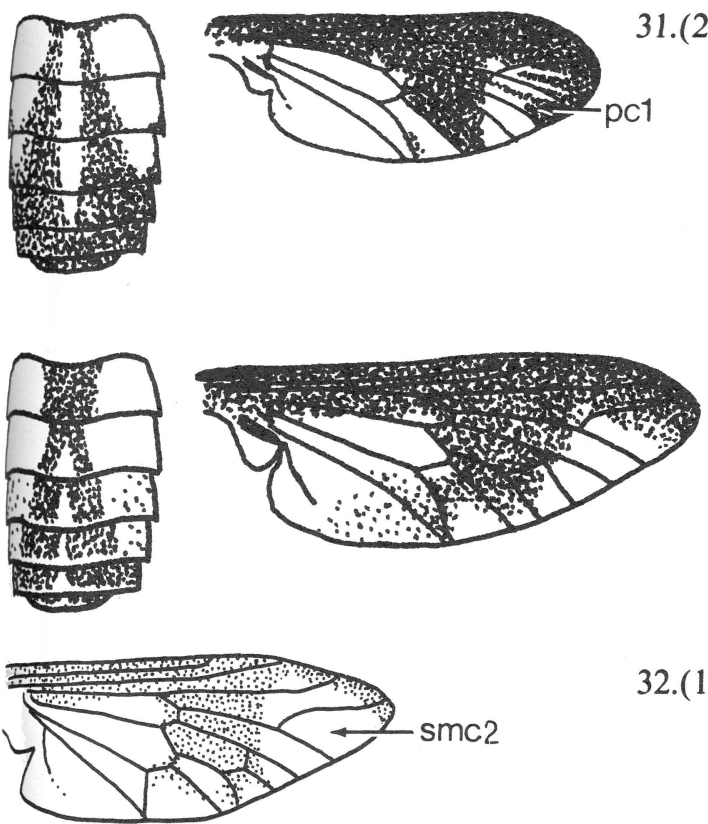

a

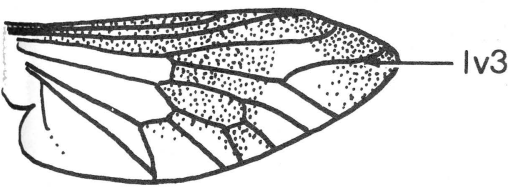

b

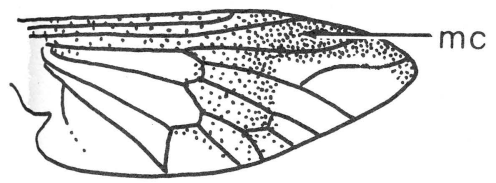

a
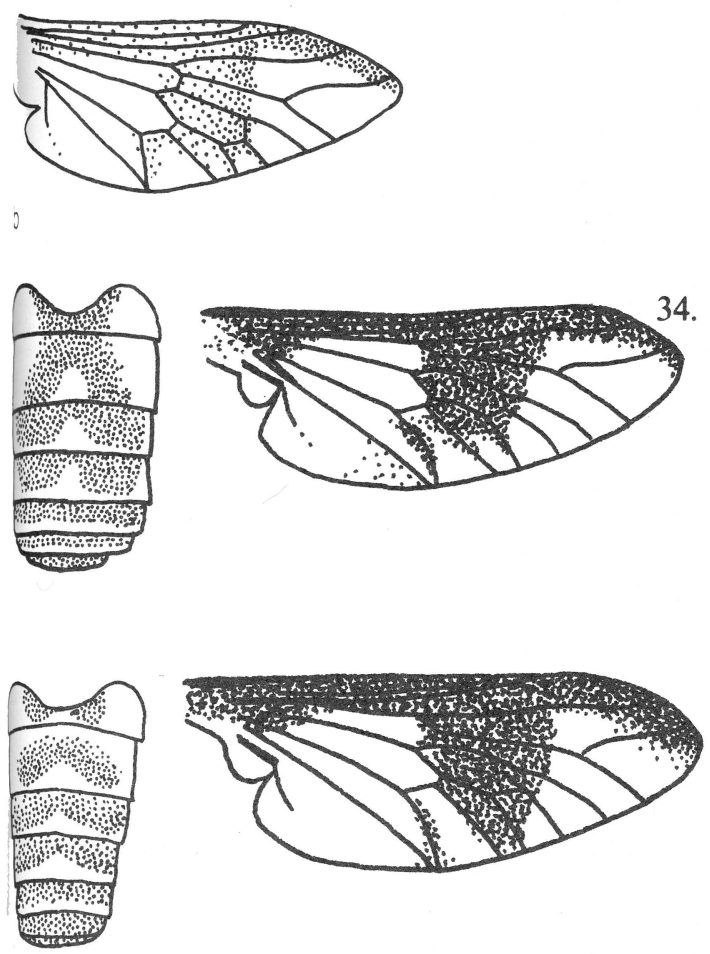

32.(17)a. Apical spot narrow including at most only extreme apex of second submarginal cell (smc2) extends into first and sometimes second posterior cell, usually connecting with crossband by an infuscated streak in first posterior cell (pcl); abdomen with 2 stripes which are sometimes reduced to faint lines or enlarged to cover most of abdomen on each side of a yellow stripe; scutellum usually with considerable yellow

macquarti Philip

b. Apical spot fills only about half of second submarginal cell and does not extend further; abdomen not striped; scutellum dark ..... indus Osten Sacken

b. Apical spot broad, entering second submarginal cell over at least one-third of upper branch of third longitudinal vein (1v3)

33. a. Apical spot beyond where it leaves crossband slightly wider than marginal cell $(\mathrm{mc})$; frontal callus usually yellow, often bordered with black or brown, occasionally black (see illustration for couplet 23)

b. Apical spot at base narrower or just as wide as marginal cell; frontal callus black

a. Black spot on second abdominal segment practically joins with that on first segment; second and third sternites with black sublateral spots; robust species

.....sackeni Hine

b. Black spot on second segment usually does not attain anterior margin of the segment; no sublateral spots on sternites; more slender species 

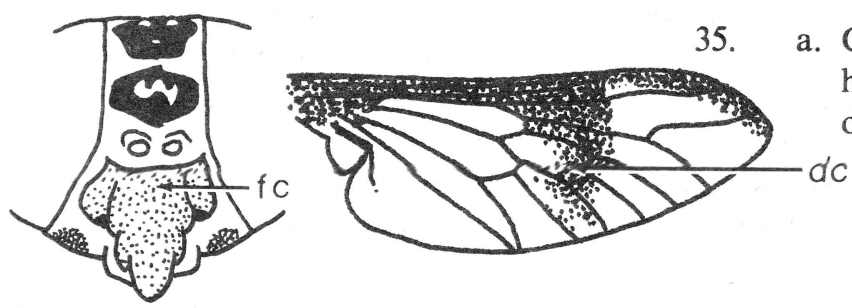

Crossband dilute and leaving about half of the discal cell $(\mathrm{dc})$ hyaline; cheeks black; frontoclypeus (fc) with a large black spot on each side
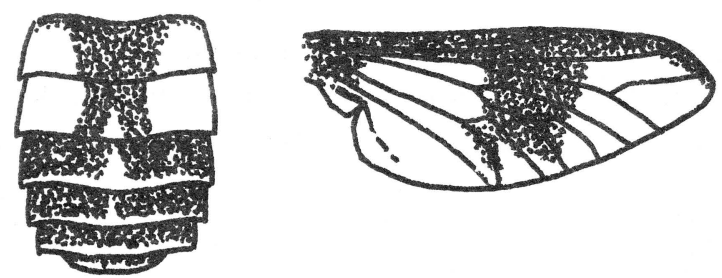

b. Crossband saturate and covering discal cell; frontoclypeus and cheeks yellow or orange

callidus Osten Sacken

36.(32)a. Blackish species with a mid-dorsal yellow (occasionally grayish) abdominal stripe and often with shorter sublateral stripes

b. Abdomen with a different pattern and showing more yellow

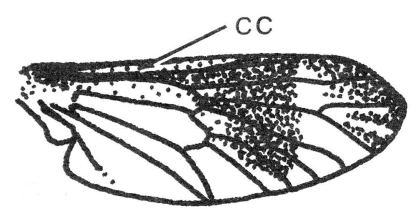

37. a. Infuscation of costal cell (cc) distinctly paler than crossband; apical spot often nearly filling second submarginal cell (smc2) .....upsilon Philip

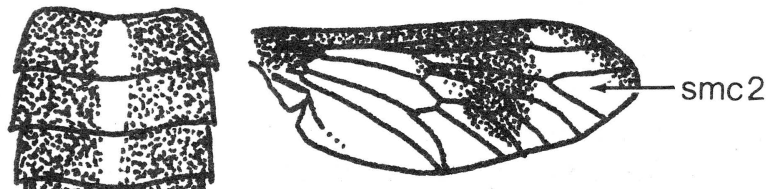

b. Costal cell same color as crossband; apical spot variable but rarely filling as much as half of second submarginal cell

..... univittatus Macquart

38. a. Hyaline triangle distinctly crosses second longitudinal vein (1v2), nearly separating apical spot from crossband

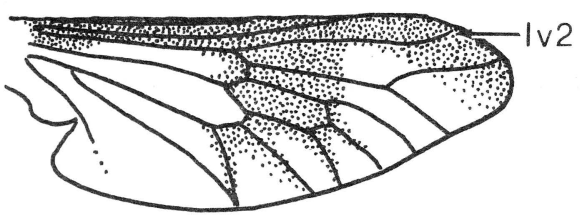

b
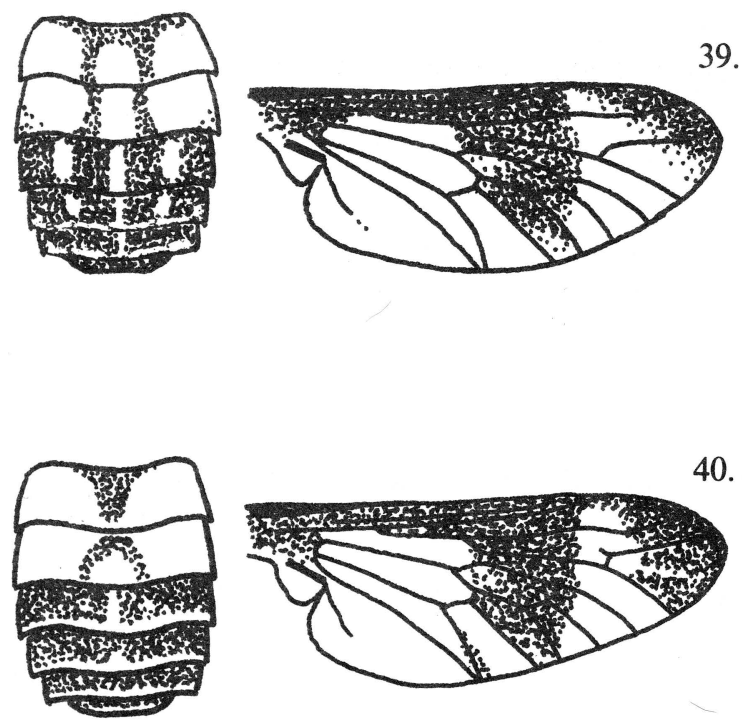

39. a. Apical spot occupies only about half of second submarginal cell; crossband usually does not reach hind margin of wing .....lateralis Wiedemann

b. Apical spot occupies almost all of second submarginal cell; crossband reaches hind margin of wing

40. a. Second abdominal segment with a black inverted "V" or a pair of oblique spots 


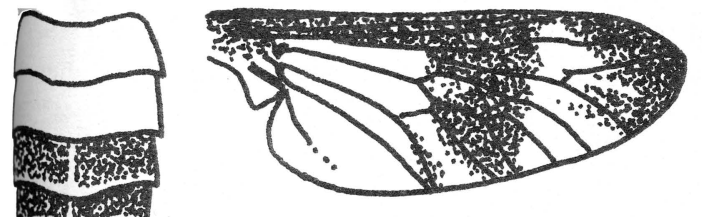

b. Second abdominal segment entirely yellow

.....impunctus Krober

41.(38)a. Abdomen with 4 rows of spots, but lateral spots on second

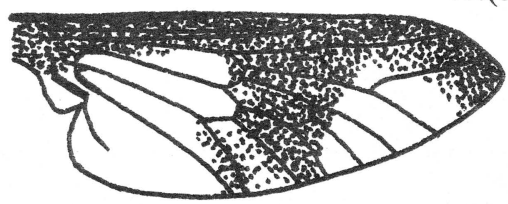
segment may be reduced or absent; median figure on second segment an inverted "V"; scutellum and frontal callus normally dark but the latter sometimes brownish

.....montanus Osten Sacken
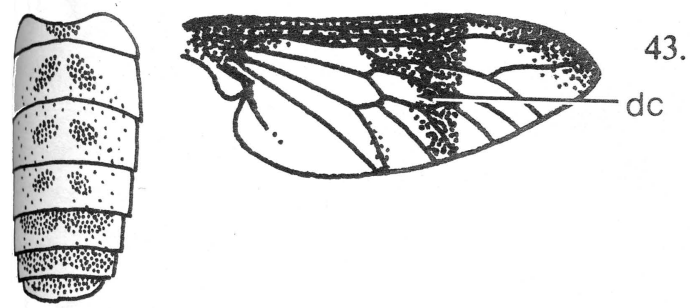

b. Abdomen normally not with 4 rows of spots

42. a. Hyaline triangle reaches second longitudinal vein

b. Hyaline triangle does not reach second longitudinal vein (see illustration for couplet $38 \mathrm{~b}$ )

a. Crossband dilute and basal portion of discal cell (dc) pale or hyaline; frontal callus and hind femora yellow; usually no dark spot under scutellum

cursim Whitney

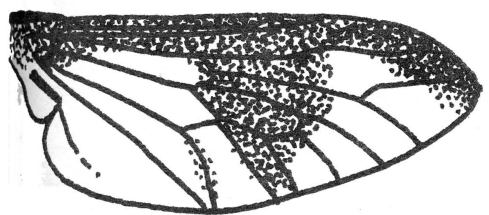

b. Crossband not very dilute and basal portion of discal cell usually concolorous with rest of crossband; frontal callus yellow or fuscous and hind femora usually dark at base; there is a dark spot under scutellum (see illustration for couplet 34b)

.....pudicus (in part) Osten Sacken

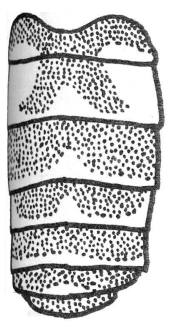

44.

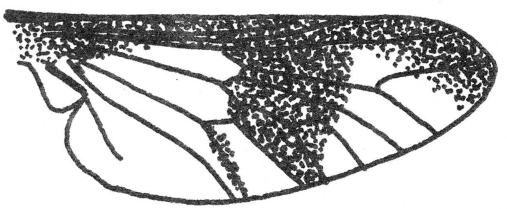

a. Abdominal markings black, median marking of second segment usually reaches anterior margin; frontal callus normally black but sometimes yellow; usually at least basal portion of hind femora black

\section{.....dimmocki Hine}

b. Abdominal markings pale to dark brown, sometimes evanescent; median marking of second abdominal segment rarely attains anterior margin; frontal callus yellow; hind femora yellow to brown

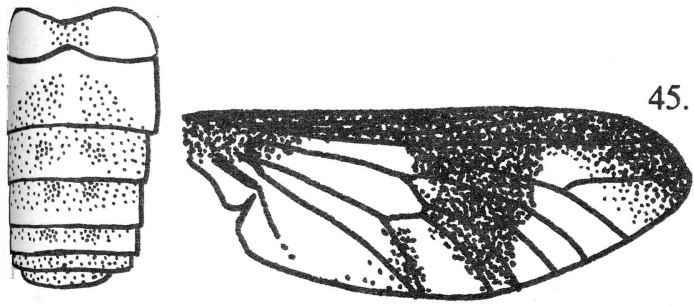

a. Thorax greenish gray with fuscous stripes; outer margin of crossband usually sinuous 


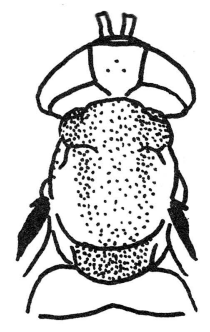

a

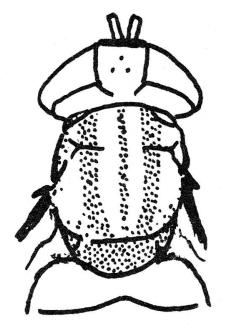

b
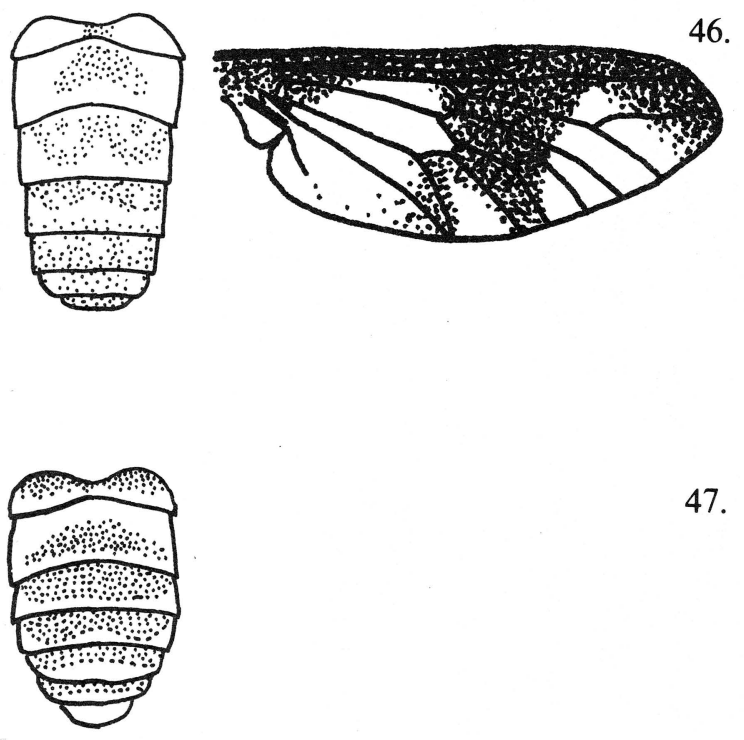

47. b. Thorax brown to yellowish in ground color with brown stripes; outer margin of crossband concave, straight, bowed, or sinuous

b. Dark median marking of second abdominal segment reaching only about half-way across segment; outer margin of crossband frequently bowed or sinuous; hind femora partly or all brown

a. Apical spot occupying upper half or second submarginal cell(smc2) and sharply outlined; fifth posterior cell (pc5) largely hyaline; smaller species averaging $8.25 \mathrm{~mm}$

.....dixianus Pechuman

a. Dark median marking of second abdominal segment reaching about two-thirds across segment; outer margin of crossband usually straight or somewhat concave; hind femora yellow

.....flavidus Wiedemann
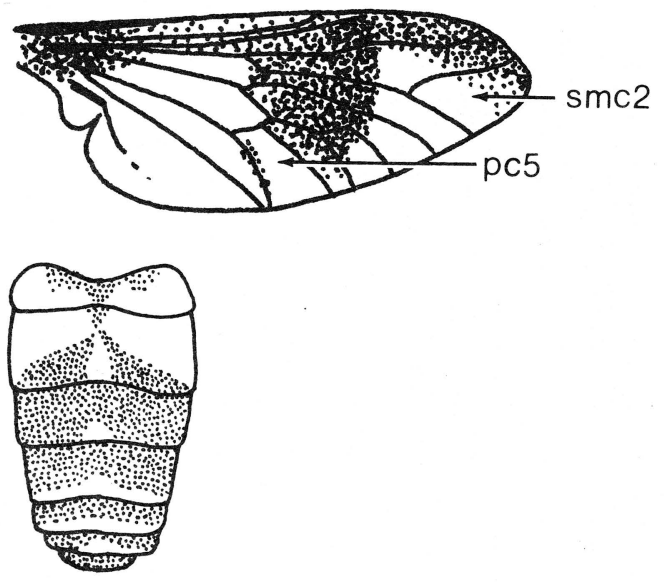

b. Apical spot indefinite in outline, extending into lower half of second submarginal cell as a paler infuscation which may continue into apical portions of first, second and third posterior cells; fifth posterior cell largely infuscated; larger species averaging $9.5 \mathrm{~mm}$

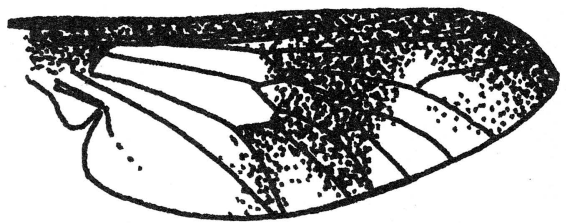




\section{MALES}

(C. bistellatus and C. dixianus not included)

1. a. Apex of wing beyond crossband hyaline

b. Apex of wing infuscated beyond crossband so that an apical spot is present

2. a. Frontoclypeus black with a midfacial pollinose stripe which begins below antennae and runs at least half way to the oral margin

..... 3

b. Frontoclypeus black or yellow without a midfacial pollinose stripe

3. a. Abdomen completely black

b. First 2 abdominal segments with small reddish or yellowish spots laterally

4. a. Fifth posterior cell with hyaline area at base

b. Fifth posterior cell infuscated at base

5. a. Outer margin of crossband straight or slightly and evenly bowed; crossband usually reaching hind margin of wing in fourth and fifth posterior cells in full intensity; hyaline area at base of fifth posterior cell large and sharply defined

.....carbonarius Walker

b. Outer margin of crossband not usually reaching wing margin in full intensity; hyaline area at base of fifth posterior cell usually not with clearly defined margin; apical area of wing sometimes dilutely infuscated

.....ater Macquart

6. a. Crossband broadly and distinctly reaching hind margin of wing; outer margin of crossband usually straight

..... cincticornis Walker

b. Crossband reaching hind margin of wing narrowly and indistinctly or not at all; outer margin of crossband usually irregular

7. a. Beard with many yellow hairs; yellow hairs frequently mixed with black hairs of thorax, legs, and abdomen; sometimes with traces of pale abdominal markings

exitans Walker

b. Beard wholly black; rarely with pale hairs on body or with traces of pale abdominal markings

mitis Osten Sacken

8.(3) a. Wing pattern saturate; lateral spots on first 3 abdominal segments barely indicated

....exitans Walker

b. Wing pattern dilute; lateral spots on first 2 abdominal segments distinct 
9. a. Yellow spots on mid-dorsal line of abdomen; both basal cells nearly clear; pleurae with 2 pale stripes

.....fulvistigma Hine

b. No mid-dorsal yellow spots on abdomen; both basal cells $3 / 4$ infuscated; pleurae unstriped

.....cuclux Whitney

10.(2) a. Wing markings faint; face often entirely black

b. Wing markings dark; frontoclypeus yellow in middle ..... nigribimbo Whitney

11. a. Thoracic stripes faintly distinct; rarely a spot at bifurcation of third longitudinal vein .....calvus Pechuman \& Teskey

b. Thoracic stripes obsolete; often a spot at bifurcation of third longitudinal vein

.....niger Macquart

12.(1) a. Frontoclypeus with a midfacial pollinose stripe which begins below antennae and runs at least half way to oral margin

b. Frontoclypeus without midfacial stripe, integument of face at least partly yellow

13. a. Abdomen without longitudinal stripes; usually with considerable yellow on abdomen; legs usually with much yellow; frontoclypeus usually black, sometimes partially or completely yellow

.....frigidus Osten Sacken

b. Abdomen with black or yellow longitudinal stripes

14. a. Abdomen yellowish with mid-dorsal black stripe .....dorsovittatus Hine

b. Abdomen black with a narrow yellowish mid-dorsal line and occasionally similar shorter sublateral lines

.....upsilon Philip

15.(12)a. Abdomen black with no yellow markings; hind femora black

b. Abdomen with yellow markings; hind femora variable

..... 16

16. a. Apical spot not covering all of second submarginal cell

b. Apical spot includes all of second submarginal cell .....brimleyi Hine

17. a. Hyaline triangle clear, restricted to apices of second and third posterior cells; thorax usually with at least a trace of a pale stripe above wing base; facial area with considerable yellow ..... moechus Osten Sacken

b. Hyaline triangle dilutely infuscated; no trace of a pale stripe above wing base; yellow of facial area restricted to a narrow stripe in center of frontoclypeus; pleurae with some pale markings; first 2 antennal segments, fore coxae and femora with considerable yellow 
18.(15)a. Crossband and apical spot broken by dilute areas along veins ..... shermani Hine

b. Crossband and apical spot not broken by dilute areas although entire wing may be pale

19. a. Wing pattern dilute and indefinite; hyaline triangle indicated by clear area along edge of crossband and not usually extending beyond center of third posterior cell; first antennal segment considerably swollen; brown species with no definite abdominal pattern although dark markings may be indicated by dark shadows

..... brunnes Hine

b. Wing pattern distinct; hyaline triangle open at hind margin of wing (except probably in bistellatus the male of which is undescribed); first antennal segment not especially swollen, often very slender

20. a. Black species; abdomen with a yellowish median longitudinal stripe, occasional specimens vary with a similar abbreviated stripe on each side; hyaline triangle crosses second longitudinal vein; apical spot rarely occupies more than half of second submarginal cell, often less

b. Not with above combination of characters ....univittatus Macquart ....2 21

21. a. Apical spot very little broader at its apex than at its origin, crossing upper branch of third longitudinal vein at its apex and occupying very little of the second submarginal cell

b. Apical spot considerably broadened towards its apex, crossing at least half of upper branch of third longitudinal vein

22. a. Hyaline triangle not reaching second longitudinal vein

..... sackeni Hine

b. Hyaline triangle reaching or crossing second longitudinal vein ....23

23. a. Frontoclypeus with a large black spot on each side

b. Frontoclypeus entirely yellow or, at most, with some dark shading around frontoclypeal pits

callidus Osten Sacken

24.(21)a. Abdomen bright yellow and black; large black figure of second abdominal segment broadly joined to black figure of first segment; median yellow triangles do not reach the anterior border of the segments; apical spot occupying one-half to twothirds of second submarginal cell

b. Not with above combination of characters

25. a. Abdomen with a sublateral row of black spots; median yellow triangles moderate in size; hyaline triangle extending beyond bifurcation, sometimes reaching second longitudinal vein 
b. Abdomen without a sublateral row of black spots; hyaline triangle ends at bifurcation

indus Osten Sacken

26. a. Apical spot filling about half or less of second submarginal cell

.....27

b. Apical spot filling all or nearly all of second submarginal cell, sometimes extending into first posterior cell

27. a. Frontoclypeus with a black spot on each side; hyaline triangle crosses second longitudinal vein

.....lateralis Wiedemann

b. Frontoclypeus entirely yellow; hyaline triangle does not cross second longitudinal vein

28. a. First basal cell infuscated, except for subhyaline area near apex; second basal cell at least half infuscated; hind femora usually partly black

.... dimmocki Hine

b. First basal cell usually not more than half and second basal cell one-third infuscated; hind femora often entirely yellow; dark markings on second abdominal segment not reaching the anterior margin

29. a. Thorax yellow or brownish in ground color with brown stripes

b. Thorax greenish gray with fuscous stripes

30. a. Outer margin of crossband nearly straight; ground color of abdomen rather uniformly yellow; legs yellow

.....flavidus Wiedemann

b. Outer margin of crossband sinuous; base of second abdominal segment often with a greenish cast; legs pale mahogany

..... reicherti Fairchild

31. a. Crossband dilute, base of discal cell nearly hyaline; ground color of abdomen bright yellow; hind femora entirely yellow

.....cursim Whitney

b. Crossband saturate or nearly so, discal cell not paler at base; ground color of abdomen dull yellow; hind femora variable

32. a. Hind femora usually dark at base; a black spot beneath scutellum; dark abdominal markings usually saturate

......pudicus Osten Sacken

b. Hind femora usually entirely yellow; black spot beneath scutellum very pale or absent; dark abdominal markings often faded

celatus Pechuman

33.(26)a. Hyaline triangle crosses second longitudinal vein; yellow species with black abdominal markings not in the form of stripes

b. Not with above combination of characters 
34. a. Second abdominal segment with 2 oblique spots which frequently are joined to form a single inverted "V"

.....geminatus geminatus Wiedemann

b. Second abdominal segment completely yellow or with traces of 2 spots at posterior margin

..... impunctus Krober

35. a. Hyaline triangle reaches or nearly reaches second longitudinal vein if subhyaline beyond bifurcation of third longitudinal vein; predominantly black species with pale abdominal markings reduced

.... 38

b. Hyaline triangle scarcely extends beyond bifurcation of third longitudinal vein; predominantly yellowish species with dark abdominal markings

36. a. Abdomen with a median yellow stripe with a longitudinal black band on each side; lateral margins of segments narrowly yellow .....macquarti Philip

b. Abdomen yellow with 4 more or less complete rows of black spots

37. a. Ground color of thorax and scutellum yellow .....vittatus vittatus Wiedemann

b. Ground color of thorax plumbeus, scutellum sometimes with some yellow

.....aberrans Philip

38. a. Blackish species, with reduced pale abdominal markings

b. Yellow species with black abdominal markings

39. a. Thorax without a yellow stripe above wing base; lower border of second basal cell not more heavily infuscated than adjoining portion of cell

.....dacne Philip

b. Thorax with a yellow stripe on each side above wing base; lower border of second basal cell infuscated; abdomen with a dull yellowish median stripe, frequently with a shorter stripe on each side

obsoletus obsoletus Wiedemann

40. a. Frontoclypeus with a large dark spot on each side and cheeks with considerable black

b. Frontoclypeus and cheeks mostly yellow

41. a. No sublateral spots on first and second tergites; second basal cell not more than half infuscated sometimes almost entirely clear; hyaline triangle rounded at apex

.....pikei Whitney

b. Sublateral stripes completely cross first two tergites; second basal cell largely infuscated with a subhyaline area near apex; hyaline triangle pointed at apex 
b. Second basal cell largely infuscated; thoracic stripes indistinct, greenish

Chrysops aberrans Philip

This species may be found in the Northern and Eastern Panhandles of the state.

\section{Chrysops ater Macquart}

Seasonal Range-14-V to 3-VI.

Distribution-POCAHONTAS, Cranberry Glades, 1,2-VI-55, HW, USNM. PRESTON, Cranesville Swamp, 3-VI-76, BD, WVU. RANDOLPH, Sinks of Gandy, 1-VI-77, JA, WVU. TUCKER, Blackwater Falls St. Pk., 21-V-77, JA, WVU.

$C$. ater is a northern species, previously unknown south of ROCKBRIDGE, VA, SOMERSET, PA, AND JEFFERSON, OH. In West Virginia this species is common locally in isolated mountain bogs and seems to be restricted to these habitats.

Chrysops beameri Brennan

Seasonal Range-7-VII (VII to 25-VIII).

Distribution-MASON, McClintic Wildlife Sta., 7VII-77, JH, WVDA.

Specimens collected in West Virginia are not typical of the species; thus their true identity is in question. However, the species has been taken in all of the contiguous states except KY and should occur throughout West Virginia.

Chrysops bistellatus Daecke

This is primarily a coastal species but may occur in the Eastern Panhandle of West Virginia.

Chrysops brimleyi Hine

Most records of this species are from coastal areas; the species may occur in the state's Eastern Panhandle.

Chrysops brunneus Hine

Reported catches from $\mathrm{OH}, \mathrm{PA}, \mathrm{MD}$, and VA suggest occurrence of this species in West Virginia.

Chrysops callidus Osten Sacken

Seasonal Range-17-V to 3-VIII (6-V to 6-IX).

Distribution-BERKELEY, Sleepy Creek Publ. Hunt. and Fish. Area, 2-VIII-75, BD, WVU. BRAXTON, Sutton Lake, 3-VI-77, LB, WVU. BROOKE, Castleman Run Lake, 9-VI-76, BD, WVU. CABELL, Barboursville, 1-VI-78, JH, WVDA. FAYETTE, Rainelle, 29-VII-77, TK, WVU. GILMER, Cedar Ck. St. Pk., 4-VI-77, LB, WVU. GRANT, Greenland Gap, 24-V-77, JA and LB, WVU. GREENBRIER, Clendinsville, 18-VI-76, JH, WVDA. HAMPSHIRE, Capon Bridge, 24-VI-75, CC, WVDA. HANCOCK, Tomlinson Run St. Pk., 9VI-76, LB and BD, WVU. HARDY, Lost River St. Pk., 19-VI-51, KVK, KVK. HARRISON, Hepzibah, 17-VI-76, TM, WVU. JACKSON, Ripley, 2-VI-75, JH, WVDA. JEFFERSON, Shannondale, 1-VI-77, JH, WVDA. KANAWHA, Kimberly Rd., 17-VI-76,
SF, WVDA. LEWIS, Jackson's Mill, 28-VII-75, JH, WVDA. LINCOLN, Big Ugly Publ. Hunt. Area, 2 VIII-78, LB, WVU. MARSHALL, Burches Run Lk., 25-V-77, JH, WVDA. MASON, Point Pleasant, 5-VI75, JH, WVDA. MINERAL, New Creek, 11-VI-76, BD, WVU. MONONGALIA, Dent's Run, 17-V-75, BD, WVU. OHIO, Bear Rocks Lk., 25-V-77, JH, WVDA. PENDLETON, Brandywine Lk., 22-VII-77, LB, WVU. PLEASANTS, Bens Run, 25-V-77, JH, WVDA. PRESTON, Reedsville, 24-VII-75, BD, WVU. RANDOLPH, Gilman, 10-VI-76, PV, WVDA. RITCHIE, 26-V-76, TM, WVU. ROANE, 2 mi. W. Spencer, 22-V-78, LB, WVU. SUMMERS, Bluestone Lk., 2-VI-77, JA, WVU. TYLER, Pursley, 25-V-77, JH, WVDA. UPSHUR, Buckhannon, 12-VI-76, JH, WVDA. WETZEL, Lewis Wetzel Publ. Hunt. Area, 18-VI-76, BD and LB, WVU. WOOD, Parkersburg, 28-V-76, TM, WVU.

This is one of the more abundant and pestiferous Chrysops in West Virginia. The importance of this species is increased because of its long seasonal occurrence; it remains abundant after the decline of the early season species complex (C. calvus, carbonarius, cincticornis, cuclux, indus and niger). The numbers of $C$. callidus remain high throughout the mid-June surge of other tabanid species (C. geminatus, impunctus, lateralis, macquarti, univittatus, vittatus and various Tabanus sp.), but decline rapidly in late June and early July.

On 14 June 1976, an area near Core in Monongalia County was surveyed at the request of the property owner who experienced acute sensitivity to deerflies, becoming drowsy and languid after receiving two or three bites. A three-day survey of the area, using sweep net sampling and $\mathrm{CO}_{2}$ baited malaise traps, revealed $C$. callidus as the only Chrysops present. Local control of tabanids in this case would have been highly desirable.

Chrysops calvus Pechuman and Teskey

Seasonal Range-20-V to 25-VI (1-V).

Distribution-CALHOUN, Rt. 33, 2 mi. E. county line, 27-V-78, LB, WVU. MARSHALL, Burches Run Lk., 25-V-77, JH, WVDA. MINERAL, New Creek, 11-VI-76, BD, WVU. MONONGALIA, 31-V-75, LB, WVU. POCAHONTAS, Cranberry Glades, 21-VI-75, BD, WVU (Allen and Pechuman, 1977). PRESTON, Bruceton Mills, 1-VI-65, WJ, CU, Paratype (Pechuman and Teskey, 1967). RANDOLPH, Rt. 219, 5 mi. N. Elkins, 5-VI-76, BD, WVU. ROANE, 31-V. 58, RW, OSU, Paratype (Pechuman and Teskey. 1967). SUMMERS, Pipestem St. Pk., 9, 10-VI-76, JH. WVDA. TUCKER, Rt. 217, W. Slope Backbone Mt. 14-V-76, BD, WVU. WEBSTER, Cranberrs 
Campground, 20-VI-75, BD, WVU. WYOMING, Pineville, 20-V-77, LB, WVU.

This species is generally distributed but not very abundant. It has often been collected with its close relative, $C$. niger, although it occurs in locations where C. niger was not taken. The specimens from PRESTON and ROANE were designated paratypes by Pechuman and Teskey (1967).

hrysops carbonarius Walker

Seasonal Range-28-V to 1-VIII (2-V).

Distribution-BERKELEY, Sleepy Ck. Publ. Hunt. and Fish. Area, 28-V-76, BD, WVU. GREENBRIER, S. Fork Cherry River, 11-VII-76, BD, WVU. JEFFERSON, Shannondale, 1-VI-77, JH, WVDA. PENDLETON, Seneca Campground, 11-VII-76, BD, WVU. POCAHONTAS, Deer Ck./Rt. 28, 1-VI-77, JA, WVU. PRESTON, Eglon, 28-V-75, RW1', WVU. RANDOLPH, Sinks of Gandy, 1-VI-77, JA, WVU. SUMMERS, Pipestem St. Pk., 9-VI-76, JH, WVDA. TUCKER, Dolly Sods, 3-VII-75, LB AND DB, WVU. WEBSTER, Cranberry Campground, 20-VI-75, BD, WVU.

This species occurs primarily in the Eastern Panhandle and central mountainous areas. It is usually important in the spring as a part of an emerging wave or complex of species (see C. callidus discussion). Only in WEBSTER did this species make up as much as 45 percent of the Chrysops collected.

hrysops celatus Pechuman

Seasonal Range-2-VI (26-V to 8-VII).

Distribution-SUMMERS, Bluestone Lk., 2-VI-77, JA, WVU.

Scattered records for this species were reported from NY to AL. Despite this wide distribution, these deerflies seem very local in occurrence.

hrysops cincticornis Walker

Seasonal Range-23-IV to 3-VIII (20-IV).

Distribution-BARBOUR, Pleasant Ck., 23-IV-77, JA, WVU. BERKELEY, Sleepy Ck. Publ. Hunt. and Fish. Area, 3-VIII-75, BD, WVU. BROOKE, Castleman Run Lk., 9-VI-76, BD, WVU. GRANT, Sherr, 24-V-77, LB, WVU. HAMPSHIRE, Grace, 20VI-78, WVDA. HANCOCK, Tomlinson Run St. Pk., 9-VI-76, BD, WVU. JEFFERSON, Shannondale, 1VI-77, JH, WVDA. MASON, McClintic Wildlife Sta., 6-VI-78, JH, WVDA. MINERAL, New Creek, 11-VI76, BD, WVU. MONONGALIA, Morgantown, 28-V74, GP, ND. McDOWELL, Panther St. For., 21-V-77, LB, WVU. OHIO, Bear Rock Lk., 25-V-77, JH, WVDA. POCAHONTAS, Cranberry Glades, 21-VII75, SB, VPI (Allen and Pechuman, 1977). PRESTON, Muddy Creek, 1-VII-75, BD, WVU. SUMMERS, Pipestem St. Pk., 9,10-VI-76, JH, WVDA. WEBSTER, Cranberry Campground, 11-VII-76, BD, WVU. WOOD, Waverly, 25-V-77, JH, WVDA.

This species is not abundant and ranks close to $C$. carbonarius in numbers collected. However, $C$. cincticornis is more evenly distributed throughout the state and forms part of the spring complex of deerflies. Chrysops cuclux Whitney

Seasonal Range-20-V to 21-VI (8-V to 22-VII).

Distribution-BERKELEY, Sleepy Ck. Publ. Hunt. and Fish. Area, 28-V-76, BD, WVU. BROOKE, Castleman Run Lk., 9-VI-76, BD and LB, WVU. HANCOCK, Tomlinson Run St. Pk., 9-VI-76, LB, WVU. MASON, McClintic Wildlife Sta., 21-V-76, BD, WVU. MONONGALIA, Joe's Run, 20-V-77, JA, WVU. PRESTON, Cranesville Swamp, 3-VI-76, BD, WVU. POCAHONTAS, Cranberry Glades, 21-VI-77, SB, VPI (Allen and Pechuman, 1977). RANDOLPH, Rt. 219, 5 mi. N. Elkins, 5-VI-76, BD, WVU. TUCKER, Dolly Sods, 10-VI-77, JA, WVU.

Records show a general distribution at lower elevations; only in the higher elevations were series taken indicating a greater abundance of this species in these areas.

Chrysops cursim Whitney

This is not a common species, and of the surrounding states it is found only in PA and MD. However, it is found scattered throughout eastern North America and thus may occur in West Virginia.

\section{Chrysops dacne Philip}

This species has been captured in PA, MD, and VA counties near the West Virginia borders, indicating that it probably occurs in West Virginia also.

Chrysops delicatulus Osten Sacken

PORTAGE, OH, and PRINCE GEORGES, MD, are the only two records from the surrounding states; the species is more common northward.

Chrysops dimmocki Hine

This species probably occurs in West Virginia as it has been captured in all states contiguous to West Virginia, except KY.

Chrysops dixianus Pechuman

VA records mark the northernmost known range for this newly described species. No specimens have been taken in West Virginia.

Chrysops dorsovittatus Hine

This species is uncommon, and only two county records are known from the surrounding states: MD and VA.

Chrysops exitans Walker

Seasonal Range-3-VII (27-V to late VII).

Distribution-TUCKER, Dolly Sods, 3-VII-75, LB and DB, WVU (male).

The capture of this specimen marks a new southern range extension for this species. It had previously been found as far south as MONROE, PA, and OCEAN, NJ. Pechuman agrees that its occurrence in West Virginia represents a disjunct population. More collecting in the areas between the capture localities should confirm this opinion. 


\section{Chrysops flavidus Wiedemann}

Seasonal Range-26-VI to 2-VIII (9-VI to 20-VIII). Distribution-BERKELEY, Sleepy Creek Publ. Hunt. and Fish. Area, 2-VIII-75, BD, WVU. KANAWHA, Kanawha Station, 26-VI-18, SR, USNM. LEWIS, Jackson's Mill, 26-VII-77, JH, WVDA. MASON, McClintic Wildlife Sta., 2-VIII-78, Butler, WVU. TUCKER, 28-VIII-77, BN, WVU.

Though not a common species, C. flavidus is found scattered through all of the surrounding states and is reportedly more abundant near the Atlantic coast.

Chrysops frigidus Osten Sacken

This is a northern species with present southernmost records from PORTAGE, OH, and CENTRE, PA, both near but still north of West Virginia's northern borders.

Chrysops fulvistigma Hine

This is primarily a southern species, approaching its northern limits in MD and NJ. It is not commonly collected anywhere in its known range but may occur in West Virginia.

Chrysops geminatus Wiedemann

Seasonal Range-25-VI to 9-VIII (26-V to 19-VIII). Distribution-BRAXTON, Sutton Lk., VIII-7-75, BD, WVU. BERKELEY, Sleepy Creek Publ. Hunt. and Fish. Area, 23-VII-76, BD, WVU. GREENBRIER, S. Fk. Cherry River, 11-VII-76, LB \& BD, WVU. HAMPSHIRE, Capon Bridge, 16-VII77, PV, WVDA. JEFFERSON, Shannondale, 27-VII78, CC, WVDA. MINERAL, New Creek, 25-VI-76, BD, WVU. MONONGALIA, 1-VII-75, BD, WVU. MORGAN, Cherry Run, 5-VII-78, CC, WVDA. PENDLETON, Spruce Knob, 6-VIII-60, GW, CM. POCAHONTAS, Cranberry Glades, 16-VII-55, CWS, USNM. PRESTON, Chestnut Ridge, 1-VII-75, BD, WVU. RANDOLPH, Rt. 250 near Cheat Mt., 6VIII-60, HM and GW, CM. SUMMERS, Pipestem St. Pk., 28-VII-76, TM, WVU. WEBSTER, Bergoo, 13-VII-78, JH, WVDA. WETZEL, Lewis Wetzel Publ. Hunt. Area, 3-VII-78, LB, WVU.

C. geminatus was expected to occur in West Virginia prior to this study because of records from contiguous states. No specimens have been taken from the western geographical zones of West Virginia.

Chrysops hinei Daecke

This species is uncommon in the neighboring states, but it has been taken in MD and VA.

\section{Chrysops impunctus Krober}

Seasonal Range-25-VI to 15-VII (17-VII).

Distribution-BRAXTON, Sutton Lk., 8-VII-75, BD, WVU. MINERAL, New Creek, 25-VI-76, BD, WVU. MONONGALIA, Chestnut Ridge, 15-VII-77, JA, WVU. McDOWELL, Panther St. For., 10-VII-77, LB, WVU. POCAHONTAS, "July," CS, WVU. PRESTON, Brandonville Pike, 1-VII-75, BD, WVU. WEBSTER, Bergoo, 13-VII-78, JH, WVDA.

This species is often caught along with C.geminatus but is less abundant, having a more spotty distribution. Until recently this species has been treated as a subspecies of $C$. geminatus. However, the characters are so constant that it is treated here as a separate species.

Chrysops indus Osten Sacken

Seasonal Range-12-V to 8-VIII (1-V)

Distribution-BARBOUR, Pleasant Ck., 12-V-77. LB, WVU. BERKELEY, Sleepy Creek Publ. Hunt. and Fish. Area, 28-V-76, BD, WVU. BROOKE. Castleman Run Lk., 9-VI-76, BD, WVU. HANCOCK, Tomlinson Run St. Pk., 9-VI-76, BD, WVU. GRANT, Sherr, 12-V-77, LB, WVU. HARDY. Warden Lk., 24-VII-76, BD, WVU. MARSHALL, Burches Run Lk., 21-VI-76, SB, VPI (Allen and Pechuman, 1977). MINERAL, New Creek, 11-VI-76, BD, WVU. MONONGALIA, Dent's Run, 22-V-75, DB, WVU. OHIO, Bear Rocks Lk., 25-V-77, JH, WVDA. POCAHONTAS, Cranberry Glades, 1-VI55, HW, USNM. PRESTON, Reedsville, 17-VI-75, LB, WVU. RANDOLPH, Sinks of Gandy, 1-VI-77, JA, WVU. SUMMERS, Pipestem St. Pk., 10-VI-76, JH, WVDA. TUCKER, Fisher Run, 7-VII-61, PH, USNM.

Records from West Virginia and MD mark the southernmost range of this species, although disjunct populations may occur in VA and NC. It is most abundant in the spring, but will readily attack man during the remainder of the season when it is less abundant.

Chrysops lateralis Wiedemann

Seasonal Range-25-VI to 9-VIII (7-VI).

Distribution-GREENBRIER, S. Fk. Cherry River, 11-VII-76, BD, WVU. MINERAL, New Creek, 25-VI76, BD, WVU. PENDLETON, Spruce Knob 5,6,7VIII-60, GW, CM. POCAHONTAS, Hillscreek Falls, 12-VII-76, BD, WVU. PRESTON, Brandonville Pike, 1-VII-75, BD, WVU. RANDOLPH, Rt. 250 near Cheat Mt., 6-VIII-60, HM and GW, CM. TUCKER, Dolly Sods, 3-VII-75, LB and DB, WVU.

A series of ten females taken in GREENBRIER represents the southernmost distribution and a range extension for this species. Typical of northern species in West Virginia, $C$. lateralis is restricted to the mountainous areas of the state, being a common pestiferous species.

Chrysops macquarti Philip (Synonym prior to 196l C. univittatus of authors but not Macquart)

Seasonal Range-25-V to 18-VIII (11-V to 1-IX). Distribution-BRAXTON, Sutton Lk., 3-VI-77, LB, WVU. BROOKE, Castleman Run Lk., 9-VI-76, BD, WVU. FAYETTE, 30-VI-76, BD, WVU. HAMPSHIRE, 2 mi. E. Capon Bridge, 3-VII-75, BD, WVU. HARDY, Warden Lk., 24-VII-76, LB, WVU. JEFFERSON, Shannondale, 28-VI-78, CC, WVDA. MARION, Mannington, 6-VII-76, TM, WVU. 
MASON, McClintic Wildlife Sta., 7-VII-77, JH, WVDA. MERCER, Athens, 29-VI-76, BD, WVU. MINERAL, New Creek, 11-VI-76, BD, WVU. MINGO, Williamson, 19-VII-76, BD, WVU. MONONGALIA, 28-VI-75, LB, WVU. OHIO, Bear Rocks Lk., 25-V-77, JH, WVDA. PENDLETON, Ft. Seybert, 15-VII-76, WN and KE, WVDA. POCAHONTAS, Cranberry Glades, 20-VI-75, BD, WVU. PRESTON, Brandonville Pike, 1-VII-75, BD, WVU. RANDOLPH, Laurel Fk. Campground, 9VIII-75, BD, WVU. SUMMERS, Pipestem Lk., 28VI-76, JH, WVDA. TAYLOR, 25-VI-76, TM, WVU. WEBSTER, Cranberry Campground, 20-VI-75, BD, WVU. WETZEL, Lewis Wetzel Publ. Hunt. Area, 18VI-76, BD, WVU.

This species is a successful biter because of its silent approach. Fifty percent of the records occur in July, and it has a general distribution throughout West Virginia and the surrounding states.

hrysops mitis Osten Sacken

This is a northern species not known south of NY except by a few unconfirmed reports. Disjunct colonies may occur in West Virginia.

hrysops moechus Osten Sacken

Seasonal Range-21-V to 15-VIII.

Distribution-BOONE, Fork Cr. Publ. Hunt. Area, 14-VI-78, LB, WVU. BROOKE, Castleman Run Lk., 9-VI-76, BD, WVU (male). GILMER, Cedar Ck. St. Pk., 4-VI-77, LB, WVU. HAMPSHIRE, Capon Bridge, 16-VII-75, PV, WVDA. HARDYHAMPSHIRE, Potomac River, 10-VII-76, DB, WVU. HARRISON, Near Salem along Ten Mile Ck., 21-VI-76, DB, WVU. LEWIS, Jackson's Mill, 27-VII77, JH, WVDA. LINCOLN, Big Ugly Publ. Hunt. Area, 2-VIII-78, LB, WVU. MINERAL, Burlington, 15-VI-36, GK, CM. PRESTON, Clifton Mills, 24-VI77, JA, WVU. RITCHIE, North Bend St. Pk., 23-VI77, LB, WVU. WAYNE, Cabwaylingo St. For., 21-V77, LB, WVU.

This species may become locally abundant, especially near streams with overhanging vegetation. The adults are especially sexually dimorphic.

hrysops montanus Osten Sacken

Seasonal Range-9-VI-76 (27-V to 11-VIII).

Distribution-HANCOCK, Tomlinson Run St. Pk., 9-VI-76, BD, WVU.

This species occurs commonly in NY but may be quite local there and elsewhere. It has been taken in $\mathrm{MD}, \mathrm{DC}, \mathrm{VA}, \mathrm{PA}$, and $\mathrm{OH}$.

hrysops niger Macquart

Seasonal Range-12-V to 20-IX.

Distribution-BARBOUR, Pleasant Ck., 12-V-77, LB, WVU. BERKELEY, Inwood, 1-VI-77, JH, WVDA. BROOKE, Castleman Run Lk., 9-VI-76, LB, WVU. GILMER, Stumptown, 27-V-78, LB, WVU. GRANT, Scherr, 24-V-77, LB, WVU. HAMPSHIRE-
HARDY, Potomac River, 21-VI-76, DB, WVU. HANCOCK, Tomlinson Run St. Pk., 9-VI-76, LB, WVU. JEFFERSON, Charles Town, 1-VI-77, JH, WVDA. MASON, Point Pleasant, 5-VII-75, JH, WVDA. MINERAL, New Creek, 11-VI-76, BD, WVU. MONONGALIA, Morgantown, 28-V-74, GP, ND. MORGAN, Cherry Run, 27-VI-78, CC, WVDA. OHIO, Bear Rocks Lake, 25-V-77, JH, WVDA. PENDLETON, Seneca Campground, 23-VI-76, BD, WVU. PLEASANTS, Bens Run, 25-V-77, JH, WVU. POCAHONTAS, Cranberry Glades, 21-VI-75, BD, WVU. PRESTON, Reedsville Exp. Sta., 9-VI-75, LB, WVU. RANDOLPH, Rt. 219, 5 mi. N. Elkins, 5-VI76, BD, WVU. RITCHIE, Lynn Camp Rd. near Pennsboro, 26-V-76, TM, WVU. SUMMERS, Pipestem St. Pk., 9-VI-76, JH, WVDA. TYLER, Pursley, 25-V-77, JH, WVDA. WAYNE, Fort Gay, 2VII-71, RT, WVU. WEBSTER, Cranberry Campground, 20-VI-75, BD, WVU. WETZEL, Lewis Wetzel Publ. Hunt. Area, 18-VI-76, BD, WVU. WIRT, VI-56, HP, WVU. WOOD, Rockport, 11-VI54, HF, MSU.

C. niger is one of the four most abundant and widespread tabanid species in West Virginia. Philip (1947) reported records from all of the surrounding states. Pechuman, in 1964, was aware of West Virginia records while compiling data for the description of $C$. calvus and subsequently re-checked the earlier records for the possibility that these might be $C$. calvus.

Chrysops nigribimbo Whitney

Other than records from two locations in MD and one in DC, this species is not known from the remaining states contiguous to West Virginia. It may occur in the Eastern Panhandle.

Chrysops obsoletus obsoletus Wiedemann

Although Philip (1947) lists this species from OH, PA, $\mathrm{MD}$, and DC, Pechuman knows only of confirmed records from PA, NJ, NY, MD, and VA. The problem results from recent name changes and the separate distribution of the subspecies lugens. Chrysops lugens of authors, not Wiedemann, is actually $C$. dacne Philip, and $C$. ultimus Whitney is a synonym of $C$. lugens lugens Wiedemann. Philip clarified this matter when he described $C$. dacne. MONTGOMERY, MD, currently the nearest record, lies less than twenty miles east of West Virginia's Eastern Panhandle.

Chrysops parvulus Daecke

This species is common only in small localized areas, ranging from $\mathrm{NJ}$ to $\mathrm{FL}$ and west to $\mathrm{AR}$.

Chrysops pikei Whitney

Seasonal Range-23-VI to 28-VII (30-V to 21-VIII). Distribution-BROOKE, Bethany, 10-VI-75, JH, WVDA. HAMPSHIRE, Grace, 28-VII-77, WM and KE, WVDA. KANAWHA, Kanawha Sta. 1918, SR, USNM. LEWIS, Jackson's Mill, 28-VII-75, JH, WVDA. RITCHIE, North Bend St. Pk., 23-VI-77, LB, WVU. 
The national distribution of $C$. pikei was described by Philip (1965) as having an easternmost range along a line from Ontario to FL, which would include the western zones of this state. Pechuman (1973) mentions records from VA and suggests that it has probably moved north into VA during the past 40 years, leaving the mountainous areas of the eastern United States devoid of this species.

Chrysops pudicus Osten Sacken

This is primarily a coastal species, although it has been recorded inland. Again the nearby record from MD makes this species a likely addition to this state's list of records.

Chrysops reicherti Fairchild

The nearest confirmed records of this species are known from MD, VA, and IN. This species has not been reported north of MD and throughout its range occurs in highly restricted areas, or rather very locally.

Chrysops sackeni Hine

Seasonal Range-8-VI to 10-VII (5-VI to 25-VII). Distribution-BERKELEY, Sleepy Creek Publ. Hunt. and Fish. Area, 8-VI-77, HT and LLP, CU. PRESTON, Cranesville Swamp, 10-VI-77, JA and TM, WVU. TUCKER, Dolly Sods, 3-VI-75, LB, WVU. WEBSTER, Cranberry Campground, 20-VI75, BD, WVU.

These West Virginia records represent the southern range for this species as it has not been taken south of $\mathrm{MD}, \mathrm{OH}$, and IN except for a possible record from NC. It occurs in the mountainous areas of West Virginia, characteristic of many northern species occurring in this state.

Chrysops sequax tau Philip

Seasonal Range-10-VII to 18-VIII (28-VIII).

Distribution-BERKELEY, Sleepy Creek Publ. Hunt. and Fish. Area, 24-VII-76, BD, WVU. BROOKE, Bethany, 10-VII-75, JH, WVDA. HAMPSHIRE, Grace, 28-VII-77, CC, WVDA. SUMMERS, Pipestem St. Pk., 28-VII-76, TM, WVU.

Very little information pertaining to $C . s$. tau is available due to its recent separation from C. s. sequax Williston. Pechuman (1973) explains that all "specimens reported as $C$. sequax from east of $\mathrm{OH}$, including those of McAtee and Walton (1918) from MD and VA are either $C$. beameri or $C$. hinei." Specimens from BERKELEY show unusual variations from the described $C$. $s$. tau subspecies because they possess extremely short pollinose projections on the frontoclypeus. This projection is the key character separating this subspecies from $C$. $s$. sequax. The BERKELEY specimens also show reduced sublateral abdominal spots, and one specimen even possesses a yellow callus without black spots near the frontoclypeal pits.

Chrysops shermani Hine

Seasonal Range-10-VI to 25-VIII.

Distribution-BERKELEY, Sleepy Creek Publ.
Hunt. and Fish. Area, 2,3-VIII-75, BD, WVU. GREENBRIER, S. Fork Cherry River, 11-VII-76, BD, WVU. HANCOCK, Tomlinson Run St. Pk., 9VI-76, BD, WVU. MINERAL, New Creek, 25-VI-76, BD, WVU. POCAHONTAS, Cranberry Glades, 16VII-52, CWS, USNM. PRESTON, Cranesville Swamp, 10-VI-77, LB, WVU. RANDOLPH, Laurel Fork Campground, 8,9-VIII-75, BD, WVU.

This species is found primarily in the hilly and mountainous areas of the state, and is also known from PA and VA.

Chrysops striatus Osten Sacken

Philip (1947) published records from PA, VA, DC, and $\mathrm{OH}$. However, this report was corrected in 1950, and all but the $\mathrm{OH}$ records proved to be $C$. aberrans (Philip 1950b). This is a northern species, and records closest to West Virginia are from extreme northern counties in $\mathrm{OH}$ and PA which delimit its southern range. Disjunct colonies might occur in West Virginia's mountainous regions.

Chrysops univittatus Macquart (Prior to 1961, C. - univittatus of authors, not Macquart, was the name used for C. macquarti Philip)

Seasonal Range-9-VI to 18-VIII (26-V to 9-IX). Distribution-BERKELEY, Sleepy Creek Publ. Hunt. and Fish. Area, 2-VIII-75, BD, WVU. BROOKE, Bethany, 10-VII-75, JH, WVDA. GREENBRIER, Sherwood Lake, 12-VIII-75, BD, WVU. HAMPSHIRE, Grace, 28-VII-77, CC, WVDA. HANCOCK, Tomlinson Run St. Pk., 9-VI76, BD, WVU. HARDY, Warden Lk., 24-VII-76, BD, WVU. KANAWHA, SR, USNM. LEWIS, Jackson's Mill, 24-VII-78, JH, WVDA. MASON, Rt. 2, S. Co. Line, eclosed 8-VII-76, BD, WVU. MINERAL, New Creek, 11-VI-76, BD, WVU. MINGO, 5 mi. N. Williamson, 19-VII-76, BD, WVU. MONONGALIA, Dent's Run, 17-VI-75, BD, WVU. PRESTON, 24-VI75, BD, WVU. OHIO, Bear Rocks Lk., 17-VIII-77, JH, WVDA. SUMMERS, Pipestem St. Pk., 9-VI-77, JH, WVDA. WEBSTER, Cranberry Campground, 11-VII-76, BD, WVU. WETZEL, Lewis Wetzel Publ. Hunt. Area, 18-VI-76, BD, WVU.

This species was listed from all of the contiguous states by Philip (1947), although it was listed as C. wiedemanni. It is widespread throughout West Virginia, but large numbers were rarely collected except at a few locations from late June through late July.

C. univittatus is a successful biter, able to approach noiselessly. It is usually not detected until one experiences the distinctive sharp pain produced when this insect feeds.

Chrysops upsilon Philip

This southeastern species is not known from West Virginia, although it might occur in the lower areas. Records are known from MD, VA, and KY. 
Chrysops vittatus Wiedemann

Seasonal Range-8-VI to 18-VIII (4-V to 9-IX).

Distribution-BARBOUR, Philippi, 22-VII-61, DV, VPI. BERKELEY, Sleepy Creek Publ. Hunt. and Fish. Area, 2-VIII-75, BD, WVU. HAMPSHIRE, Capon Bridge, 6-VIII-77, PV, WVDA. HANCOCK, Tomlinson Run St. Pk., 9-VI-76, BD, WVU. HARDY, Moorefield, 30-VII-75, PV, WVDA. HARRISON, 12-VII-75, BD, WVU. LINCOLN, Garrets Bend, 16-VIII-77, KH, WVDA. MASON, McClintic Wildlife Sta., 7-VII-77, CC, WVDA. MINERAL, New Creek, 9-VI-76, BD, WVU. MINGO, 5 mi. N. Williamson, BD and PF, WVU. MONONGALIA, Dents Run, 17-VI-75, BD, WVU. PENDLETON, Germany, 16-VII-75, JH, WVDA. POCAHONTAS, Cranberry Glades, 9-VIII-76, LB, WVU. PRESTON, 31-VII-75, BD, WVU. RANDOLPH, Shaver's Fk. near Cheat Bridge, 15VII-36, GK, CM. TUCKER, Olson Bog, 10-VIII-76, BD, WVU. WEBSTER, Cowen, VII-34, LLP, LLP.

Pechuman (1972) reports this species to be the most abundant in the low lying wooded areas in NY. In West Virginia it is present throughout the state. In fact, $C$. vittatus scores the highest Index of Abundance rating of all Chrysops, a conclusion also agreeing with observations from PA, VA, and MD.

Genus NEOCHRYSOPS

Neochrysops globosus Walton

This species, the only member of the genus, is known from seven specimens collected in MD (type), DE, AL, TN, and MS (Goodwin, 1976b). Such a sporadic and wide distribution may include West Virginia.

Subfamily TABANINAE Stone

Tribe Diachlorini

Genus DIACHLORUS

Diachlorus ferrugatus (Fabricius)

This tabanid is most common in coastal areas from FL to NJ. Specimens from inland locations in KY and IN indicate that it may well occur in West Virginia.

Genus MICROTABANUS

Microtabanus pygmaeus (Williston)

This is another "rare" tabanid and the only member of this genus. It is known from DE, VA, NC, and, possibly, NY. Philip et al. (1973) reported that in FL, M. pygmaeus is a nocturnal feeder and suggested that it feeds on birds and mice on Navarre Beach. Its nocturnal habits may explain its rare occurrence in collections and its spotty distribution.

Genus CHLOROTABANUS Lutz

Chlorotabanus crepuscularis (Bequaert)

The range of this tabanid is sporadic from DE and TN south to FL and west to TX. The nearest records are from MD and VA. Thus, it may occur in West Virginia. Because of its crepuscular habits, this fly is not often collected by conventional tabanid survey techniques.

Genus LEUCOTABANUS Lutz

Leucotabanus annulatus (Say)

Seasonal Range-2-VIII (15-VII to 20-VIII).

Distribution-LINCOLN, Big Ugly Publ. Hunt. Area, 2-VIII-78, LB, WVU.

This species was previously known from scattered records from MD, VA, and KY. Philip also published records from OH and PA (Philip, 1966 and 1950a, b, respectively). The WV specimen was swept at dusk, indicating crepuscular or nocturnal behavior for $L$. annulatus.

Tribe Haematopotini Meigen

Genus HAEMATOPOTA Meigen

Haematopota rara Johnson

Seasonal Range-10-VI (4-VI to 5-VII).

Distribution-MONONGALIA, Joe's Run, 10-VI76, BD, WVU.

This distinctive, uncommon, but widespread species has previously been reported from all of the surrounding states except KY. Another species, $H$. champlaini, has been collected in DAUPHIN, PA. $H$. champlaini is known only from female specimens from PA and RI. These two Haematopota may be separated as follows (Frost and Pechuman 1958):

a. First antennal segment distinctly swollen, without dorsal notch; pale rings of tibiae narrow; pale apical wing band reaches posterior margin of wing; length 7 to $8 \mathrm{~mm}$

.....rara (Johnson)

b. First antennal segment barely swollen, with a strong basal notch near apex; pale rings of tibiae broad; pale apical wing band not reaching posterior margin of wing; length $9 \mathrm{~mm}$ 


\section{KEY TO SPECIES OF WEST VIRGINIA ATYLOTUS}

Tribe Tabanini

Genus ATYLOTUS Osten Sacken

The following key is a modification of that of Pechuman (1972) with additions from Stone (1938). Illustrations are made from specimens in possession of the authors.

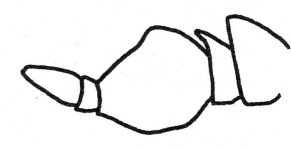

1. a. Pleural hairs bright yellow; basal portion of third antennal segment about as broad as long

b. Pleura gray; basal portion of third antennal segment variable, slender to broad

$\ldots .2$

2. a. Hair of abdomen whitish (some males have median patches of

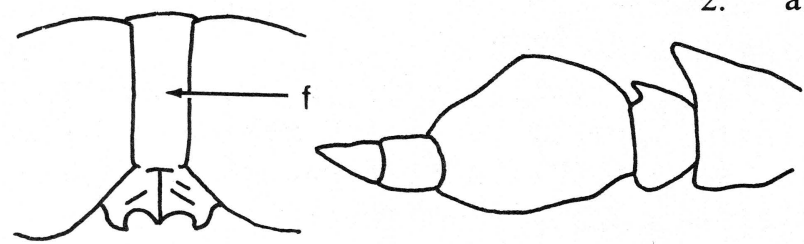
black hair); if yellow hairs are present laterally, more than half of hind femur is black; frons(f) of female moderate in width; eye of both sexes in life usually with a diagonal band; basal portion of third antennal segment stout, with dorsal angle prominent and near middle of length

.....ohioensis (Hine)

b. Hair of abdomen yellow; femora variable, completely yellow to half black; frons of female rather narrow; eye with or without band in life; basal portion of third antennal segment moderately elongate, the dorsal angle straight and basad of middle
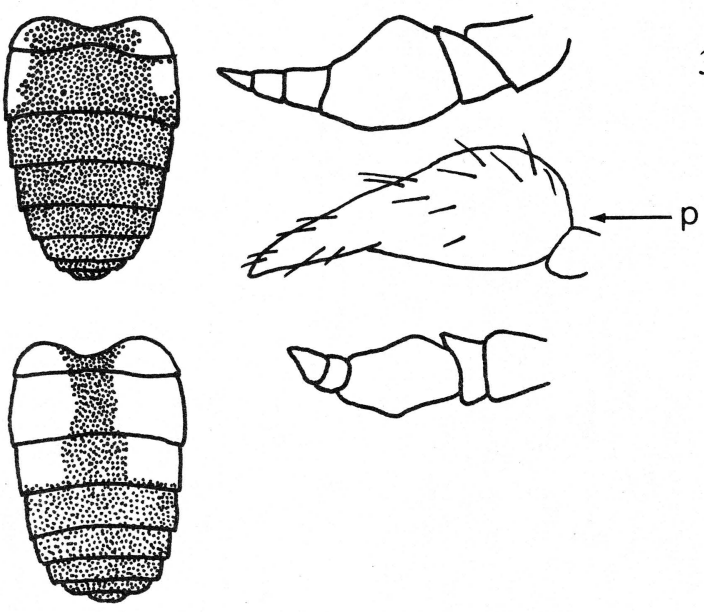

3. a. Abundant black hair on palpi (p) and prescutal lobe; abdomen in female dark brown, narrowly yellowish on sides of first two segments; hair of venter often white on first two segments; genae yellowish at least on upper portions; eye often with band in life; usually over $10 \mathrm{~mm}$ in length

.....pemeticus (Johnson)

b. Only scattered black hairs on palpi and prescutal lobe; abdomen in female usually fuscous in center, broadly yellowish on sides; hair of venter mostly yellow; genae usually gray with gray hairs; no eye band in life; usually under $10 \mathrm{~mm}$ in length

.....thoracicus (Hine)

Atylotus bicolor (Wiedemann)

Seasonal Range-8-VI to 7-VII (10-X).

Distribution-BERKELEY, Sleepy Creek Publ. Hunt. and Fish. Area, 8-VI-77, LLP, LLP. MONONGALIA, WVU Animal Husbandry Farm, 7VII-75, BD, WVU.

This northern species has been reported as far south as DC, PA, NC, and VA but has rarely been found to be numerous. West Virginia records further delimit its southern range. Additional collecting in low lying, marshy areas may result in more instate records.

Atylotus ohioensis (Hine)

Seasonal Range-10-VI to 24-VII.

Distribution-HARDY, Warden Lake, 24-VII-76, BD, WVU. MONONGALIA, Joe's Run, 10-VI-76,
BD, WVU. WETZEL, Lewis Wetzel Publ. Hunt. Area, 18-VI-76, BD, WVU.

Philip (1947 and 1965) describes the southern range of this species from $\mathrm{OH}$ and PA. It is not reported from the other states around West Virginia, indicating that these new records redefine the southern range limit. It is not common anywhere in this area.

Atylotus pemeticus (Johnson)

Seasonal Range-10-VI (1-VI to 24-VII).

Distribution-PRESTON, Cranesville Swamp, 10VI-77, BD, WVU.

The specimen collected in Cranesville Swamp was identified by Pechuman as a form of Atylotus near pemeticus. Teskey (1969) reared two larval types, producing adult specimens that both keyed to $A$. 
pemeticus. Adults of one group of larvae were found by Pechuman to be closer to the holotype of pemeticus than the other, and Teskey refers to this group as "Atylotus species A." Although distinguishing morphological differences have not been found to separate these adults forms, $A$. pemeticus is presently being considered to represent a complex of more than one species. Forms similar to the Cranesville Swamp specimen have been found from SUMMIT, $\mathrm{OH}$, and MONROE, PA, NY, and New England. Specimens are usually collected by sweeping vegetation in sphagnum bogs and swampy areas.

Atylotus thoracicus (Hine)

This is a widespread species reported from the northeastern states south to DE. Pechuman also has confirmed records from PA, OH, and KY. This fly is an inhabitant of open sphagnum bogs and should be found in West Virginia.

Genus HAMATABANUS

Hamatabanus carolinensis (Macquart)

This is a southern species which occurs as far north as MD. Also known from VA, $\mathrm{KY}$, and $\mathrm{OH}$, it should occur in West Virginia.

\section{Genus HYBOMITRA}

Philip (1941) discussed the separation of Hybomitra from Tabanus using characters of hairy eyes and ocelligerous tubercles, and the treatment of those species which possess only one of these characters. Thompson (1967a,b) and Pechuman $(1972,1973)$ have utilized this genus in their respective statewide surveys based on the catalog of Philip (1947).

Hybomitra is generally a northern genus, although a few species are found south to FL. In West Virginia, few of the species are numerous and most of them, like most species of Tabanus, do not readily attack man; $H$. difficilis occurring in wooded areas, is an exception.

The keys which follow were modified from those of Pechuman (1972). A separate key is used for males due to their contiguous, generally hairier eyes and the subsequent lack of median cephalic characteristics. Females of $H$. cincta and $H$. difficilis have practically bare eyes. All species have an ocellar tubercle.

\section{KEY TO SPECIES OF WEST VIRGINIA HYBOMITRA}

\section{FEMALES}

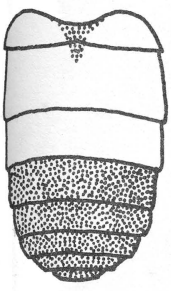

1. a. Black species with first 3 abdominal segments mostly bright orange

.....cincta (Fabricius)

b. Abdomen not so marked

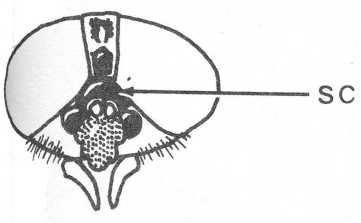

2. a. Subcallus (sc) denuded and shining

b. Subcallus pollinose

....5 5
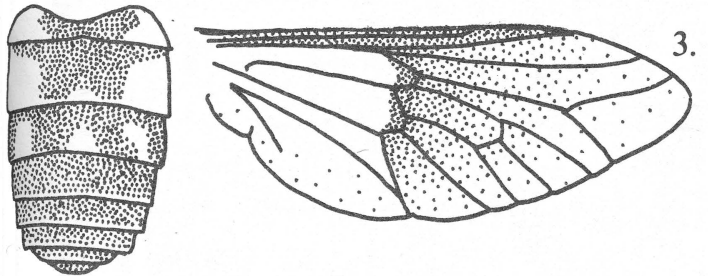

3.

a. Sub small species with dark wing pattern .....hinei (Johnson)

b. Subcallus normal; face below eyes not shining $\ldots .4$
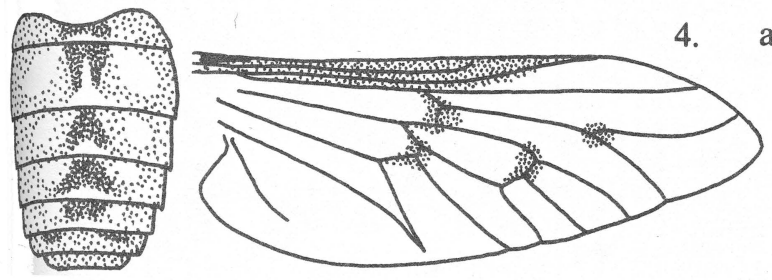

a. Abdomen broadly orange-brown laterally, the median black area usually constricted; eyes hairy; all cross veins strongly spotted with brown lasiophthalma (Macquart) 


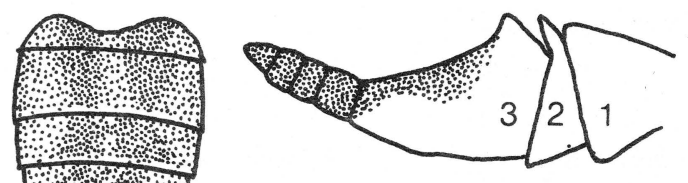

b. Abdomen not broadly orange-brown laterally; eyes apparer bare; basal portion of third antennal segment narrow; cross ve not spotted

difficilis (Wiedema

5. a. Abdomen broadly orange-brown laterally. Median black a usually constricted on third segment

b. Abdomen not as above; if paler laterally, median dark area third segment broad and not constricted
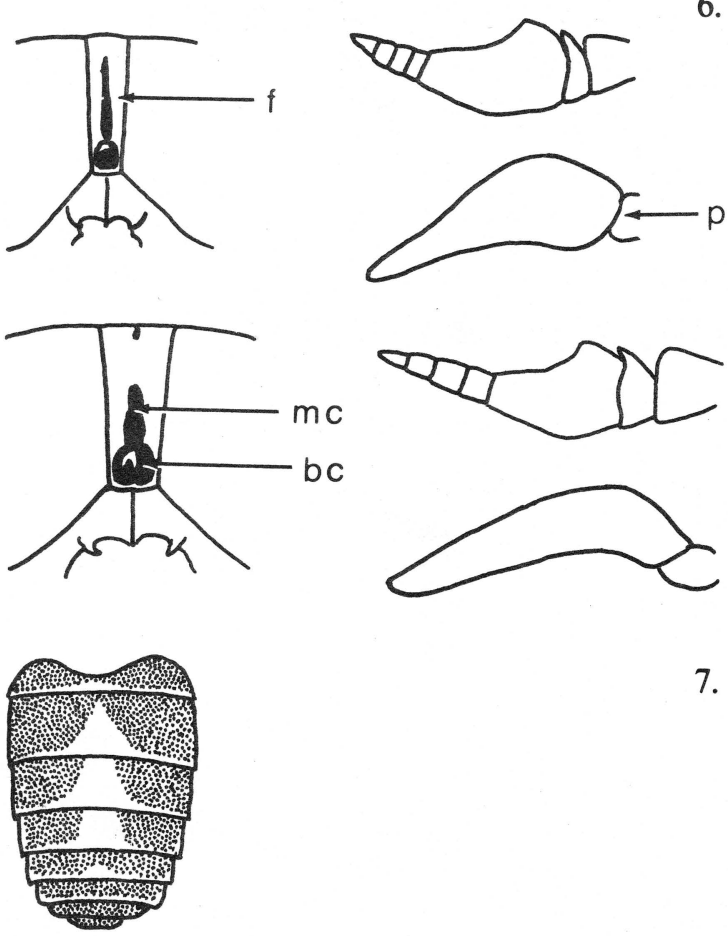

7. a. Abdomen black with a median row of distinct white triang and no sublateral spots

\section{b. Abdomen otherwise marked}

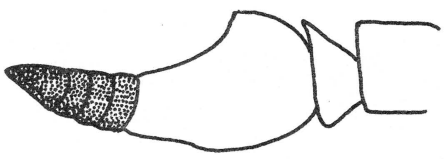

a
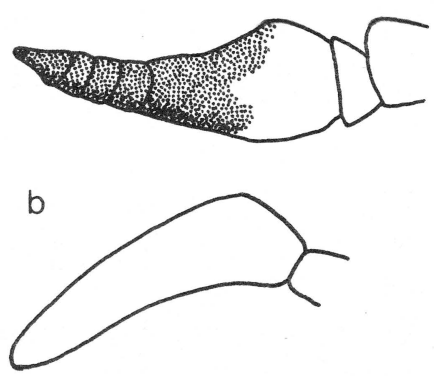

9. a. Second palpal segment slender, scarcely thickened at base

8. a. Third antennal segment sharply bicolored, basal portion entir orange, annuli black; wing heavily and rather uniforn darkened

....trispila (Wiedemar

b. Basal portion of third antennal segment partially bla infuscation of wing not uniform and not very dark

..... sodalis (Willistı

Second palpal segment slender; frons not more than $31 / 3 \mathrm{t}$
times as long as greatest width; basal callus (bc) rounded ab and often joined to median callus (mc); basal portion of th antennal segment rather slender and not deeply excised; $h$ ..... aurilimba (Sto about 5 times as high as width at base, widened above; ba al segment mostly orange and about tv tibial fringe usually black but sometimes extensively yellow 

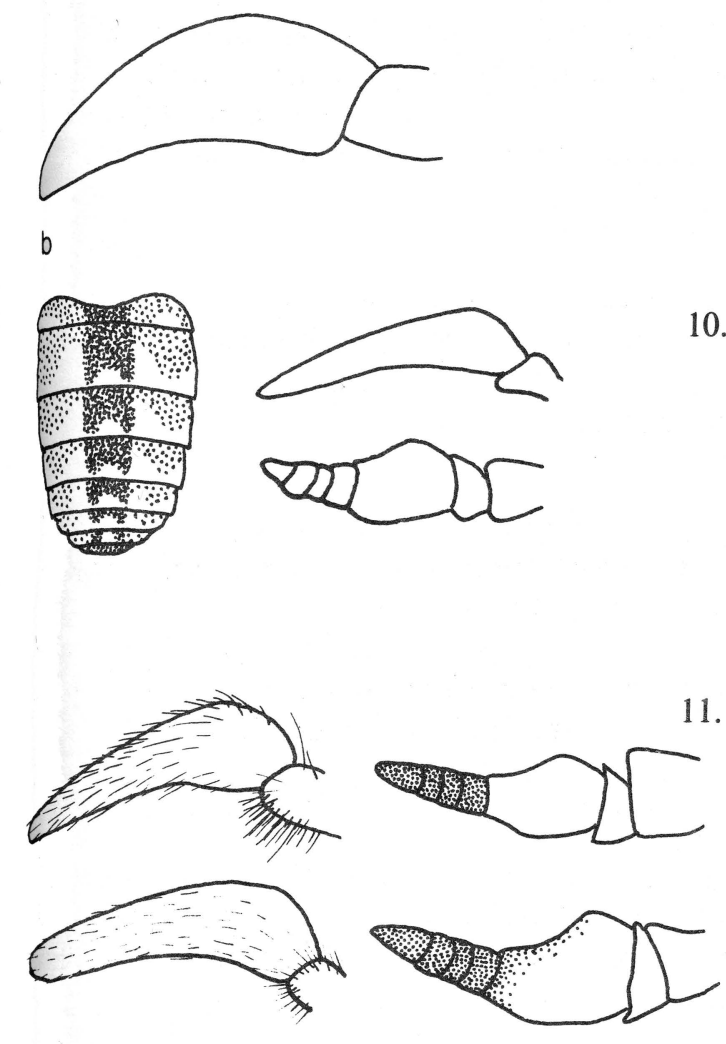

b. Second palpal segment stout, especially so at base

10. a. Femora, except base of hind femora, brown; sides of abdomen reddish brown; second palpal segment extremely slender; third antennal segment practically without dorsal excision

.....miniscula (Hine)

b. Femora usually black; if brown, sides of abdomen not with considerable orange brown

11. a. Hair of palpi long and uneven, semi-erect; base of third antennal segment narrow; hind femora black on basal half, remainder brown

....frosti Pechuman

b. Hair of palpi short and lying smoothly against segment; base of third antennal segment not very narrow; hind femora brownish to completely black

pechumani Teskey and Thomas

12.(9) a. Bifurcation (b) of third longitudinal vein with a distinct spot; third antennal segment stout

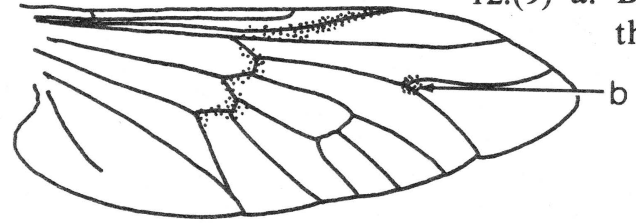

....illota (Osten Sacken)

b. Bifurcation without a distinct spot, third antennal segment slender; legs nearly uniformly brownish, rarely femora somewhat darker; prescutal lobe black

....microcephala (Osten Sacken)

\section{MALES}

1. a. Stiff hairs along midline between eyes

b. No stiff hairs along midline between eyes

.....difficilis (Wiedemann) $\ldots .2$

2. a. Black species with first abdominal segments mostly bright orange

b. Abdomen not so marked .....cincta (Fabricius) $\ldots .3$

3. a. Small dark species with gray, protuberant frontal triangle; genae black, somewhat shining; dark cloud on wing near stigma .....hinei (Johnson)

b. Differing in one or more characters from above $\ldots .4$ 
4. a. Cross veins and bifurcation of third longitudinal vein with distinct dark spots; abdomen broadly orange laterally

..... lasiophthalma (Macquart)

b. Wings entirely hyaline, tinted or with dark spot only on bifurcation

5. a. Abdomen black, obscurely reddish laterally but no distinct sublateral spots, a conspicuous row of white median triangles

b. Abdomen not so marked $\ldots .6$

6. a. Third antennal segment sharply bicolored, basal portion orange, annuli black; line of demarcation between large upper eye facets and smaller lower facets fairly distinct

.....trispila (Wiedemann)

b. Basal portion of third antennal segment partly darkened; upper eye facets only slightly enlarged and gradually merging with smaller lower facets

..... sodalis (Willston)

7. a. Small species, not over $12 \mathrm{~mm}$, with very slender palpal segment; sides of abdomen broadly dark orange but first segment usually completely black; third antennal segment with very shallow dorsal excision

.....miniscula (Hine)

b. Species over $12 \mathrm{~mm}$, but if smaller, second palpal segment stout and dorsal excision distinct

8. a. Prescutal lobe black; femora brown; second palpal segment stout

b. Prescutal lobe reddish at least on disc .... microcephala (Osten Sacken)

9. a. Abdomen broadly orange brown laterally, median black area constricted on third segment and not divided by a pale, longitudinal line; first sternite orange, occasionally with small dark area in center

..... 10

b. Abdomen not broadly orange laterally; orange sublateral spots may be present but black area on third segment is not constricted .....11

10. a. Third antennal segment including annuli reddish; second palpal segment very stout, only slightly longer than thick .....epistates (Osten Sacken)

b. Third antennal segment with at least annuli black; second palpal segment yellow, about twice as long as thick; base of third antennal segment slender and shallowly incised; usually $16 \mathrm{~mm}$ or more; median black area of abdomen usually much reduced ..... aurilimba (Stone)

11. a. Bifurcation of third longitudinal vein with distinct dark spot; palpi very stout; hind tibia dark reddish brown to black; abdomen narrowly yellowish laterally; costal cell and basal portion of wing lightly infuscated; outer claw of fore tarsi about $1 / 3$ longer than inner claw 
12. a. Head relatively small, eye facets scarcely differentiated; second palpal segment brown, paler at apex, somewhat clavate; hind femora brown, basal halves darkened

....frosti Pechuman

b. Head relatively large, eye facets rather distinctly differentiated; second palpal segment yellow to brown rather cylindrical; hind femora variable, often completely black

.....pechumani Teskey and Thomas

Hybomitra aurilimba (Stone)

Seasonal Range-3-VII (VII to early VIII).

Distribution-TUCKER, Dolly Sods, 3-VII-75, LB and DB, WVU (one male and one female).

The female of this species was captured by sweeping cattle while approaching them closely in a truck; the cattle were less disturbed when approached in this manner. The male specimen was swept in late afternoon from its hovering position along a cliff about 2-4 ft. above an outcropping. Another male was spotted nearby but was not taken. These observations agree with those of Blickle (1955) for hovering males. Hybomitra cincta (Fabricius)

Seasonal Range-1-VII (22-VI to 14-VIII).

Distribution-MONONGALIA, Chestnut Ridge, Harris Lake, 1-VII-75, LB and BD, WVU. PRESTON, Brandonville Pike at Muddy Creek, 1-VII-75, LB and BD, WVU.

This attractive tabanid has been reported from all of the contiguous states. Male hovering behavior reported by Pechuman $(1972,1973)$ was confirmed by observation and capture in mid-afternoon of a male hovering in a small sunlit clearing in an area of low bush and scattered trees near a fast-flowing stream. A long series of female $H$. cincta was recently taken by Amrine of WVU. The females were alighting on the heads of persons swimming in a pond at Chestnut Ridge, Monongalia County.

Hybomitra difficilis (Wiedemann)

Seasonal Range-9-V to 29-VII (16-VIII).

Distribution-BARBOUR, Junior, 2-VI-78, LB, WVU. BERKELEY, Sleepy Creek Publ. Hunt. and Fish. Area, 28-V-76, BD, WVU. BRAXTON, Kanawha Run-Sutton Lk., 28-V-78, LB, WVU. BROOKE, Castleman Run Lk., 9-VI-76, BD, WVU. FAYETTE, Rainelle, 12-VI-77, TK, WVU. GILMER, Cedar Ck. St. Pk., 4-VI-77, LB, WVU. GRANT, Greenland, 7-VII-78, CC, WVDA. GREENBRIER, White Sulphur Springs, 9-V-70, AC, WVDA. HAMPSHIRE, Capon Bridge, 24-VI-75, CC, WVDA. HANCOCK, Tomlinson Run St. Pk., 9-VI76, BD, WVU. HARDY, Moorefield, 29-V-76, WN and KE, WVDA. HARRISON, 1-VI-76, CS, WVU. JEFFERSON, Shannondale, 1-VI-77, JH, WVDA. KANAWHA, Kimberly Rd., 17-VI-76, SF, WVDA.
MCDOWELL, Panther St. For., 21-V-77, LB, WVU. MARION, Bunner's Ridge, 22-VI-75, TM, WVU. MASON, McClintic Publ. Hunt. and Fish. Area, 21V-76, BD, WVU. MINERAL, Burlington, Shale Barrens, 24-V-77, LB, WVU. MONONGALIA, Triune, 28-V-76, LB, WVU. MORGAN, Cherry Run, 6-VI-78, CC, WVDA. PLEASANTS, Bens Run, 25V-77, JH, WVDA. POCAHONTAS, Boyer, 9-VI-76, CC, WVDA. PRESTON, Etam, 20-V-76, BD, WVU. RANDOLPH, Stuart Rec. Area, 16-VI-73, FR, CU. RITCHIE, North Bend St. Pk., 23-VI-77, LB, WVU. ROANE, $2 \mathrm{mi}$. W. Spencer, 27-V-78, LB, WVU. SUMMERS, Pipestem St. Pk., 13-V-76, PG, WVDA. TAYLOR, Grafton, 8-VI-52, CVS, CM. TUCKER, Dolly Sods, 29-V-78, JA, WVU. WAYNE, Cabwaylingo St. For., 21-V-77, LB, WVU. WETZEL, Lewis Wetzel Publ. Hunt. Area, 18-VI-76, BD, WVU. WYOMING, Pineville, 20-V-77, LB, WVU.

Most West Virginia records are from late May through early July. This species is especially annoying and, together with $H$. lasiophthalma, presents serious problems to cattle and people during the month of June. This species is abundant and actively attacks man in wooded areas. Even though this is a common species as an adult, larvae have never been observed.

Hybomitra epistates (Osten Sacken)

This is a northern species which is not known south of a line from northern $\mathrm{NJ}$ to central $\mathrm{OH}$. It may occur in northern and mountainous areas in West Virginia.

Hybomitra frosti Pechuman

Of the surrounding states, this species has been found only in central PA. It is a newly described species with obscure habits, but may occur in disjunct colonies in West Virginia sphagnum bogs.

Hybomitra hinei (Johnson)

Records from MD, VA, and PA indicate the probable occurrence of this bog-dwelling species in West Virginia.

Hybomitra illota (Osten Sacken)

This northern species occurs in $\mathrm{OH}, \mathrm{PA}$, and MD, but is generally not common south of NY.

Hybomitra lasiophthalma (Macquart)

Seasonal Range-12-V to 12-VII (12-IV to 27-VII). Distribution-BARBOUR, Pleasant Ck., 12-V-77, LB, WVU. BERKELEY, Sleepy Creek Publ. Hunt. 
and Fish. Area, 28-V-76, BD, WVU. BROOKE, Castleman Run Lk., 9-VI-76, BD, WVU. CALHOUN, Rt. 33, 2 mi. E. County line, 27-V-78, LB, WVU. GILMER, Cedar Ck. St. Pk., 4-VI-77, LB, WVU. GRANT, Greenland, 31-V-78, CC, WVDA. GREENBRIER, Clendinsville, 18-VI-76, JH, WVDA. HAMPSHIRE, Grace, 25-V-76, WN and KE, WVDA. HANCOCK, Tomlinson Run St. Pk., 9VI-76, BD, WVU. HARDY, Moorefield, 12-V-67, WVDA. JACKSON, Ripley, 22-V-75, JH, WVDA. JEFFERSON, Shannondale, 7-VII-78, CC, WVDA. KANAWHA, St. Albans, 5-VI-76, JH, WVDA. MASON, Point Pleasant, 5-VI-75, JH, WVDA. MINERAL, New Creek, 11-VI-76, BD, WVU. MONONGALIA, Morgantown, 15-V-75, BD, WVU. MORGAN, Cherry Run, 31-V-78, CC, WVDA. OHIO, Bear Rocks Lk., 25-V-77, JH, WVDA. PENDLETON, Seneca Campground, 23-VI-76, BD, WVU. PLEASANTS, Ben's Run, 25-V-77, JH, WVDA. POCAHONTAS, Boyer, 9-VI-76, CC, WVDA. PRESTON, Reedsville Exp. Sta., 23-V-77, LB, WVU. RANDOLPH, Rt. 219, 5 mi. N. Elkins, 5VI-76, BD, WVU. RITCHIE, N. Bend St. Pk., 23-VI78, JH, WVDA. ROANE, 2 mi. W. Spencer, 27-V-78, LB, WVU. SUMMERS, Pipestem St. Pk., 13-V-76, PG, WVDA. TUCKER, Blackwater Falls, 12-VII-78, JH, WVDA. WEBSTER, Cranberry Campground, 20-VI-75, BD, WVU. WETZEL, Lewis Wetzel Publ. Hunt. Area, 18-VI-76, BD, WVU. WOOD, V-50, UA.

This attractive tabanid is known from all of the surrounding states, and is the most abundant of the Hybomitra in West Virginia, where it is an important early season pest.

Hybomitra microcephala (Osten Sacken)

Seasonal Range-1-VII to 18-VIII (8-VI).

Distribution-MONONGALIA, 1-VII, LMP, WVU. PRESTON, Cranesville Swamp, 18-VIII-76, LB and BD, WVU. RANDOLPH, Laurel Fk. Campground, 8-VIII-75, BD, WVU.

West Virginia lies along the southern range of $H$. microcephala, which occurs south of the state only in mountainous areas. It is known from the contiguous states of $\mathrm{OH}, \mathrm{PA}$, and VA.

\section{Hybomitra miniscula (Hine)}

Seasonal Range-10-VIII to 18-VIII (10-VII).

Distribution-PRESTON, Cranesville Swamp, 18VIII-76, LB and BD, WVU. TUCKER, Olson Bog, 10VIII-76, BD, WVU (Teneral male).

This slow-flying species is known to exist only in or around sphagnum bogs, an observation confirmed by this study. H. miniscula does not occur south of West Virginia, which contains the southernmost sphagnum bogs. Records are also known from $\mathrm{OH}$ and PA.

This small Hybomitra is characteristic in its habits. While collecting at Cranesville Swamp, the authors observed its slow flight, rarely more than $2 / 3$ meter above the ground. It was readily caught with a sweep net and responded well to the $\mathrm{CO}_{2}$ baited modified malaise traps with targets. Females followed the collectors and attempted to land on their wet, dark green hip boots. Several hovering males were also taken during the middle of the day.

Hybomitra sodalis (Williston)

Seasonal Range-27-VI to 6-VIII (25-VI).

Distribution-GRANT, Greenland, 13-VII-78, CC, WVDA. HAMPSHIRE, Grace, 7-VII-77, CC, WVDA. HARDY, Warden Lk., 24-VII-76, BD, WVU. PENDLETON, Spruce Knob, 5-VIII-60, HM and GW, CM. POCAHONTAS, Cranberry Glades, 16-VII-55, CWS, USNM. RANDOLPH (?), near Cheat Mt., 6-VIII-60, HM and GW, CM. SUMMERS, Pipestem St. Pk., 28-VII-76, TM, WVU. UPSHUR, Stonecoal Lk., 27-VI-77, PV, WVDA. WEBSTER, Cranberry Campground, 11-VII-76, BD, WVU. WETZEL, New Martinsville, 6-VII-76, TM, WVU.

$H$. sodalis was recently separated from $H$. trispila by Pechuman (1960), and earlier records are in need of revision. To date $H$. sodalis is known from PA, MD, $\mathrm{KY}, \mathrm{VA}$, and $\mathrm{NJ}$, and has been taken in all but the central and southwestern geographical zones in West Virginia. It is more commonly encountered in mountainous areas.

Hybomitra trispila (Wiedemann)

Although $H$. trispila and $H$. sodalis have been found to fly together, $\boldsymbol{H}$. trispila is on the wing earlier and is often found at lower elevations than $H$. sodalis. It is known from all of the contiguous states except $\mathrm{OH}$ and will probably be found in West Virginia.

Hybomitra pechumani Teskey and Thomas

Seasonal Range-10-VI to 26-VII.

Distribution-MINERAL, New Creek, 25-VI-76, BD, WVU. MONONGALIA, 27-VI, WVU (male). PRESTON, Terra Alta, 29-VI-18, SR, USNM (male dark form). RANDOLPH, Roaring Plains, 26-VII-76, LB and BD, WVU. TUCKER, Dolly Sods, 3-VII-75, LB, WVU.

This is a newly described species, the members of which were previously considered to be $H$. typhus (Whitney). All typhus-like forms collected in West Virginia are apparently $H$. pechumani.

Genus TABANUS Linn.

The genera Hybomitra and Tabanus comprise the group generally known as "horse flies." Most of these species are not known to attack man. Thompson (1967a, b, 1969) in surveying for tabanids of MD was bitten by $T$. lineola, marginalis, pumilus, and quinquevittatus. Pechuman $(1972,1973)$ also reports being attacked by $T$. sparus milleri. Drees on more than one occasion has been attacked by T. pumilus and sparus milleri and has observed T. sulcifrons attacking swimmers emerging from the lake in Cacapon State Park, 2 August 1975. The first author also collected $T$. 
americana in MINGO after it landed on his blue jeans. Larger tabanids are unsuccessful feeders on humans due to their noisy approach. This genus is very important with regard to wild and domestic animals, although it is impossible to accurately place economic values on the damage done.

Taxonomic Discussion and Use of Keys. The following ieys largely follow those of Pechuman (1972, 1973), lthough a few couplets were incorporated from Stone 1938). Separate keys are given for females and males recause of the lack of median cephalic characteristics due to contiguous eyes in the latter. Males of T. longus are not yet known. Most of the structural characters for the separation of Tabanus species are confined to the head and its appendages. Eye color is used only for the separation of Tabanus pumilus, T. sparus, and T. sparus milleri, although it has been utilized in the past for other species. Female Tabanus are often identified by their characteristic frons structures, the median and basal callus. In the male, the frontal triangle lies directly below the contiguous eyes and above the antennae.

\section{KEY TO SPECIES OF WEST VIRGINIA TABANUS}

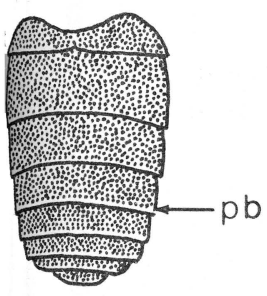

\section{FEMALES}

1. a. Abdomen unicolorous or with narrow indistinct posterior bands (pb)

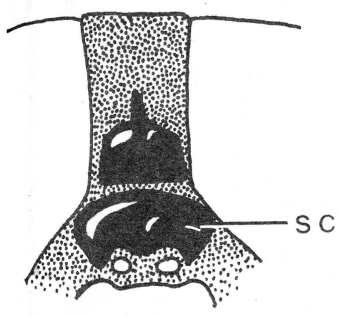

b. Abdomen with one or more median triangles or median stripe .... 10

2. a. Subcallus (sc) denuded; mesoscutum entirely black; wing uniformly dark brown to black

\section{atratus atratus Fabricius}

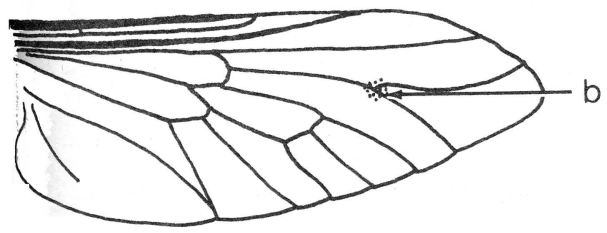

b. Subcallus not denuded

3. a. Bifurcation (b) with a distinct spot or entire wing dark

b. Bifurcation without a distinct spot, wing essentially hyaline ....9 9

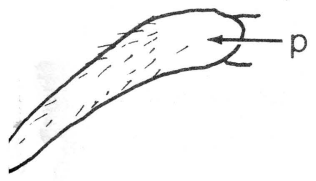

4. a. Palpi dark brown to black

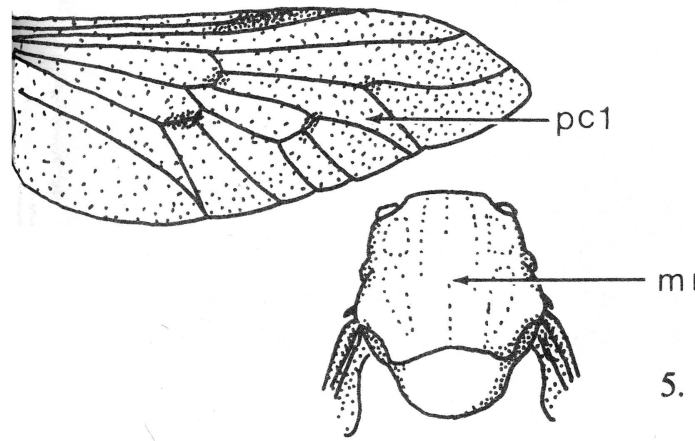

b. Palpi (p) pale to reddish brown; all femora black; first posterior cell $(\mathrm{pc} 1)$ narrowed at wing margin; thorax with a lavender cast .....gladiator Stone

5. a. Mesonotum $(\mathrm{mn})$ white pollinose 


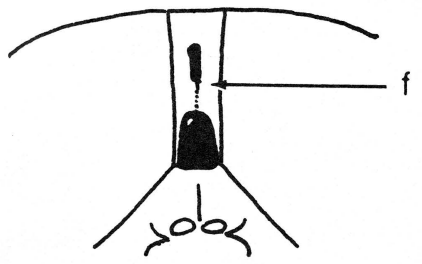

6. a. Frons (f) orange-brown, moderate in width; wing veins not margined with brown although darker clouds may be present ..... stygius Say
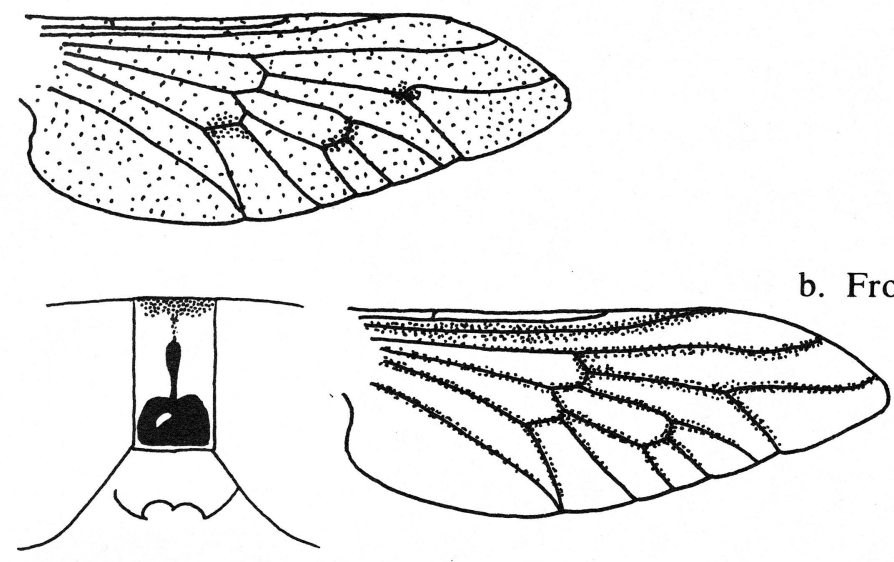

b. Frons gray, broad; wing veins margined with brown

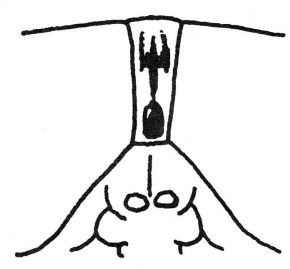

7. a. Frons narrow, widened above; antennae mostly orange, including first two segments

.....subniger Coquillett
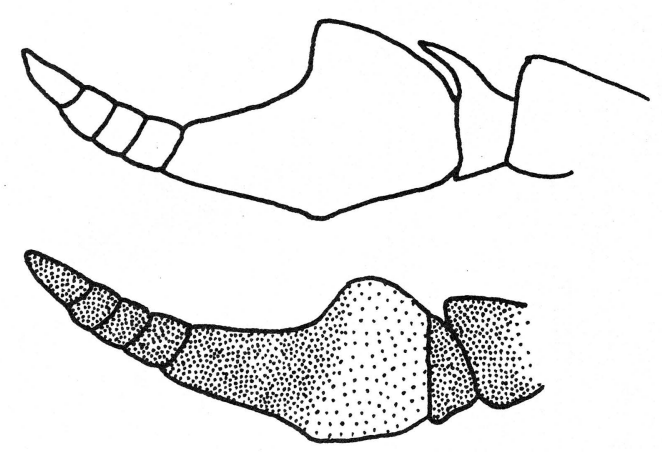

b. Frons wider, parallel sided; first two antennal segments black and third often partly black

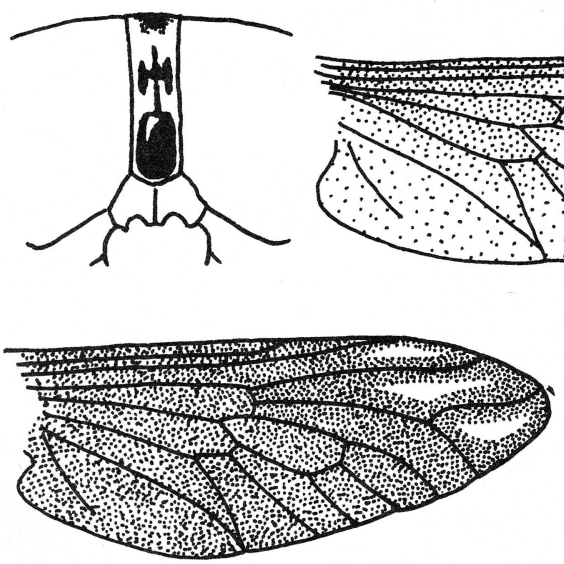

8. a. Wings mostly hyaline, with dark spots; abdomen without bloom .....nigrescens Palisot de Beuvois

b. Wings rather uniformly dark or with veins broadly outlined with dark infuscation; abdomen brownish black with bluish-white bloom 


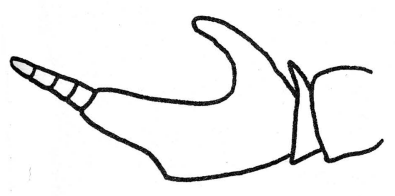

9.(3) a. Wing hyaline with a dark brown costal cell (cc); abdomen usually with narrow gray posterior borders

.....americanus Forster

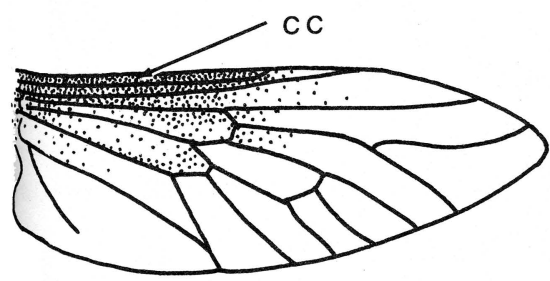

b. Wing uniformly dilutely infuscated; costal cell yellow; abdomen sometimes with traces of small median triangles

.....calens Linnaeus
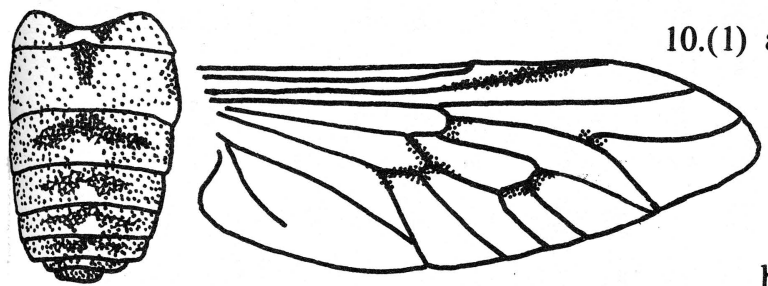

10.(1) a. Abdomen orange brown with median dark area; wings spotted; femora black

abdominalis Fabricius

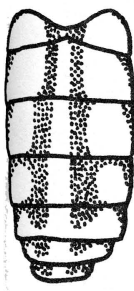

11. a. Abdomen with a longitudinal median stripe which may or may not be widened at posterior margins of segments; abdomen with sublateral stripes or spots; if under $15 \mathrm{~mm}$, dark brown with median triangles arising from pale bands, front tibiae unicolorous and subcallus shining; (see couplet 43a)

b. Abdomen with median markings not forming an uninterrupted stripe; abdomen with or without sublateral stripes or spots

....26 26

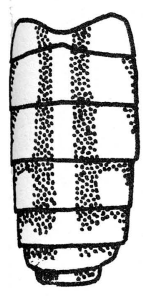

12. a. Spots forming median abdominal stripe nearly parallel sided; lateral markings usually form a shorter stripe on each side of median stripe and parallel to it but this stripe may be broken into separate spots or obsolete
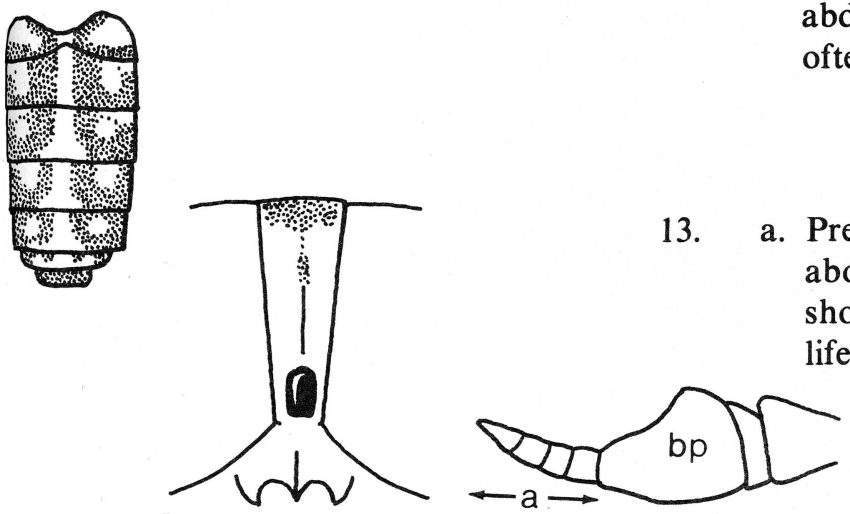

b. Spots forming median stripe widened at posterior margin of abdominal segments; lateral markings broken into separate, often roundish spots

13. a. Prescutal lobe usually paler than mesonotum; frons widened above; annulate (a) portion of third antennal segment usually shorter than basal plate (bp); costal cell usually hyaline; eye in life with 2 purple bands 

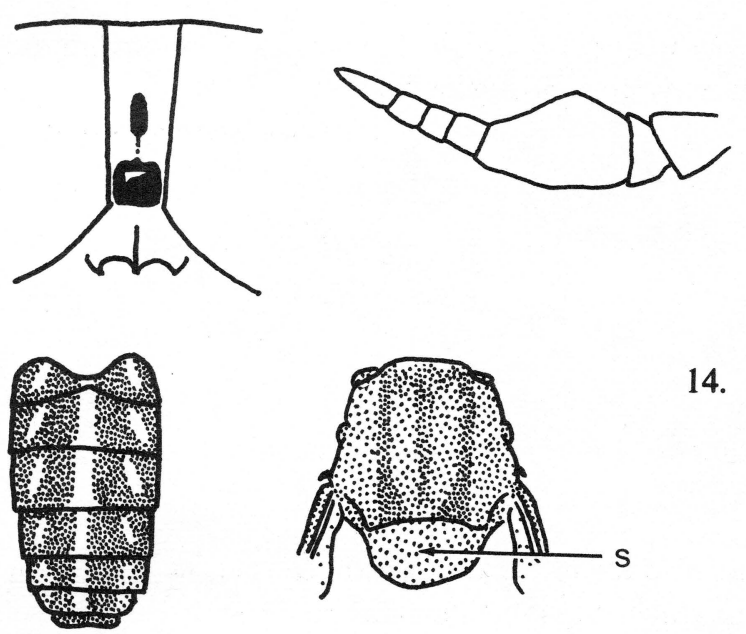

14. a. Scutellum (s) and thorax concolorous

.... lineola Fabricius

b. Prescutal lobe concolorous with rest of mesonotum; frons nearly parallel sided; annulate portion of antennal segment usually longer than basal plate; costal cell infuscated; eye in life with a single purple band

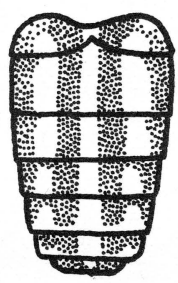

b. Scutellum reddish, sometimes faintly on posterior margin

15. a. Legs predominantly reddish; sublateral abdominal stripes essentially parallel sided similis Macquart
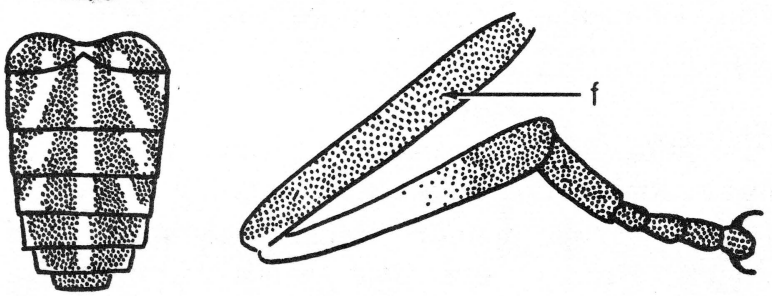

b. Femora (f) of at least fore and hind legs darkened; sublateral abdominal stripes offset between second and third segments ..... subsimilis subsimilis Bellardi
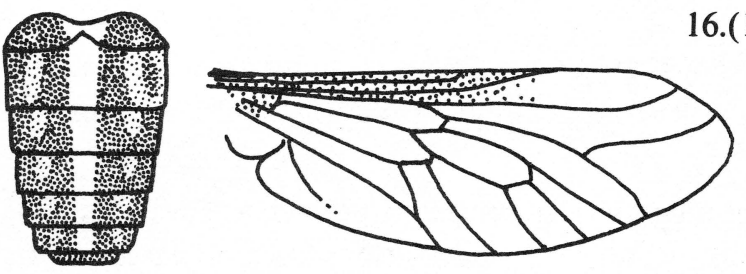

16.(13)a. Palpi, pleurae and costal cell yellow

....quinquevittatus Wiedemann

b. Palpi white; pleurae gray, sometimes with a yellowish tint; costal cell pale yellow to dark brown, brownish or blackish species

17. a. Costal cell dark brown; pleurae very pale, strongly contrasting with dark thoracic dorsum; frons about 4 to $4 \frac{1}{2}$ times as high as width at base

....fuscicostatus Hine

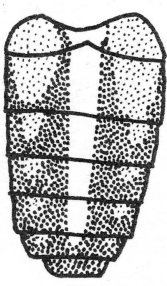

b. Costal cell yellow; pleurae scarcely contrasting with dorsum of thorax; frons $31 / 2$ to 4 times as high as wide 


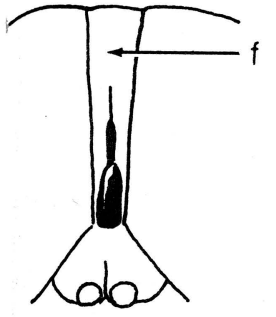

18.(12)a. Dorsum of thorax covered with yellow hairs, without longitudinal stripes; abdominal stripes yellow; frons (f) very narrow; antennal plate broad; costal cell colored

b. Without this combination of characters
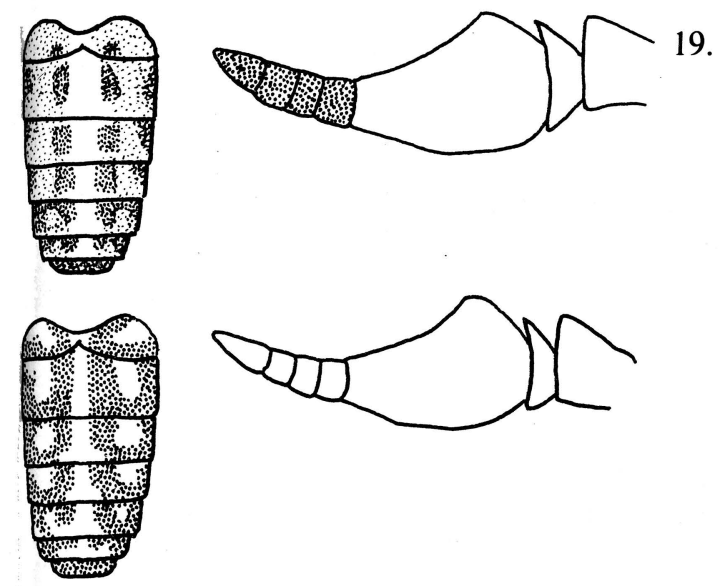

19. a. Annulate portion of third antennal segment black; femora dark; palpi yellow; face and pleurae yellow-haired

....fulvulus Wiedemann

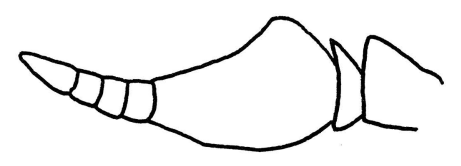

b. Third antennal segment usually entirely orange yellow; femora pale sometimes darkened at base; palpi white; face and pleurae pale-haired

pallidescens Wiedemann

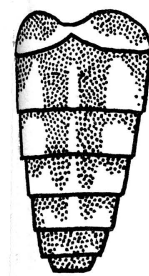

20. a. All wing veins margined with brown

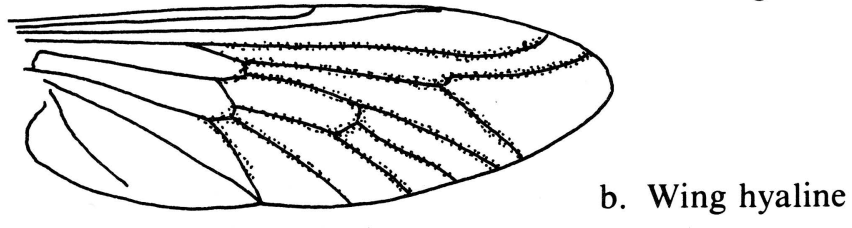

gracilis Wiedemann
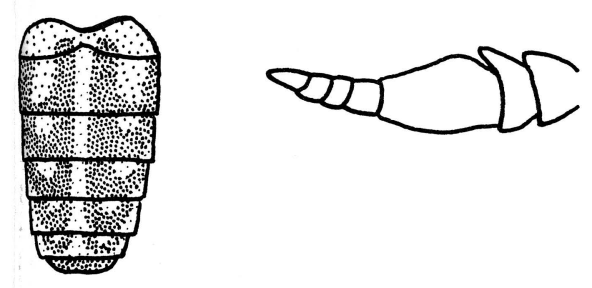

21. a. Third antennal segment uniformly yellow brown ..... zythicolor Philip
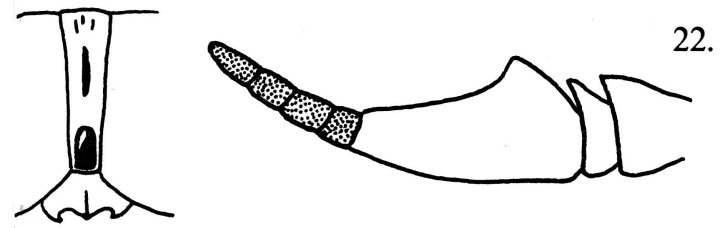

b. Annulate portion of third antennal segment black

22. a. Frons narrow, widened above

..... sackeni Fairchild

b. Frons broader, parallel sided
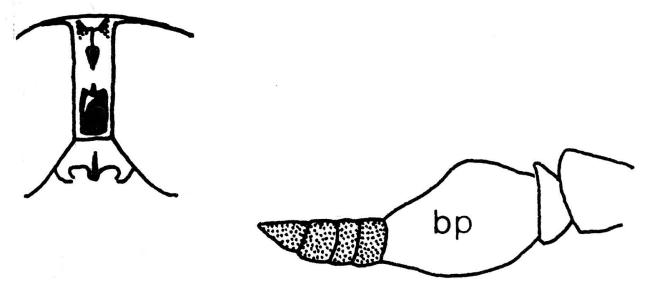

23. a. Basal plate (bp) of antennae about as wide as long; costal cell heavily infuscated 
b. Basal plate longer than wide; costal cell hyaline or lightly infuscated
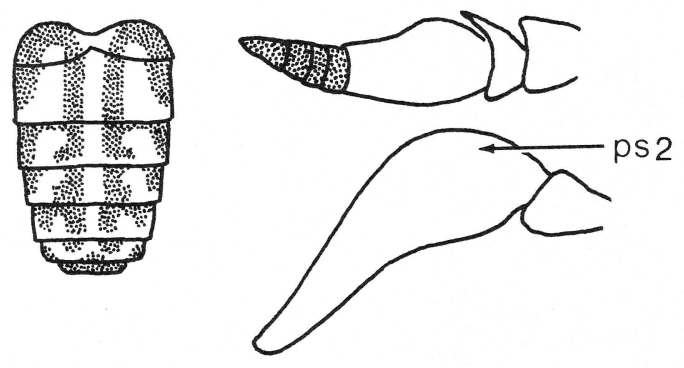

24. a. Second palpal segment (ps2) markedly swollen basally; median abdominal stripe broad

..... sagax Osten Sacken

b. Second palpal segment not markedly swollen basally; median abdominal stripe narrow

.... 25

25. a. Pale markings of abdomen yellowish brown, the sublateral spots touching the hind margins of the segments .....sublongus Stone

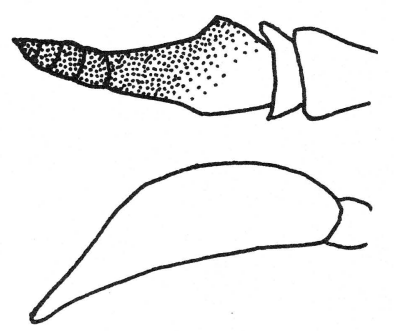

b. Pale markings grayish, the sublateral spots small and separated from the hind margins ..... longus Osten Sacken

26.(11)a. No pale median spot on second abdominal segment but occasionally 2 small sublateral spots; fore tibiae distinctly bicolored; thorax white pollinose .....trimaculatus Palisot de Beauvois

b. Second abdominal segment with a pale median spot $\ldots .27$

27. a. Abdomen with both median and sublateral spots

b. Abdomen without sublateral spots although abdomen may be paler laterally

28. a. Bifurcation with a dark spot (see illustration for couplet 3)

b. Bifurcation without a dark spot

29. a. Wing with large brown maculations not confined to cross veins and bifurcation; lateral abdominal spots confined to posterior margins and often joined to median triangles

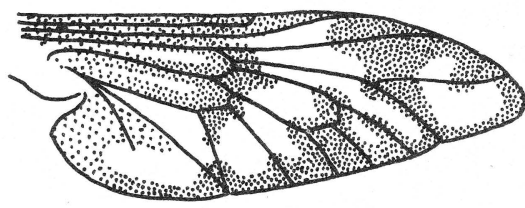




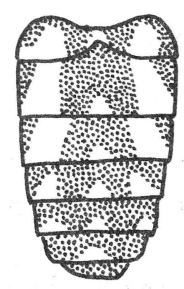

a

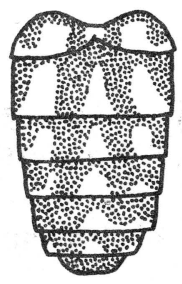

b
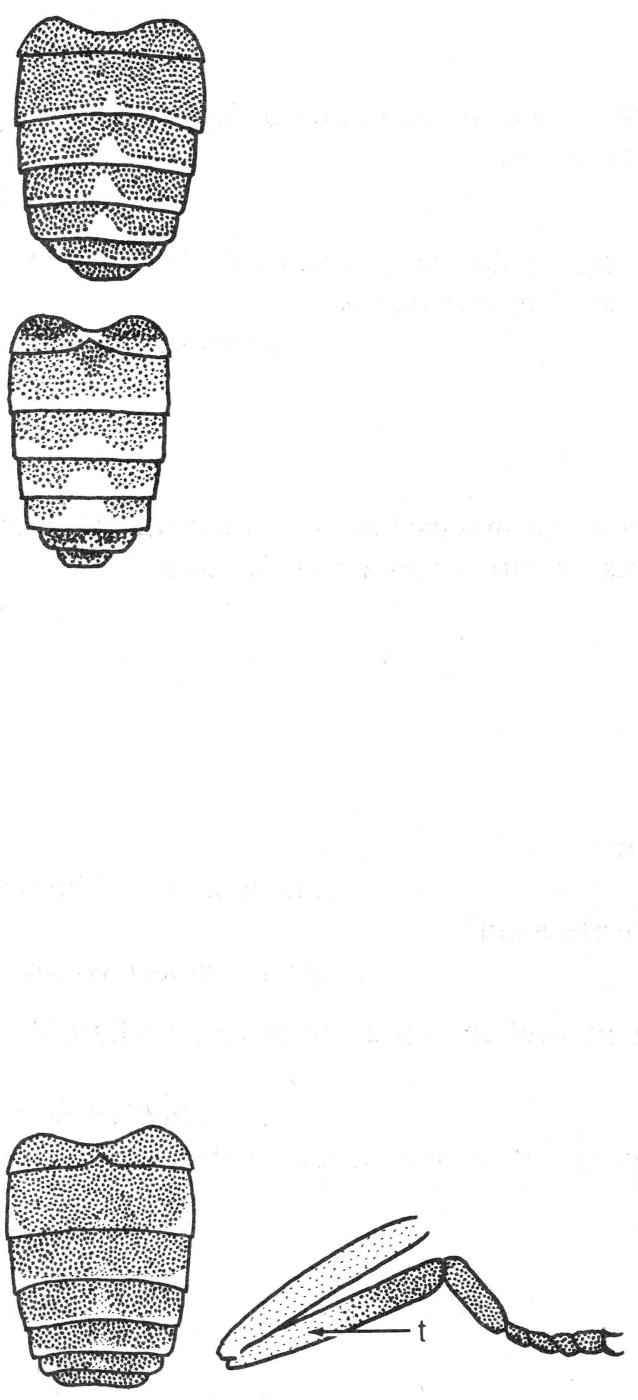

35. a. Sublateral white abdominal spots considerably larger than the small median triangles and usually reaching anterior border of second and third segments

marginalis Fabricius

b. Median triangles are relatively larger and sublateral spots smaller, rarely extending to anterior border of segments ..... vivax Osten Sacken

36.(27)a. Pale spot on second abdominal segment distinctly smaller than spots on third and fourth segments; scutellum with pale pile; fore tibia unicolorous

b. Pale spot on second segment not markedly smaller than those on two following segments

37. a. Abdomen black with very small median triangles ..... superjumentarius Whitney

b. Abdomen usually brownish, at least in part; median triangles large; middle and hind tibiae uniformly reddish brown; first and second longitudinal veins not margined with brown

38. a. Genae, pleurae and venter pale haired

b. Genae, pleurae and venter brown haired .....molestus molestus Say .....molestus mixus Philip

39.(36)a. No spot at bifurcation

b. Bifurcation with a conspicuous brown spot (see illustration for couplet 3)

40. a. Wings with a smokey tinge; costal cell heavily colored; large species with median abdominal triangles small or obsolete

....41

b. Wings hyaline; costal cell hyaline or slightly tinted, smaller species with conspicuous median triangles

41. a. Fore tibia (t) bicolored 
42. a. Third antennal segment reddish yellow; median abdominal triangles faint and arising from faint posterior bands; first posterior cell narrowed toward margin (see illustration for couplet $9 b$ )

.....calens Linnaeus

b. Third antennal segment partly black; median triangles small but distinct and not arising from bands; first posterior cell not narrowed

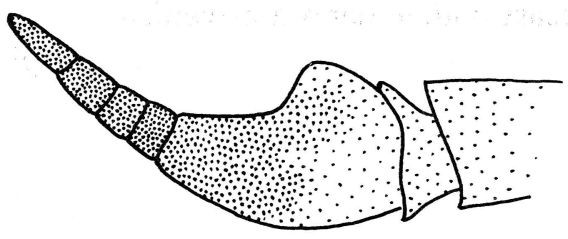

.....catenatus Walker

b
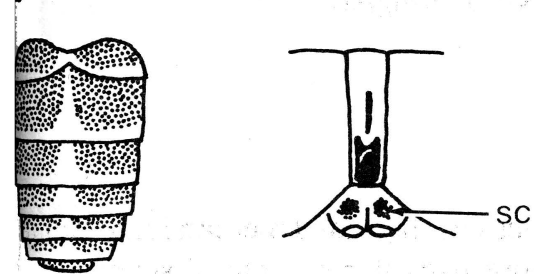

43.(40)a. Tibiae unicolorous although fore tibiae may be slightly paler at base; first posterior cell slightly or not at all narrowed at margin; subcallus (sc) thinly pollinose or dunuded; usually under $15 \mathrm{~mm}$ .....nigripes Wiedemann

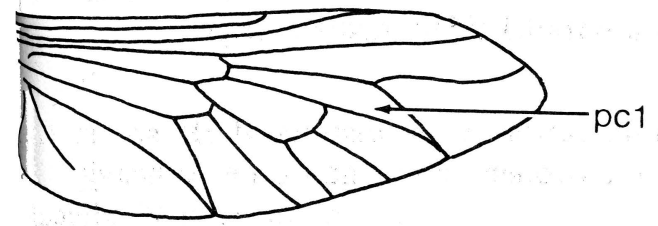

b. At least fore tibiae bicolored; first posterior cell (pc1) much narrowed and may be closed or petiolate; subcallus pollinose; usually over $15 \mathrm{~mm}$
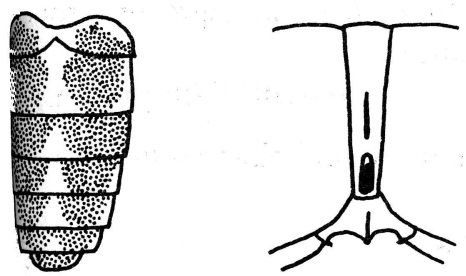

44.

a. Frons over 6 times as high as width at base; hind tibiae uniformly yellowish-white, barely darkened at apex; median triangle on second abdominal segment usually crossing segment and joining spot on first segment; first posterior cell usually closed, frequently petiolate

.....petiolatus Hine
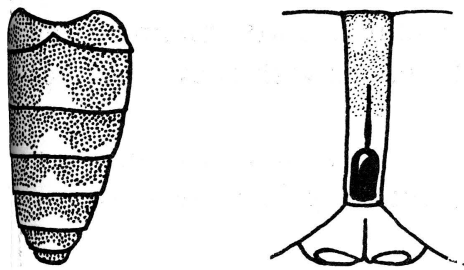

b. Frons less than 6 times as high as wide; hind tibiae often extensively dark toward apex; median triangle rarely crossing second abdominal segment; first posterior cell rarely petiolate .....melanocerus Wiedemann

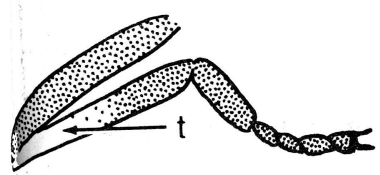

45.(39)a. Fore tibia (f) bicolored, basal portion pale

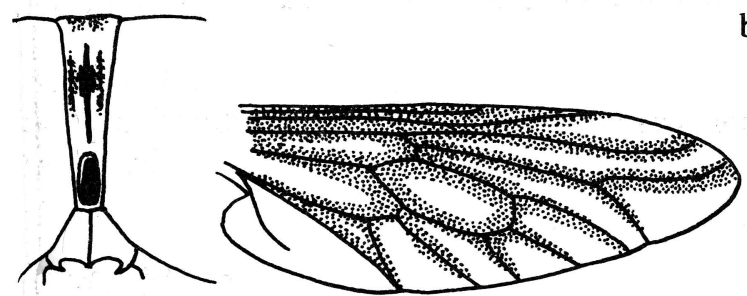

b. Fore tibia unicolorous or occasionally base somewhat brownish with orange hair; frons narrow, not less than 6 times as high as width at base and widened above; dark species with obvious middorsal abdominal triangles. Wing rather heavily infuscated along longitudinal veins; pleurae paler than dorsum of thorax which is obviously striped; basal plate narrow 


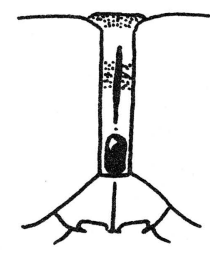

46. a. Frons narrow, at least 5 times as high as wide; first posterior cell normally closed; all femora black (see illustration for couplet 10a)

abdominalis Fabricius

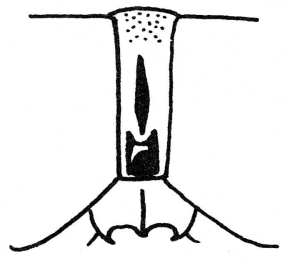

b. Frons moderately wide, about 4 times as high as wide; first posterior cell normally open although often much narrowed at margin; at least middle femora brownish

..... sulcifrons Macquart

II. MALES (No T. longus)

1. a. Eyes hairy

b. Eyes bare

2. a. Abdomen with a conspicuous parallel sided median longitudinal white stripe and similar more irregular sublateral stripes ..... subsimilis subsimilis Bellardi

b. Abdomen without a parallel sided median stripe

3. a. Crossveins and bifurcation with distinct dark spots; first antennal segment not swollen above; hair on eyes heavy .....reinwardtii Wiedemann

b. Wing without distinct spots; first antennal segment strongly swollen above; hair on eyes sparse

$$
\text { .....fairchildi (in part) Stone }
$$

4. a. Abdomen unicolorous or with narrow indistinct pollinose bands

b. Abdomen with median markings

5. a. Frontal triangle denuded and shining; third antennal segment with a rather long tooth; black species with heavily infuscated black wings

.....atratus atratus Fabricius

b. Frontal triangle pollinose and differing in at least one other character from the above

6. a. Bifurcation without a distinct spot

b. Bifurcation with a distinct spot or wing mostly black .. 7

7. a. Wing dilutely infuscated, costal cell darker; hind tibial fringe black

calens Linnaeus

b. Wing hyaline, costal cell deep yellow; hind tibial fringe orange ..... americanus Forster

8. a. Genae gray 
b. Genae grayish brown to black; blackish-brown to black species

9. a. Wing almost completely black or with broad heavy infuscation along all veins; abdomen with whitish bloom

b. Wing subhyaline .....aranti Hays

10. a. Lower margin of area of large eye facets somewhat sinuate and at lowest point about on level with top of antennal pits

.....subniger Coquillett

b. Lower margin of large eye facets more nearly straight and somewhat higher than antennal pits

11. a. Integument of thoracic dorsum brown, contrasting with black abdomen; wing membrane, except for spots, rather uniformly dilutely infuscated .....stygius Say

b. Integument of thoracic dorsum dark brown to black, usually contrasting only slightly with black abdomen; apex of wing, except for spots, almost hyaline

.....nigrescens Palisot de Beauvois

12. (4)a. Abdomen broadly orange laterally with conspicuous black median spots and no evident pale median markings; large and small eye facets little differentiated; femora black; wings spotted and first posterior cell narrowed or closed at wing margin

b. Abdomen with pale median markings and differing in at least one other character from the above

13. a. Thorax with a lavender tint, narrowly and inconspicuously striped; second palpal segment slender, at least 3 times as long as thick

.....gladiator Stone

b. Thorax brown, broadly and conspicuously striped; second palpal segment about twice as long as thick

.....abdominalis (in part) Fabricius

14. a. All veins outlined by a pale brown infuscation; third antennal segment uniformly brownish; abdomen with a median row of pale triangles which usually do not quite cross segments and with pale sublateral spots; moderate sized species not over $16 \mathrm{~mm}$

b. Without the above characteristics .....gracilis Wiedemann ....15

15. a. Abdomen with a longitudinal stripe which may or may not be somewhat widened at posterior margins of segments

.....16

b. Abdomen with median markings not forming an uninterrupted stripe

16. a. Spots forming median parallel sided abdominal stripe; sublateral spots similar but often more irregular, rarely broken into roundish spots 
b. Median spots widened at posterior margin of each segment so that stripe is not parallel sided, sublateral spots usually roundish

17. a. Prescutal lobe usually paler than mesonotum; annulate portion of third antennal segment usually shorter than basal plate; costal cell usually hyaline

b. Prescutal lobe usually concolorous with mesonotum; annulate portion of third antennal segment as long as or longer than basal plate; costal cell infuscated

18. a. Scutellum and thorax concolorous; hind femora usually dark ..... lineola Fabricius

b. Scutellum reddish or faintly reddish on posterior margin; hind femora usually reddish

..... similis Macquart

19. a. Palpi, pleurae, and costal cell deep yellow .....quinquevittatus Wiedemann

b. Palpi and pleurae grayish or white; costal cell deeply colored .....20 20

20. a. Abdomen rather broadly reddish laterally; pleurae contrasting rather sharply with dark thoracic dorsum; large eye facets reaching occipital border with little reduction in size .....fuscicostatus Hine

b. Abdomen narrowly reddish laterally; dark gray pleurae not sharply contrasting with thoracic dorsum; small eye facets extending upward along eye margin nearly reaching ocellar area

21.(16)a. Costal cell brown or dark yellow ..... mularis Stone

b. Costal cell hyaline or pale yellow $\ldots .22$ $\ldots .23$

22. a. Third antennal segment sharply bicolored, basal plate orange, annuli black

b. Third antennal segment uniformly orange-brown ..... longiusculus Hine ..... zythicolor Philip

23. a. Hair and pollen of pleurae and face yellow; area of large and small eye facets scarcely differentiated

....ffulvulus Wiedemann

b. Hair and pollen of pleurae and face pale; large and small eye facets distinctly differentiated

24. a. Third antennal segment entirely orange; long hairs on dorsum of thorax yellow

.....pallidescens Philip

b. Third antennal segment with at least annuli black; long hairs on dorsum of thorax gray to black

25. a. Costal cell hyaline; short recumbent hairs of thoracic dorsum gray; sublateral abdominal spots gray 
b. Costal cell tinted; short hairs of thorax often yellowish; sublateral abdominal spots usually yellow or with a yellowish tint

26. a. Median abdominal stripe broad; face below eyes with many black hairs, beard yellowish white; second palpal segment stout, yellow brown with many black hairs

..... sagax Osten Sacken

b. Median abdominal stripe narrow; face with almost no black hairs, beard pale gray; second palpal segment relatively slender, pale yellowish white with few black hairs

.....sublongus Stone

27.(15)a. Frontal triangle bare and somewhat protuberant; abdominal triangles sometimes indistinct; small chunky species usually under $13 \mathrm{~mm}$

b. Frontal triangle pollinose

....nigripes Wiedemann

28. a. Abdomen with at least some sublateral spots

b. Abdomen with no distinct sublateral spots, although some segments may be paler laterally

29. a. First antennal segment swollen above; third antennal segment entirely black; eyes sometimes with sparse hairs

b. First antennal segment not swollen; third antennal segment variable; eyes bare

30. a. Larger species, over $16 \mathrm{~mm}$

b. Smaller species, under $16 \mathrm{~mm}$

31. a. Wing with a distinct spot at bifurcation

.....cymatophorus Osten Sacken

b. Wing mottled with brown, the spots not confined to cross veins or bifurcation; tergites 2-4 with posterior white bands nearly obliterating the median and sublateral spots, but the spots distinct on tergite 4

.....venustus Osten Sacken

32. a. Wing with very faint to no spot at bifurcation; fore tibia entirely black; sublateral spots very large, often crossing second and third segments; third antennal segment black .....marginalis Fabricius

b. Fore tibia paler at base; sublateral spots smaller; third antennal segment rarely entirely black

33. a. Moderate sized species, $14-15 \mathrm{~mm}$; second palpal segment yellow brown, about twice as long as wide; median triangles fairly large, sometimes crossing segment; sublateral spots reaching posterior margin on at least second segment; anterior portion of wing somewhat tinted 
b. Small species usually under $11 \mathrm{~mm}$; second palpal segment whitish, less than twice as long as thick; median triangles small, never crossing segment; sublateral spots rarely reaching posterior margins of segments; wing entirely hyaline

34. a. Tibiae same color as reddish-brown to brown femora or slightly paler basally; antennae yellowish, often with annulate portion somewhat darker; basal plate $2 \frac{1}{2}$ to 3 times as long as wide; occipital tubercle prominent and often projecting above level of eyes

.....pumilis Macquart

b. Tibia distinctly paler than dark femora, except apex of fore tibia which is dark; antennae uniformly dull brownish; basal plate about twice as long as wide; occipital tubercle inconspicuous and compressed, usually not reaching level of eyes

35. a. Eyes in life without stripes

b. Eyes in life with a single purple stripe .... sparus sparus Whitney .....sparus milleri Whitney

36.(28)a. Pale spot on second abdominal segment much smaller than those on third and fourth segments, or absent

b. Pale spot on second abdominal segment not markedly smaller than those on two following segments

37. a. Abdomen blackish with large white triangles not arising from bands on third to fifth segments; fore tibia bicolored .....trimaculatus Palisot de Beauvois

b. Not with this combination of characteristics; all tibiae dark reddish brown

38. a. Abdominal median triangles very small, not arising from bands; scutellum concolorous with thorax; area of large eye facets occupying about half of total eye area and sharply demarcated ..... superjumentarius Whitney

b. Abdominal triangles moderate size, often arising from bands; scutellum white pollinose; contrasting with dark thorax; area of large facets occupying about $2 / 3$ of total area but not sharply demarcated

39. a. Face and cheeks gray pollinose; abdominal stripes arise from pale bands which may cover basal half of third and fourth segments; venter with wide gray bands

..... molestus molestus Say

b. Face and cheeks mostly brown pollinose; abdominal bands if present very narrow on dorsum and venter .....molestus mixus Philip

40.(36)a. No spot at bifurcation

b. Bifurcation with a conspicuous spot [Contrasting marked species; abdominal triangles arising from bands] 
41. a. Large and small eye facets differ very little in size, not separated by a distinct line of demarcation; large species with very small median triangles and dark yellow legs and antennae

.....calens Linnaeus

b. Large eye facets distinctly set off from small facets; third antennal segment at least partly dark; size variable

42. a. Large species (over $20 \mathrm{~mm}$ ) with femora orange-brown or chestnut brown; first posterior cell not narrowed at wing base; excision of third antennal segment deep

b. Smaller species (under $20 \mathrm{~mm}$ ) with dark femora and paler tibiae; first posterior cell narrowed or closed at wing margin; excision of third antennal segment moderate

43. a. Legs almost uniformly brown, tarsi somewhat darker; genae brown; second palpal segment brown; abdomen uniformly dark brown with small median triangles

.....catenatus Walker

b. Middle and hind tibiae and base of fore tibiae paler than femora; second palpal segment yellow brown; abdomen reddish brown laterally with median triangles on narrow black stripe

.....novaescotiae Macquart

44. a. Median triangle crosses second abdominal segment; hind tibiae usually completely pale; large facets occupy about half of total area of compound eye

.....petiolatus Hine

b. Median triangle does not cross second abdominal segment; hind tibiae darkened at apex; large facets occupy about $2 / 3$ of total area of compound eye

.....melanocerus Wiedemann

45.(40)a. Legs rather uniformly yellowish to dark brown and fore tibiae not paler at base; antennae very slender; basal plate at least twice as long as its greatest width, narrower than height of first antennal segment and equal in length to annulate portion; larger species (over $20 \mathrm{~mm}$ )

.....turbidus Wiedemann

b. Legs with femora darker than tibiae and fore tibiae paler at base ..... 46

46. a. Pale median abdominal triangles conspicuous; middle femora often brownish; wing membrane lightly tinted

.....sulcifrons Macquart

b. Pale median abdominal triangles obsolete but with heavy median black spots; all femora deep black; wing heavily tinted, especially anteriorly 


\section{Tabanus abdominalis Fabricius}

There is some confusion about the identity of this species, which belongs to the abdominalis-sulcifrons complex. According to Pechuman (1954), $T$. abdominalis approaches $T$. sulcifrons but has a very narrow frons, closed posterior cell, no abdominal triangles, and wholly black femora. Among the surrounding states, it has been reported from PA, VA, $K Y$, and elsewhere from NE to MA, south to TX and FL. The complex is in need of revision, and older records should be confirmed. T. abdominalis should occur in West Virginia but has not yet been found.

Tabanus americanus Forster

Seasonal Range-11-VII to 5-IX (21-VI to X).

Distribution-BERKELEY, Arden, 5-IX-78, KM, WVU. FAYETTE, New River, 2-VIII-76, JM, WVU. HAMPSHIRE, Grace, 14-VII-77, CC, WVDA. MERCER, Bluefield, 13-VIII-78, JWB, WVU. MINGO, 5 mi. N. Williamson, 19-VII-76, BD, WVU. NICHOLAS, Rd. to Cranberry Campground, 11-VII76, BD, WVU.

This is the largest of the Tabanidae, but fortunately for livestock it does not occur in large numbers. These large blood feeders were observed to fly slowly and often alight or attempt to alight on man, the sides of a gold colored truck, and a large black raft traveling down the New River. T. americanus occurs in all of the contiguous states and probably throughout West Virginia.

Tabanus aranti Hays

This species has been collected in VA, PA, and TN. T. aranti is not easily distinguished from $T$. colon (originally described by Stone as T. atripennis and placed as a variety of $T$. nigrescens), which now appears to be a more western species. All of Stone's eastern specimens studied by Pechuman and Fairchild are aranti (pers. com., Pechuman). It has not been reported from West Virginia.

Tabanus atratus atratus Fabricius

Seasonal Range-26-V to 16-IX (14-IV to 2-XII). Distribution-BERKELEY, 7-VIII-77, RD, WVU. FAYETTE, Rainelle, 1-VIII-77, TK, WVU. HAMPSHIRE, Grace, 8-VI-76, WN and KE, WVDA. HARDY, 3-VIII-66, RM, WVU. MONONGALIA, Morgantown, 29-VIII-72, LB, WVU. MONROE, Wayside, 15-VIII-77, JWB, JWB. PRESTON, Arthurdale, 26-VIII-78, RS, WVU.

This species is nearly as large as T. americanus but is completely black (sometimes with a bluish tint on the abdomen). It should occur throughout the state in low numbers and has been found in all of the contiguous states.

\section{Tabanus calens Linnaeus}

Seasonal Range-3-VIII to 16-IX (19-VII to 1-X).

Distribution-BERKELEY, Sleepy Creek Publ.
Hunt. and Fish. Area, 3-VIII-75, BD, WVU. BRAXTON, Kanawha Run-Sutton Lk., 10-VIII-78, LB, WVU. CABELL, Nine Mile Rd., 13-VIII-76, BD, WVU. HAMPSHIRE, Capon Bridge, 31-VII-75, PV, WVDA. JEFFERSON, Shannondale, 2-VIII-77, JH, WVDA. LINCOLN, Big Ugly Publ. Hunt. Area, 2VIII-78, LB, WVU. MINERAL, N. Hanks Mem., 16VIII-77, LB, WVU. SUMMERS, Pipestem St. Pk., 16-IX-75, JH, WVDA. WETZEL, 2-IX-73, FP, WVU.

This late season species is widely distributed in small numbers in West Virginia and in the surrounding states.

Tabanus catenatus Walker

Seasonal Range-7-VIII to 12-VIII, (17-VI to 12-X). Distribution-MONONGALIA, 12-VIII, WVU. MONROE, Hollywood, 7-VIII-77, JH, WVDA (“BLT").

This species is not numerous throughout its range. Of the contiguous states, a few records are known from MD, PA, and VA.

Tabanus cymatophorus Osten Sacken

Seasonal Range-4-VIII ("July").

Distribution-HAMPSHIRE, Grace, 4-VIII-77, CC, WVDA, and LLP.

This is a very local species not commonly encountered. It is also known from MD and KY, the former being a single county record.

Tabanus fairchildi Stone

Seasonal Range-26-V to 13-VIII.

Distribution-BROOKE, Bethany, 10-VII-75, JH, WVDA. CABELL, Nine Mile Rd., 13-VIII-76, BD, WVU. HAMPSHIRE, Grace, 26-V-77, CC, WVDA. WETZEL, Lewis Wetzel Publ. Hunt. Area, BD, WVU.

Philips' catalog (1947) reported this species from all of the neighboring states, and it should occur throughout West Virginia in low numbers.

Tabanus fulvulus Wiedemann

Seasonal Range-15-VI to 8-VIII (4-VI).

Distribution-BERKELEY, Sleepy Creek Publ. Hunt. and Fish. Area, 2-VIII-75, BD, WVU. HAMPSHIRE, Capon Bridge, 15-VI-76, WN and KE, WVDA. HARDY, Warden Lk., 24-VII-76, BD, WVU. MINERAL, New Creek, 25-VI-76, BD, WVU. MORGAN, Cherry Run, 17-VII-78, CC, WVDA. PENDLETON, Ft. Seybert, 15-VII-76, WN and KE, WVDA. Lewis Wetzel Publ. Hunt. Area, 18-VI-76, BD, WVU.

West Virginia records are among the northernmost reports for T. fulvulus, which occurs south of a line from PA to OK. It is found primarily at lower elevations in the state, characteristic of southern species at their northern range limits.

Tabanus fuscicostatus Hine

Of the contiguous states, only two specimens are known from VA and KY. This species is primarily 
southern and possibly occurs in southern West Virginia.

\section{abanus gladiator Stone}

This species is not common, especially in this area. It is not known to occur north of $\mathrm{MD}$, and its southern range spans from eastern TX to FL.

abanus lineola Fabricius

Seasonal Range-12-VI to 14-VIII (31-V to 31-VIII). Distribution-BARBOUR, 8-VII-75, BD, WVU. BERKELEY, Sleepy Creek Publ. Hunt. and Fish. Area, 2-VIII-75, BD, WVU. BRAXTON, Sutton Lk., 8-VII-75, BD, WVU. HAMPSHIRE, Grace, 7-VII-76, WN and KE, WVDA. HARDY, Warden Lk., 24-VII76, BD, WVU. KANAWHA, St. Albans, 8-VII-77, JH, WVDA. LEWIS, Jackson's Mill, 28-VII-75, JH, WVDA. MASON, McClintic Wildlife Sta., 7-VII-77, JH, WVDA. MONONGALIA, WVU Animal Husbandry Farm, 2-VII-75, BD, WVU. MONROE, Rt. 219, 12-VIII-75, BD, WVU. NICHOLAS, Craig, 12-VI-70, JH, WVDA. PRESTON, Reedsville Exp. Sta., 24-VII-75, BD, WVU. RANDOLPH, Gilman, 29-VI-76, PV, WVDA. RITCHIE, N. Bend St. Pk., 23-VI-78, JH, WVDA. SUMMERS, Pipestem St. Pk., 28-VII-76, TM, WVU. UPSHUR, Stonecoal, 27-VI77, PV, WVDA. WETZEL, Lewis Wetzel Publ. Hunt. Area, 18-VI-76, BD, WVU.

This species is known from all surrounding states and becomes quite numerous at times, especially in June and July. Specimens from West Virginia are all of the melanistic, narrow-fronted form, distinct from the lineola of the coast (Pechuman and Burton, 1969).

Tabanus longiusculus Hine

The northernmost record was taken in MD. No other records of this southern species are known from surrounding states. It may be present in West Virginia. Tabanus longus Osten Sacken

Seasonal Range-6-VII to 14-IX (2-VII).

Distribution-"West Va." 1933, det. Fairchild, HU. BERKELEY, Sleepy Creek Publ. Hunt. and Fish. Area, 2-VIII-75, BD, WVU. HAMPSHIRE, Capon Bridge, 24-VII-75, CC, WVDA. HARDY, Warden Lk., 24-VII-76, LB and BD, WVU. MORGAN, Cacapon St. Pk., 2-VIII-75, BD, WVU.

$T$. longus has been considered rare in its known range (PA south to TX and GA). This study, however, has produced more specimens and longer series than have been previously known to Pechuman. In fact, at BERKELEY (2-VIII-75) this species made up 30 percent of the Tabanus collected. Black light traps were also a successful collection method for Tabanus there, and half of the Tabanus collected were T. longus females. This is the first record of $T$. longus attracted to UV light. Male $T$. longus are unknown, and intensive collecting in the BERKELEY county area failed to produce specimens. However, many male and female specimens of the superficially similar T. sackeni were captured. $T$. longus records seem to be restricted to the northeastern part of West Virginia, but it is known from all of the neighboring states.

Tabanus marginalis Fabricius

Seasonal Range-1-VI to 29-VII (1-V)

Distribution-HANCOCK, Tomlinson Run St. Pk., 9-VI-76, JA, WVU. POCAHONTAS, Bartow, 27-VI77, LB, WVU. PRESTON, Cranesville Swamp, 12-VI65, PT, PT. RANDOLPH, Gilman, 1-VI-76, PV, WVDA. UPSHUR, Stonecoal Lk., 27-VI-77, PV, WVDA.

This is a northern species, which has been reported from PA, OH, and MD. Disjunct populations are also known from mountainous areas and swamps as far south as NC.

\section{Tabanus melanocerus Wiedemann}

This species occurs in MD, KY, PA, and in VA counties very close to West Virginia's easternmost and southernmost border lines. It is not considered a common species but may become locally abundant.

Tabanus molestus molestus Say

Seasonal Range-15-VI to 17-VIII (9-VI to 1-IX).

Distribution-HAMPSHIRE, Capon Bridge, 16-VII75, PV, WVDA. HARDY, Moorefield, 17-VIII-76, WN, WVDA. KANA WHA, St. Albans, 15-VI-78, JH, WVDA. McDOWELL, Panther St. For., 10-VII-77, LB, WVU. WEBSTER, Summer 78, DF, WVU.

This species is not numerous in West Virginia but has an extensive distribution from WI to $\mathrm{NJ}$ southward to TX and FL.

Tabanus molestus mixus Philip

This is a southern species known as far north as KY, VA, and MD. It should occur in West Virginia at lower elevations. The taxonomic status of this dark form of $T$. molestus is uncertain; it may prove to be a separate species.

\section{Tabanus mularis Stone}

This is another southern species which seems to find its northernmost range east of the Appalachian Mountains in MD. Additional records from VA and KY suggest the possible occurrence of $T$. mularis at lower elevations of West Virginia.

Tabanus nigrescens Palisot de Beauvois

Seasonal Range-6-VII to 30-VII (22-VI to 12-VIII) Distribution-HAMPSHIRE, Grace, 21-VII-77, CC, WVDA. HARDY, Warden Lk., 24-VII-76, LB, BD and PF, WVU. MINERAL, Junction, 6-VII-76, WN and KE, WVDA. MONONGALIA, WVU Animal Husbandry Farm, 7-VII-75, BD, WVU. LEWIS, Jackson's Mill, 30-VII-75, JH, WVDA.

This species is probably more common in the state than records now depict, although large populations most likely will not be found. It is known from all of the states contiguous to West Virginia.

Tabanus nigripes Wiedemann

Seasonal Range-10-VI to 16-VIII (5-VI).

Distribution-BERKELEY, Sleepy Creek Publ. 
Hunt. and Fish. Area, 2-VIII-75, BD, WVU. GRANT, Petersburg, 2-VI-75, JH, WVDA. HAMPSHIRE, Grace, 30-VI-77, CC, WVDA. HARDY, Old Fields, 6VII-76, KE and WN, WVDA. JEFFERSON, Shannondale, 2-VIII-77, JH, WVDA. MASON, McClintic Wildlife Sta., 7-VII-77, JH, WVDA. MINERAL, New Creek, 25-VI-76, BD, WVU. MONONGALIA, WVU Animal Husband ry Farm, 2VII-75, BD, WVU. NICHOLAS, 20-VI-75, BD, WVU. PRESTON, Cranesville Swamp, 10-VI-77, HT, HT. RANDOLPH, 16-VIII-76, PV, WVDA (specimen in poor condition). SUMMERS, Pipestem St. Pk., 28-VI-77, JH, WVDA.

This Tabanus is widely distributed throughout eastern North America but is not reported to be abundant. It should occur throughout West Virginia.

\section{Tabanus novaescotiae Macquart}

Seasonal Range-10-VIII to 10-IX

Distribution-POCAHONTAS, Cranberry Glades, 10-VIII-52, HW, USNM. RANDOLPH, 10-IX-76, PV, WVDA.

This is a northern species also known from VA. Philip (1947) published records from MD and DC under the synonym T. actaeon. However, Thompson (1967a, b) believes these MD and DC records actually refer to $T$. catenatus. The West Virginia specimens represent disjunct populations. In 1974 Burger collected the first $T$. novaescotiae larvae from sphagnum at Cranberry Glades and reared them to adults (Teskey and Burger, 1976).

Tabanus pallidescens Philip

Seasonal Range-1-VI to 28-VII (18-VIII).

Distribution-BRAXTON, Sutton Lk., 8-VII-75, BD, WVU. KANAWHA, St. Albans, 1-VI-78, JH, WVDA. RITCHIE, N. Bend St. Pk., 23-VI-78, JH, WVDA. SUMMERS, Pipestem St. Pk., 28-VII-76, TM, WVU. WETZEL, Lewis Wetzel Publ. Hunt. Area, 18-VI-76, BD and RL, WVU.

This is a southern horse fly reported as far north as $\mathrm{NJ}$ and MO. In West Virginia it is probably widely distributed but is not common.

Tabanus petiolatus Hine

This is another southeastern species, occurring from TX to FL and north to NJ along the coast. Inland records from MD and VA suggest that it may occur in West Virginia.

Tabanus proximus Walker

This is a very late season species (1-IX to $3-\mathrm{X}$ ), and is recorded as far north as $\mathrm{OH}, \mathrm{MD}, \mathrm{VA}$, and KY. It is not often encountered in its northern range but may occur in West Virginia at lower elevations.

Tabanus pumilus Macquart

Seasonal Range-25-V to 28-VII (11-V to $15-\mathrm{VIII})$. Distribution-BERKELEY, Allansville, 25-V-77, CC, WVDA. BROOKE, Bethany, 10-VII-75, JH, WVDA. GRANT, Mt. Storm, 20-VI, WVU. GREENBRIER, Clendinsville, 18-VI-76, JH, WVDA. HAMPSHIRE,
23-VI-76, PV, WVDA. KANAWHA, St. Albans, 17VI-77, JH, WVDA. MASON, McClintic Wildlife Sta., 7-VII-77, JH, WVDA. MINERAL, New Creek, 11VI-76, BD, WVU. MONONGALIA, Dent's Run, 17 VI-76, BD, WVU. OHIO, Bear Rocks Lk., 25-V-76, JH, WVDA. PRESTON, Arthurdale, 12-VI-78, PS, WVU. RANDOLPH, Gilman, 12-VI-76, PV, WVDA. RITCHIE, North Bend St. Pk., 22-VI-77, LB, WVU. SUMMERS, PIPESTEM St. Pk., 14-VI-75, BD, WVU.

T. pumilus is widely distributed in West Virginia and the surrounding states. It is similar to $T$. sparus milleri in habits but is not quite as abundant.

Tabanus quinquevittatus Wiedemann

Seasonal Range-17-V to $10-\mathrm{IX}$; most common in VI and VII.

Distribution-BERKELEY, Sleepy Creek Publ. Hunt. and Fish. Area, 25-VII-76, BD, WVU. BRAXTON, Kanawha Run-Sutton Lk., 16-VIII-78, LB, WVU. BROOKE, Bethany, 10-VII-75, JH, WVDA. GILMER, Cedar Ck. St. Pk., 4-VI-77, LB, WVU. GRANT, Petersburg, 2-VII-75, JH, WVDA. HAMPSHIRE, 2 mi. E. Capon Bridge, 3-VII-75, BD, WVU. HARDY, Warden Lk., 24-VII-76, LB and BD, WVU. JACKSON, Millwood, 22-VII-75, JH, WVDA. JEFFERSON, 10-VI-77, RD, WVU. KANAWHA, St. Albans, 10-VII-77, JH, WVDA. LEWIS, Jackson's Mill, 28-VII-75, JH, WVDA. LINCOLN, Garrets Bend, 12-VII-77, KH, WVDA. MARSHALL, Dallas, 6-VIII-76, GL, WVDA. MASON, McClintic Wildlife Sta., 7-VII-77, JH, WVDA. MERCER, Bluefield, 31-VII-77, JWB, JWB. MINERAL, New Creek, 11-VI-76, BD, WVU. MONONGALIA, WVU Animal Husbandry Farm, 2VII-75, BD, WVU. MONROE, Rt. 219, 11-VIII-75, BD, WVU. MORGAN, Cherry Run, 5-VII-78, CC, WVDA. OHIO, Bear Rocks Lk., 17-VIII-77, JH, WVDA. PENDLETON, German Valley, 16-VII-75, JH, WVDA. PRESTON, Reedsville Exp. Sta., 10VII-75, CS. RANDOLPH, Gilman, 22-VI-76, PV, WVDA. RITCHIE, N. Bend St. Pk., 23-VI-78, JH, WVDA. UPSHUR, Buckhannon, 12-VI-76, JH, WVDA. WETZEL, Lewis Wetzel Publ. Hunt. Area, 18-VI-76, BD, WVU.

$T$. quinquevittatus and $T$. nigrovittatus, its close relative in the coastal salt-marsh area, are known commonly as "green-heads." This species was reported from all of the surrounding states by Philip (1947), and it has been taken from all of West Virginia's geographic zones, being most abundant in the Eastern Panhandle. T. quinquevittatus is one of the more important pests of livestock in the state and is able to build up in high numbers. While most tabanid larvae are restricted to substrates in or adjacent to bodies of water, larvae of this species have been collected from low-lying areas in cultivated fields and pastures. Thus, this species has acquired a much larger breeding area. 
Tashiro and Schwardt (1953b) estimated that 19,360 potential blood feeding females could emerge from one acre of suitable breeding area. Females prefer feeding on the paunch, dewlap, and udder of cattle (Blickle, $1955)$ and they will readily attack people (Thompson 1967a, 1969).

Tabanus reinwardtii Wiedemann

Seasonal Range-27-VI to 9-VII (28-V to 26-VIII). Distribution-GREENBRIER, Greenbrier St. For., 9-VII-77, LB, WVU. HARDY, Moorefield, 30-VI-77, JH, WVDA. MONONGALIA, WVU Hort. Farm (found dead in a greenhouse), IX-75, BD, WVU.

T. reinwardtii adults are not commonly collected, although the larvae are relatively common. This species has been reported from all of the contiguous states and is probably evenly distributed throughout West Virginia.

Tabanus sackeni Fairchild

Seasonal Range-24-VI to 1-X (17-VI); most common in VIII.

Distribution-BERKELEY, Sleepy Creek Publ. Hunt. and Fish. Area, 2-VIII-75, BD, WVU. BRAXTON, Kanawha Run-Sutton Lk., 16-VIII-78, LB, WVU. BROOKE, Wellsburg, 7-VIII-77, RL, WVU. CABELL, Nine Mile Rd., 13-VIII-76, BD, WVU. GRANT, Greenland, 27-VII-78, CC, WVDA. GREENBRIER, Greenbrier St. For., 27-VIII-78, LB, WVU. HAMPSHIRE, Capon Bridge, 24-VI-75, CC, WVDA. HANCOCK, Chester, 15-VIII-78, JH, WVDA. HARDY, Lost River St. Pk., 23-VIII-56, KK, KK. JEFFERSON, Shannondale, 3-VIII-78, CC, WVDA. LEWIS, Jackson's Mill, 26-VII-77, JH, WVDA. LINCOLN, Big Ugly Publ. Hunt. Area, 2VIII-78, LB, WVU. MARION, Bunner's Ridge, 4VIII-77, LB, WVU. MARSHALL, Girl Scout Camp, 6-VIII-77, GL, WVU. MASON, Chief Cornstalk Publ. Hunt. Area, 2-VIII-78, LB, WVU. MINERAL, Junction, 27-VII-76, WN and KE, WVDA. MONONGALIA, WVU Hort. Farm, 21-VII-75, LB, WVU. MORGAN, Orleans Cross Roads, 7-IX-72, JB, JB. NICHOLAS, Summersville, 4-VII-70, JH, WVDA. OHIO, Wheeling, 14-VIII-74, JW, WVDA. PENDLETON, Ft. Seybert, 29-VII-76, WN and KE, WVDA. POCAHONTAS, Boyer, 5-VIII-76, WN and KE, WVDA; PUTNAM, Hurricane, 11-VIII-77, JH, WVDA. RANDOLPH, 10-IX-76, PV, WVDA. SUMMERS, Pipestem St. Pk., 13-VIII-75, JH, WVDA. WOOD, 26-VII-75, BD, WVU. WEBSTER, 8-VIII-78, DF, WVU. WETZEL, Proctor District, 25VII-75, EE, EE.

This abundant species may be the most important pest during the later part of the season. It is found throughout West Virginia and contiguous states. Adults have crepuscular and nocturnal habits, both sexes being readily attracted to black light traps.

Tabanus sagax Osten Sacken

Seasonal Range-23-VII to 2-VIII (27-VI).
Distribution-BERKELEY, Sleepy Creek Publ. Hunt. and Fish. Area, 2-VIII-75, BD, WVU.

This fly is not often collected, but is widely distributed in the eastern United States. Further collecting in the lower western areas of the state may produce more specimens.

Tabanus similis Macquart

Seasonal Range-28-V to 9-VIII.

Distribution-HAMPSHIRE, Grace, 23-VI-76, WN and KE, WVDA. MINERAL, New Creek, 25-VI-76, BD, WVU. MONONGALIA, Dent's Run, 28-V-75, BD, WVU. NICHOLAS, 2-VI-70, JH, WVDA. PENDLETON, Seneca Campground, 23-VI-76, BD, WVU. PRESTON, Eglon, 1-VII-75, RW', WVU. RANDOLPH, Gilman, 12-VI-76, PV, WVDA. SUMMERS, Pipestem St. Pk., 14-VI-76, BD, WVU.

Pechuman (1973) states that the southern limit of this species in eastern U.S. occurs in VA and KY. It is widespread in West Virginia, seemingly restricted to the hilly and mountainous regions.

Tabanus sparus sparus Whitney

This species may be numerous in some localities, but it has a spotty distribution. It is known from PA, MD, VA, NC, and IN, and may eventually be found in West Virginia.

Tabanus sparus milleri Whitney

Seasonal Range-26-V to 29-VIII (15-V)

Distribution-BERKELEY, Sleepy Creek Publ. Hunt. and Fish. Area, 2-VIII-75, BD, WVU. GRANT, Greenland, 13-VII-78, CC, WVDA. HAMPSHIRE, Capon Bridge, 25-VI-75, CC, WVDA. HARDY, Lost River St. Pk., 6-VII-55, KK, KK. KANAWHA, St. Albans, 5-VI-76, JH, WVDA. MASON, McClintic Wildlife Sta., 7-VII-77, JH, WVDA. MINERAL, New Creek, 11-VI-76, BD, WVU. MONONGALIA, WVU Animal Husbandry Farm, 7-VII-75, BD, WVU. MORGAN, Cherry Run, 13-VI-78, CC, WVDA. PENDLETON, Ft. Seybert, 22-VII-76, WN and KE, WVDA. RITCHIE, N. Bend St. Pk., 23-VI-78, JH, WVDA. SUMMERS, Pipestem St. Pk., 28-VI-77, JH, WVDA. WOOD, 17-VI-75, TM, WVU.

This is the more common of the two forms of $T$. sparus, and has been collected in all of the neighboring states. Most of the records are from the Eastern Panhandle, where it seems to be more numerous. It attacks man readily in much the same manner as do aggressive Chrysops. It also occurs in large numbers and is thus considered to be the most annoying of the synanthropic horse flies.

Tabanus stygius Say

This tabanid is not commonly collected, but it has a wide distribution covering the eastern United States. Having been recorded in all of the neighboring states except KY, it will probably be found in West Virginia.

Tabanus sublongus Stone

Seasonal Range-1-VIII to 9-IX.

Distribution-HARDY, Lost River St. Pk., 22-VIII- 
56, KK, KK and LLP. HAMPSHIRE, Capon Bridge, 13-VIII-75, PV, WVDA. MORGAN, Orleans Cross Roads, 7-IX-72, JB, JB.

$T$. sublongus records are restricted to the eastern side of the Appalachians in West Virginia. However, it has been collected in $\mathrm{OH}, \mathrm{KY}$ and, in the south, it has been reported as far west as $\mathrm{OK}$.

Tabanus subniger Coquillett

This species has been found primarily north of the state, but it has been reported from $\mathrm{PA}$ and $\mathrm{OH}$ counties very close to the northern tips of West Virginia's Eastern and Northern Panhandles. This tabanid is rare throughout its range but probably occurs within the state's borders.

Tabanus subsimilis subsimilis Bellardi

Seasonal Range-14-V to 14-IX.

Distribution-BERKELEY, Arden, 29-VII-78, KM, WVU. BROOKE, Bethany, 10-VII-75, JH, WVDA. HAMPSHIRE, Grace, 4-VIII-76, WN and KE, WVDA. HANCOCK, Newell, 7-VIII-77, RL, WVU. HARDY, Moorefield, 5-VIII-77, LB, WVU. HARRISON, Clarksburg, 15-VII-74, JH, WVDA. KANAWHA, St. Albans, 10-VII-77, JH, WVDA. LEWIS, Jackson's Mill, 28-VII-75, JH, WVDA. MASON, Rt. 2, 4-VII-76, BD, WVU. MINERAL, New Creek, 11-VI-76, BD, WVU. MONONGALIA, Morgantown, 18-VIII-72, LB, WVU. MONROE, Hollywood, 30-VIII-76, EB, WVDA. NICHOLAS, Summersville, 4-VII-70, JH, WVDA. PENDLETON, 4-IX-77, JV, WVU. PRESTON, Cranesville Swamp, 18-VIII-76, BD, WVU. RANDOLPH, Elkins, 20VIII-68, WF, WF. WETZEL, Lewis Wetzel Publ. Hunt. Area, 18-VI-76, BD, WVU. WOOD, 16-VI-71, LB, WVU.

T. subsimilis is widely distributed but not very abundant in West Virginia. This species responds well to black light traps, suggesting crepuscular or nocturnal behavior.

Tabanus sulcifrons Macquart

Seasonal Range-4-VII to 26-X (10-VI); most common in VII and VIII.

Distribution-BERKELEY, Sleepy Creek Publ. Hunt. and Fish. Area, 2-VIII-75, BD, WVU. HAMPSHIRE, Capon Bridge, 13-VIII-75, PV, WVDA. HARDY, Lost River St. Pk., 22-VIII-56, KK, KK. JACKSON, Millwood, 22-VII-75, JH, WVDA. JEFFERSON, Kearneysville, 26-X-76, RB, WVU. KANAWHA, Charleston, 20-VII-75, CP, WVU. LEWIS, Jackson's Mill, 28-VII-75, JH, WVDA. LINCOLN, Garrets Bend, 16-VIII-77, KH, WVDA. MASON, McClintic Wildlife Sta., 7-VII-77, JH, WVDA. MONONGALIA, Cooper's Rock, 20VII-59, JHH, WVU. MONROE, Near Wayside, 26VII-76, TM, WVU. PRESTON, Little Laurel Run, 2VIII-77, JA, WVU. RITCHIE, Cairo, 1930, JCB, CU. ROANE, Spencer, 4-VII-75, RJ, CU. SUMMERS, Pipestem St. Pk., 13-VIII-75, JH, WVDA. TAYLOR,
Grafton, 29-VII-51, CM. WETZEL, Proctor District, 25-VII-75, EE, EE. WIRT, Craig, 2-VIII-69, JH, WVDA. WOOD, 26-VII-75, PC, WVU.

This species comprises part of the sulcifronsabdominalis compex, which is in need of revision. Material now described as $T$. sulcifrons may actually represent several species, and distribution records may be altered in the future. T. sulcifrons occurs throughout the eastern United States. Although $T$. sulcifrons is not as numerous as some of the common smaller tabanids, its large size should be taken into consideration when evaluating its importance to livestock. It has a noisy approach that tends to frighten animals, and when it bites, it takes much blood ( 0.34 cc) and leaves large punctures (Tashiro and Schwardt, 1953). Immatures, like those of $T$. quinquevittatus, can survive in dry soil, which accounts for its abundance and wide distribution.

Tabanus superjumentarius Whitney

Seasonal Range-5-VI to 12-VIII (5-V).

Distribution-BROOKE, Bethany, 10-VII-75, JH, WVDA. KANAWHA, St. Albans, 5-VI-77, JH, WVDA. MASON, McClintic Wildlife Sta., 7-VII-77, JH, WVDA. MONONGALIA, $5 \mathrm{mi}$. S. Core, 16-VI76, BD, WVU. RANDOLPH, Gilman, 29-VI-76, PV, WVDA. RITCHIE, N. Bend St. Pk., 23-VI-78, JH, WVDA. SUMMERS, Pipestem St. Pk., 28-VI-77, JH, WVDA. WEBSTER, Cranberry Campground, 11VII-76, BD, WVU. WETZEL, Lewis Wetzel Publ. Hunt. Area, 18-VI-76, BD, WVU.

Although this species is not reported from KY, it occurs in all of the other neighboring states. In West Virginia, it has not been collected in the Eastern Panhandle, but it should occur there.

Tabanus trimaculatus Palisot de Beauvois

Seasonal Range-8-VI to 4-VIII (15-V to 18-VIII).

Distribution-HAMPSHIRE, Grace, 4-VIII-76, WN and KE, WVDA. HARDY, 2 mi. S. Moorefield, 4VII-77, LB, WVU. MASON, McClintic Wildlife Sta., 7-VII-77, JH, WVDA. MONONGALIA, Joe's Run, 8-VI-76, LB, WVU. PENDLETON, Seneca Campground, 23-VI-76, BD, WVU. RANDOLPH, Gilman, 15-VI-76, PV, WVDA.

This attractive tabanid may become locally abundant. It should be found throughout West Virginia as it has been reported from all of the surrounding states.

Tabanus turbidus Wiedemann

This is another southern tabanid which may occur in the state. The type specimen was collected in KY, and it ranges from extreme south to LA and FL. No records have been reported from other states contiguous to West Virginia.

Tabanus venustus Osten Sacken

This species is considered rare within its range. Pechuman knows of specimens from western $\mathrm{OH}$ and 
central KY, leading one to suspect its occurrence in West Virginia.

Tabanus vivax Osten Sacken

Seasonal Range-10-VI to 18-VIII

Distribution-POCAHONTAS, Cranberry Glades, 15-VIII-52, HW, USNM. PRESTON, Cranesville Swamp, 18-VIII-76, BD, WVU. WEBSTER, Cranberry Campground, 20-VI-75, BD, WVU.

This species is not commonly collected, and West Virginia's mountains mark the southern extreme of its

\section{LITERATURE CITED}

Adkins, T. R., W. B. Ezell, Jr., D. C. Sheppard, and M. M. Askey, Jr. 1972. A modified canopy trap for collecting Tabanidae (Diptera). J. Med. Entomol. 19:183-185.

Allen, W. A. and L. L. Pechuman. 1975. New distribution records of 38 species of Virginia tabanids (Diptera: Tabanidae). USDA Coop. Econ. Insect Rpt. 25:305-309.

1976. New geographical and seasonal listribution records of fifty-three species and subspecies If Virginia tabanids (Diptera: Tabanidae). USDA Coop. Plant Pest Rpt. 1:853-858.

1977. New geographical and seasonal listribution records for forty-four species and subspecies if tabanids from Virginia, Tennessee and West Virginia Diptera, Tabanidae). USDA Coop. Plant Pest Rpt. :887-891.

Inthony, D. W. 1960. Tabanidae attracted to a U.V. ight trap. Fla. Entomol. 43:77-80.

lickle, R. L. 1955. Observations on habits of Tabanidae. thio J. of Sci. 55:308-310.

borror, D. J., D. M. Delong and C. A. Triplehorn, 1976. In Introduction to the Study of Insects. Holt, Rinehart and Winston, N.Y. 812 pp.

Irennan, J. M. 1935. The Pangioniinae of nearctic Imerica (Diptera: Tabanidae). Univ. Kansas Sci. Bull. 2:249-401.

Jimley, C. S. 1922. Additional data on North Carolina rabanidae, Bombyliidae, and Tachinidae (Diptera). Entomol. News. 33:230-232.

and F. Sherman. 1904. List of the labanidae (horse flies) of North Carolina. Entomol. Vews 15:270-275.

Burnett, A. M., C. V. Covell, Jr. and L. L. Pechuman. 978. The horse flies and deer flies of Kentucky: New state icords and revised annotated checklist (Diptera: labanidae). Entomol. News 89:197-200.

hvvala, M., L. Lyneborg and J. Moucha. 1972. The horse lies of Europe (Diptera, Tabanidae). Entomol. Soc. of iopenhagen. Copenhagen, 499 pp. range. In the neighboring states, $\mathrm{PA}$ and $\mathrm{MD}$ records are known. All of the West Virgina specimens were taken near sphagnum bogs.

Tabanus zythicolor Philip

This tabanid was originally described from NC; it is rarely found in collections and has a reported range from NJ to LA and FL. Of the contiguous states, only coastal records from VA exist. It has not yet been found in West Virginia.

Clark, A. H. and L. F. Clark. 1951. The butterflies of Virginia. Smithsonian Misc. Coll. 116:239 pp.

Core, E. L. 1966. Vegetation of West Virginia. McClain Printing Co., Parsons, West Virginia, 217 pp.

Daecke, E. 1907. Annotated list of the species of Chrysops occurring in New Jersey and descriptions of two new species. Entomol. News 18:139-146.

Ezell, W. B., D. C. Sheppard, T. R. Adkins, Jr. and L. L. Pechuman. 1974. An annotated list of Tabanidae (Diptera) of South Carolina. J. Ga. Entomol. Soc. 9:9199.

Fairchild, G. B. 1969. Climate and the phylogeny and distribution of Tabanidae. Bull. Entomol. Soc. Amer. 15:7-11.

1975. The North American species of Silvius (Silvius) Meigen (Diptera, Tabanidae). Fla. Entomol. 58:24-27.

1976-1978. Department of Entomology. University of Florida, Gainesville. Personal communication.

Frost, S. W. 1953. Tabanidae attracted to light. Ann. Entomol. Soc. Amer. 46:124-125.

and L. L. Pechuman. 1958. The Tabanidae of Pennsylvania. Trans. Amer. Entomol. Soc. 84:169-215.

Goodwin, J. T. 1972. Immature stages of some Eastern nearctic Tabanidae (Diptera). I. Introduction and the genus Chrysops Meigen. J. Ga. Entomol. Soc. 7:98-109.

1973a. Ibid. II. Genera of the tribe

Diachlorini. J. Ga. Entomol. Soc. 8:5-11.

1973b. Ibid. III. The genus Tabanus Linn. J. Ga. Entomol. Soc. 8:82-99.

1973c. Ibid. IV. The genus Merycomyia, J. Tenn. Acad. Sci. 48:115-118.

1976a. Ibid. VII. Haematopota Meigen and Whitneyomyia Bequaert plus other Tabanini. Fla. Entomol. 59:369-390. 
1976b. Notes on some "rare" eastern nearctic Tabanidae (Diptera): State records and hostparasite relationship for other species. Fla. Entomol. 59:63-66.

Hacker, J. D., L. Butler and L. L. Pechuman. 1979. New geographical distribution records for forty-four species and subspecies of tabanids in West Virginia. USDA Coop. Plant Pest Rpt. 4:220-224.

Hanec, W. and G. K. Bracken. 1964. Seasonal and geographic distribution of Tabanidae (Diptera) in Manitoba based on females captured in traps. Can. Entomol. 96:1362-1369.

Hine, J. S. 1903. Tabanidae (Diptera) of Ohio. Ohio State Acad. Sci. Special Papers 5:1-63.

1906. Habits and life histories of some flies of the family Tabanidae. Tech. Ser. Bull. Entomol. U. S. 12:19-38.

American Tabanidae. Ohio Nat. 12:513-516.

Howell, D. E., C. E. Sanborn, L. E. Rozenboom, G. W. Stiles and L. H. Moe. 1941. The transmission of anaplasmosis by horse flies (Tabanidae). Oklahoma Agric. and Mech. College, Agric. Exp. Sta. Tech. Bull. No. T-11. $22 \mathrm{pp}$.

James, M. T. and R. F. Harwood. 1969. Herm's Medical Entomology. The MacMillan Co., London, 484 pp.

Jones, C. M. and D. W. Anthony. 1964. The Tabanidae of Florida (Diptera). Agric. Res. Ser., U.S.D.A. Tech. Bull. No. 1295, Washington, D.C., 85 pp.

Knowlton, G. F. and J. A. Rowe. 1934. Preliminary studies of insect transmission of equine encephalomyelitis. Utah Acad. Sci., Arts and Letters 11:267-270.

Krinsky, W. L. 1976. Review article-animal disease agents transmitted by horse flies and deer flies (Diptera: Tabanidae). J. Med. Entomol. 13:225-275.

MacCreary, D. 1940. Report on the Tabanidae of Delaware. Univ. Del. Agric. Exp. Sta., Bull. No. 226, Newark, Del., 41 pp.

1963. Additional notes on Diptera (Tabanidae) from Delaware. Bull. Brooklyn Entomol. Soc. 58:97-98.

Mackerras, I. M. 1954. The classification and distribution of Tabanidae (Diptera). General Review Aust. J. Zool. 2:431-454.

Matthysse, J. G., D. E. Mock and H. R. Netherton. 1974. Seasonal flight period and relative abundance of Tabanidae (Diptera) near Ithaca, New York. Ann. Entomol. Soc. Amer. 67:158-166.

McAtee, W. L. and W. R. Walton. 1918. District of
Columbia Diptera: Tabanidae. Proc. Entomol. Soc. Wash. 20:188-206.

Oldroyd, H. 1964. The Natural History of Flies. W. W. Norton and Co., Inc., N. Y., 324 pp.

Pechuman, L. L. 1954. Seasonal distribution of some Tennessee Tabanidae (Diptera). Bull. Brooklyn Entomol. Soc. 49:128-130.

1958. Some comments on Tabanus longisculus Hine (Diptera, Tabanidae). Bull. Brooklyn Entomol. Soc. 53:74-75.

1960. Some new and little known North American Tabanidae (Diptera). Can. Entomol. 92:793-799.

1972. The horse flies and deer flies of New York. (Diptera, Tabanidae). Search Agric. 2:1-72.

1973. Horse flies and deer flies of Virginia (Diptera, Tabanidae). The insects of Virginia: Part 6. Research Div. Bull. 81, VPI and State University.

1974. Two new tabanids from southeastern United States (Diptera). J. New York Entomol. Soc. 82:183-188.

1975. Checklist of nearctic Tabanidae north of Mexico. Unpublished manuscript.

and J. J. S. Burton. 1969. Seasonal distribution of Tabanidae (Diptera) at Texas Hollow, New York in 1968. Mosq. News 29:216-220.

and H. J. Teskey. 1967. A new eastern nearctic Chrysops (Diptera, Tabanidae). Can. Entomol. 99:645-650.

Philip, C. B. 1928. Methods of collecting and rearing the immature stages of Tabanidae (Diptera). J. Parasit. 14:243-253.

1931. The Tabanidae (horse flies) of Minnesota with special reference to their biology and taxonomy. Univ. Minn. Agric. Exp. Sta. Tech. Bull. 80:1132.

1941. Comments on the supra-specific catagories of nearctic Tabanidae (Diptera). Can. Entomol. 73:2-14.

1947. A catalog of the blood sucking fly family Tabanidae (horse flies and deer flies) of the nearctic region north of Mexico. Amer. Mid. Nat. 37:257325.

1950a. New North American Tabanidae (Diptera). Part II, Tabanidae. Ann. Entomol. Soc. Amer. 43:115-122.

1950b. Corrections and addenda to a catalog of nearctic Tabanidae. Amer. Mid. Nat. 43:430437. 
1965. Family Tabanidae. In: Stone, A., C. W. Sabrosky, W. W. Wirth, R. H. Foote, and J. R. Coulson (Eds.). A catalog of Diptera of North America. Agric. Handbook No. 276, U.S.D.A.:319-342.

1966. New North American Tabanidae. Part XVIII, new species and addenda to a nearctic catalog. Ann. Entomol. Soc. Amer. 59:519-527.

H. V. Weems, Jr. and G. B. Fairchild. 1973. Notes on eastern nearctic Haematopota, Merycomia, and Chrysops, and description of male of $C$. zinzalus (Diptera: Tabanidae). Fla. Entomol. 56:339-346.

Roberts, R. H. 1970a. Tabanidae collected in a malaise trap baited with CO2. Mosq. News 30:52-53.

Roberts, R. H. 1970b. Color of malaise trap and the collection of Tabanidae. Mosq. News 30:567-571.

1975. Altitude distribution of Tabanidae as determined by malaise trap collection. Ann. Meet. Entomol. Soc. of Amer., Nov. 30-Dec. 4, New Orleans, Louisiana.

and R. J. Dicke. 1974. The biology and taxonomy of some immature nearctic Tabanidae (Diptera). Ann. Entomol. Soc. Amer. 57:31-40.

W. A. Pund, H. F. McCrory, J. W. Scales and J. C. Collins. 1969. Culicidae and Tabanidae as potential vectors of anaplasmosis in Mississippi. Ann. Entomol. Soc. Amer. 62:863-868.

Schwardt, H. H. 1936. Horseflies of Arkansas. Univ. Kansas Agric. Exp. Sta. Bull. 332:1-66.

Snoddy, E. L. 1970. Trapping deerflies with colored weather balloons. J. Ga. Entomol. Soc. 5:207-209.

Stein, C. D., J. C. Lotz and L. O. Mott. 1942. Transmission of equine infectious anemia by the stable fly Stomoxys calcitrans, the horse fly $T$. sulcifrons (Macquart) and by injection of minute amounts of virus. Am. J. Vet. Res. 3:183-193.

Stone, A. 1930. The bionomics of some Tabanidae (Diptera). Ann. Entomol. Soc. Amer. 23:261-304.

1938. The horseflies of the subfamily Tabaninae of the nearctic region. U.S.D.A. Misc. Pub. No. 305, Washington, D.C., 171 pp.

Tashiro, H. and H. H. Schwardt. 1949. Biology of the major species of horse flies of central New York. J. Econ. Entomol. 42:269-272.

1953a. Some natural enemies of horse flies in New York. J. Econ. Entomol. 46:680-681. 1953b. Biology of horse flies in New York. J. Econ. Entomol. 46:813-822.

Teskey, H. J. 1969. Larvae and pupae of some eastern
North American Tabanidae (Diptera). Memoirs Entomol. Soc. Canada, No. 63, 147 pp.

and J. F. Burger. 1976. Further larvae and pupae of eastern North American Tabanidae. Can. Entomol. 108:1092.

and A. W. Thomas. 1979. Identity of Hybomitra typhus and description of a new species previously confused with it. Can. Entomol. 3:343.

Thompson, P. H. 1967a. Tabanidae of Maryland. Trans. Amer. Entomol. Soc. 93:463-519.

1967b. Addenda: The Tabanidae of Maryland. Proc. Entomol. Soc. Wash. 73:378-381.

Thompson, P. H. 1969. Collecting methods for Tabanidae. Ann. Entomol. Soc. Amer. 62:50-57.

1971. Tabanidae of Maryland, addenda (Diptera). Proc. Entomol. Soc. Wash. 73:378381 .

Thorsteinson, A. J., G. K. Bracken and H. Hanec. 1965. The orientation behavior of horse flies and deer flies (Tabanidae, Diptera). III. The use of traps in the study of orientation of tabanids in the field. Entomol. Exp. and Appl. 8:189-192.

and W. Tostowaryk.

1966. V. The influence of the number and inclination of reflecting surfaces on attractiveness to tabanids of glossy black polyhedra. Can. J. Entomol. 44:275-279.

Tidwell, M. A. 1973. The Tabanidae of Louisiana. Tulane Stud. Zool. Bot. 18:1-95.

and M. A. Tidwell. 1973. Larvae and pupae of five eastern North American Tabanus species (Diptera, Tabanidae). Ann. Entomol. Soc. Amer. 66:390398.

Townes, H. 1962. Design for a malaise trap. Proc. Entomol. Soc. Wash. 64:253-262.

Townsend, L. H. 1955. An annotated list of the Tabanidae collected in Kentucky. Entomol. News 66:6973.

U. S. Department of Agriculture. 1975. News ItemEquine infectious anemia. APHIS.

Webb, J. L. and R. W. Wells. 1924. Horse-flies: biologies and relation to western agriculture. U.S.D.A. Bull. 1218:1-36.

Wilson, B. H., N. P. Tugwell and E. C. Burns. 1966. Attraction of tabanids to traps baited with dry ice under field conditions in Louisiana. J. Med. Entomol. 3:148149.

Woodson, F. E. 1976. Division of Animal and Veterinary Sciences, WVU. Personal communication. 
[Blank Page in Original Bulletin] 


\section{THIS PAGE WAS NOT SCANNED OR OCRED}

